\title{
Multiple Landslide-Hazard Scenarios Modeled for the Oakland-Berkeley Area, Northern California
}

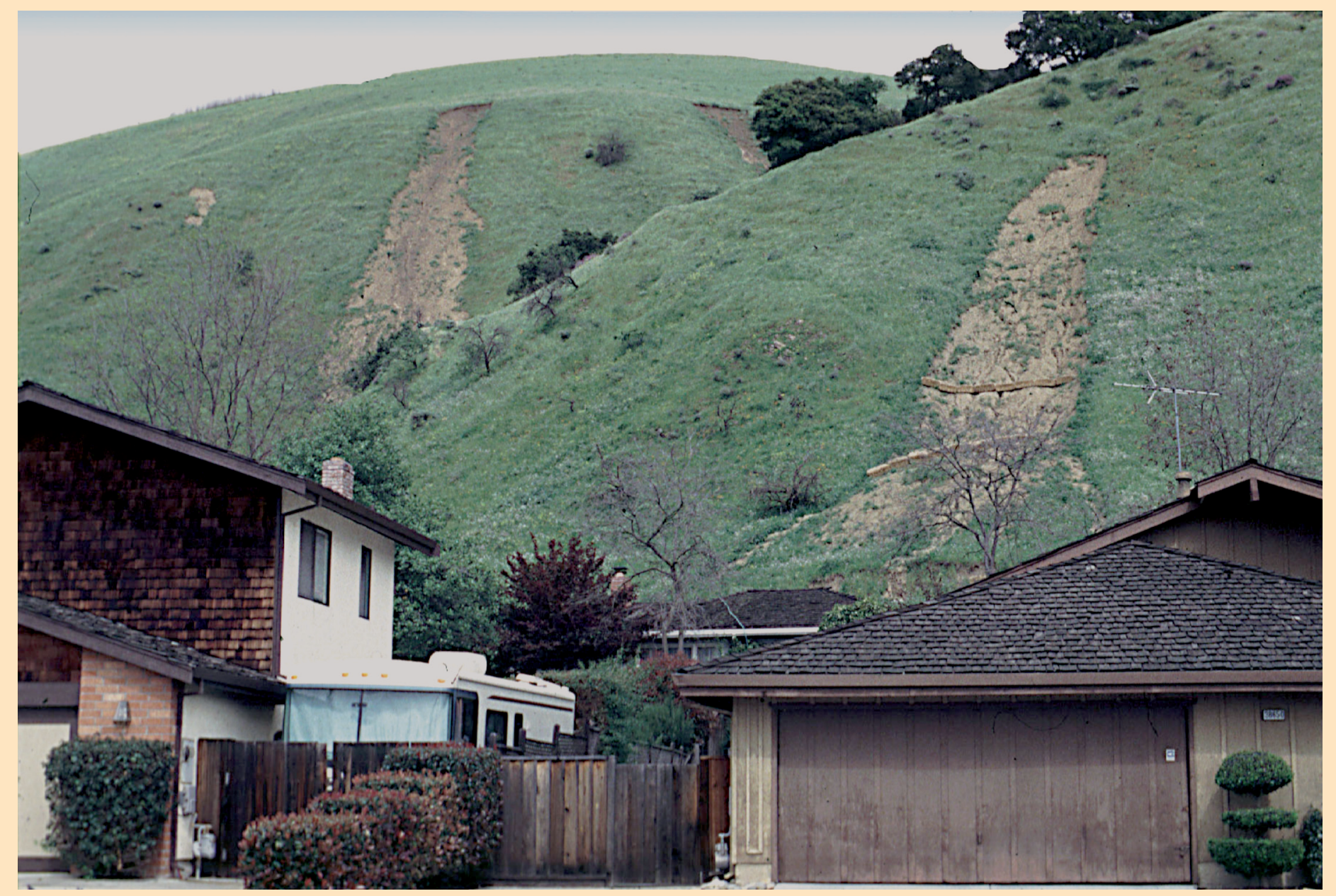

Scientific Investigations Report 2007-5196

U.S. Department of the Interior U.S. Geological Survey 


\section{Multiple Landslide-Hazard Scenarios Modeled for the Oakland-Berkeley Area, Northern California}

By Richard J. Pike and Russell W. Graymer, Editors

Scientific Investigations Report 2007-5196

U.S. Department of the Interior

U.S. Geological Survey 


\title{
U.S. Department of the Interior DIRK KEMPTHORNE, Secretary
}

\author{
U.S. Geological Survey \\ Mark D. Myers, Director
}

U.S. Geological Survey, Reston, Virginia: 2008 This report and any updates to it are available online at:
http://pubs.usgs.gov/sir/2007/5196/
For additional information write to:
U.S. Geological Survey
Box 25046, Mail Stop 421, Denver Federal Center
Denver, CO 80225-0046
Additional USGS publications can be found at:
http://www.usgs.gov/pubprod/
For more information about the USGS and its products:
Telephone: 1-888-ASK-USGS (1-888-275-8747)
World Wide Web: http://www.usgs.gov/
Any use of trade, product, or firm names in this publication is for descriptive purposes only and does not imply
endorsement by the U.S. Government.
Although this report is in the public domain, it may contain copyrighted materials that are noted in the text. Permission
to reproduce those items must be secured from the individual copyright owners.

\section{Cataloging-in-Publication data are on file with the Library of Congress}

Produced in the Western Region, Menlo Park, California

Manuscript approved for publication, 9/7/07

Text and Plates edited by Taryn A. Lindquist

Layout and design by Stephen L. Scott

FRONT COVER

Debris flows on San Francisco Bay region hillsides, triggered by the February 1998 storm.

Photograph by J.A. Coe, U.S. Geological Survey. 


\section{Contents}

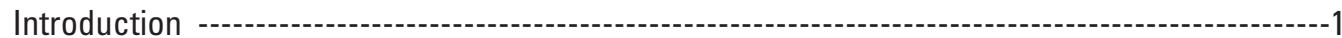

Russell W. Graymer

Chapter 1 Rainfall Thresholds for Landslide Activity, San Francisco

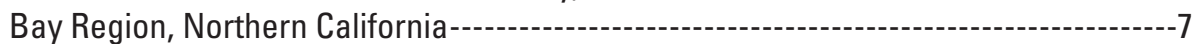

Raymond C. Wilson

Chapter 2 Susceptibility to Deep-Seated Landsliding Modeled for the Oakland-Berkeley

Area, Northern California---:- 15

Richard J. Pike and Steven Sobieszczyk

Chapter 3 Susceptibility to Shallow Landsliding Modeled for the Oakland-Berkeley Area,

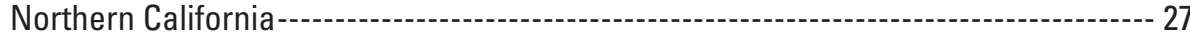

Kevin M. Schmidt and Steven Sobieszczyk

Chapter 4 Landslide Hazard Modeled for the Cities of Oakland, Piedmont, and Berkeley, Northern California, from a $M=7.1$ Scenario Earthquake on the Hayward Fault Zone

Scott B. Miles and David K. Keefer

Chapter 5 Synthesis of Landslide-Hazard Scenarios Modeled for the Oakland-Berkeley

Area, Northern California

Richard J. Pike

\section{Plates}

Plate 1 Susceptibility to Deep-Seated Landsliding Modeled for the Oakland-Berkeley Area, Northern California

Richard J. Pike, Russell W. Graymer, Sebastian Roberts, Naomi B. Kalman, and Steven Sobieszczyk

Plate 2 Susceptibility to Shallow Landsliding Modeled for the Oakland-Berkeley Area, Northern California

Kevin M. Schmidt and Steven Sobieszczyk

Plate 3 Susceptibility to Shallow Landsliding Modeled for the Cities of Oakland and

Piedmont Northern California

Kevin M. Schmidt and Steven Sobieszczyk

Plate 4 Seismic Landslide Hazard Modeled for the Cities of Oakland, Piedmont, and

Berkeley, Northern California

Scott B. Miles and David K. Keefer 


\section{Introduction}

\section{By Russell W. Graymer}

With the exception of Los Angeles, perhaps no urban area in the United States is more at risk from landsliding, triggered by either precipitation or earthquake, than the San Francisco Bay region of northern California. By January each year, seasonal winter storms usually bring moisture levels of San Francisco Bay region hillsides to the point of saturation, after which additional heavy rainfall may induce landslides of various types and levels of severity. In addition, movement at any time along one of several active faults in the area may generate an earthquake large enough to trigger landslides. The danger to life and property rises each year as local populations continue to expand and more hillsides are graded for development of residential housing and its supporting infrastructure (Pike and others, 2003).

Landslides are similar to the San Francisco Bay region's more widely recognized natural hazard - earthquakes - in that experts know that landslides will happen, as well as generally where they are most likely to happen, and, in some instances, approximately when to expect them. Predicting more exactly when and where either hazard might occur remains an important area of ongoing research worldwide (van Westen and others, 2006). As advances in landslide science and engineering improve our ability to make experimental forecasts for certain types of landslides, some of the potentially most dangerous localities and site conditions can be evaluated and mapped. This report describes recent progress toward better identifying such localities and conditions.

In the San Francisco Bay region, different types of landslides occur under different sets of geological and meteorological circumstances, or scenarios, and so no one approach is sufficient to map the potential landslide hazard. Multiple assessments derived from different predictive models are essential. For example, in anticipation of the stormy winter resulting from the 1997-98 El Niño climatic anomaly, the U.S. Geological Survey prepared computer models and maps that estimated the geographical distribution of rainfall thresholds and the general locations likely to be debris-flow source areas and large landslides for the entire 10-county Bay region: the resulting six-part folio contained 36 digital maps at scales of 1:125,000 and 1:275,000 (San Francisco Bay Landslide Mapping Team, 1997). The current study follows herein the same many-sided approach to quantifying the spatial extent of the landslide hazard, except that the data and interpretations are reported in greater detail for a smaller area and with an additional scenario for earthquake-triggered failure.

The study area is located centrally in the San Francisco Bay region, directly east of San Francisco Bay in western Alameda and Contra Costa Counties. The study area, which consists of seven U.S. Geological Survey 7.5' quadrangles (fig. I-1), includes all of the cities of Oakland, Berkeley, Orinda, and San Leandro, most of the adjoining cities of
Richmond and Hayward, and all or part of several smaller communities (for example, Piedmont). Following the damaging El Niño winter of 1997-98, the U.S. Geological Survey initiated several studies to provide hazard information to the cities of Oakland and Berkeley in cooperation with the Federal Emergency Management Agency, which designated these two cities among others as part of their Project Impact, a Federal initiative to reduce the potential for loss from natural hazards in communities nationwide.

The study area contains part of the broad, flat East Bay Plain, which extends west to the San Francisco Bay, as well as several steep, northwest-trending ridges and valleys to the east. The active Hayward Fault Zone, which is the fault most likely to generate a large damaging earthquake in the region (Working Group on California Earthquake Probabilities, 1999), crosses the study area at or near the eastern edge of the East Bay Plain. The ridged upland topography results from dextral transpression (right-lateral shear combined with compression) in the fault zone, which creates ongoing uplift of about $1 \mathrm{~mm} / \mathrm{yr}$ in the Oakland hills (Gilmore, 1992; Jones and others, 1994). Underlying the hills are Mesozoic oceanic igneous and sedimentary rocks of the Franciscan Complex and the Great Valley complex near the Hayward Fault Zone, as well as Tertiary and Upper Cretaceous marine and nonmarine strata farther east (fig. I-1; see also, Graymer, 2000).

Unstable slopes are a major hazard in the OaklandBerkeley area, as is shown by many historic disasters (fig. I-2). During the extremely wet winter of 1997-98, landslides resulted in \$47 million in damage in Alameda and Contra Costa Counties alone, much of it in the study area (Graymer and Godt, 1999; Coe and others, 1999). In January 1982, landslides caused by a single very large storm wrought $\$ 13.6$ million in damage in the two counties, again concentrated in the study area (Creasey, 1988). Widespread landsliding also resulted from heavy rainfall in the Oakland area and the surrounding San Francisco Bay region in the winters of 1905-06, 1906-07, 1949-50, 1955-56, 1961-62, 1964-65, 1966-67, 1969-70, 1972-73, 1974-75, 1977-78, and 1979-80 (Brown, 1988). In addition, large earthquakes triggered landslides in the study area in 1836, 1868, 1906 (Youd and Hoose, 1978), and, most recently, 1989 (Keefer, 1998).

Landsliding in the San Francisco Bay region is not a simple phenomenon but, rather, may include a variety of failure mechanisms that can be activated by three different events: a single large storm, an exceptionally wet winter, or an earthquake. Depending on the initiating event, the resulting types of landslides (Varnes, 1978) may include debris flows, earth flows, rock slumps, rock slides, rock falls, earth slides, or topples (Radbruch and Weiler, 1963; Nilsen and Turner, 1975; Nilsen and others, 1976; Ellen and others, 1988; Coe and others, 1999; Graymer and Godt, 1999). The likelihood of landsliding, moreover, varies both by location within the study area and by the type of movement, so that a particular neighborhood might be highly predisposed to rock slumps and rock slides but less likely to host debris flows. Thus, no single answer exists to the question that is 
frequently asked about specific locales, "What is the level of landslide hazard here?"

This report delineates the potential distribution of two basic types of landslides - shallow failures (especially debris flows) and deep-seated failures (mostly landslides other than debris flows) - resulting from the three types of natural events that historically have generated slope movements in the area.
These distributions are shown on four full-color maps (pls. 1 through 4) that depict the relative predisposition of a hillside to fail under a specific set of initiating conditions. Geographical extent of the maps varies: the maps on plates 1 and 2 cover the entire seven-quadrangle study area; the map on plate 3 includes just the city of Oakland and town of Piedmont; and the map on plate 4 includes just the cities of Oakland and Berkeley and

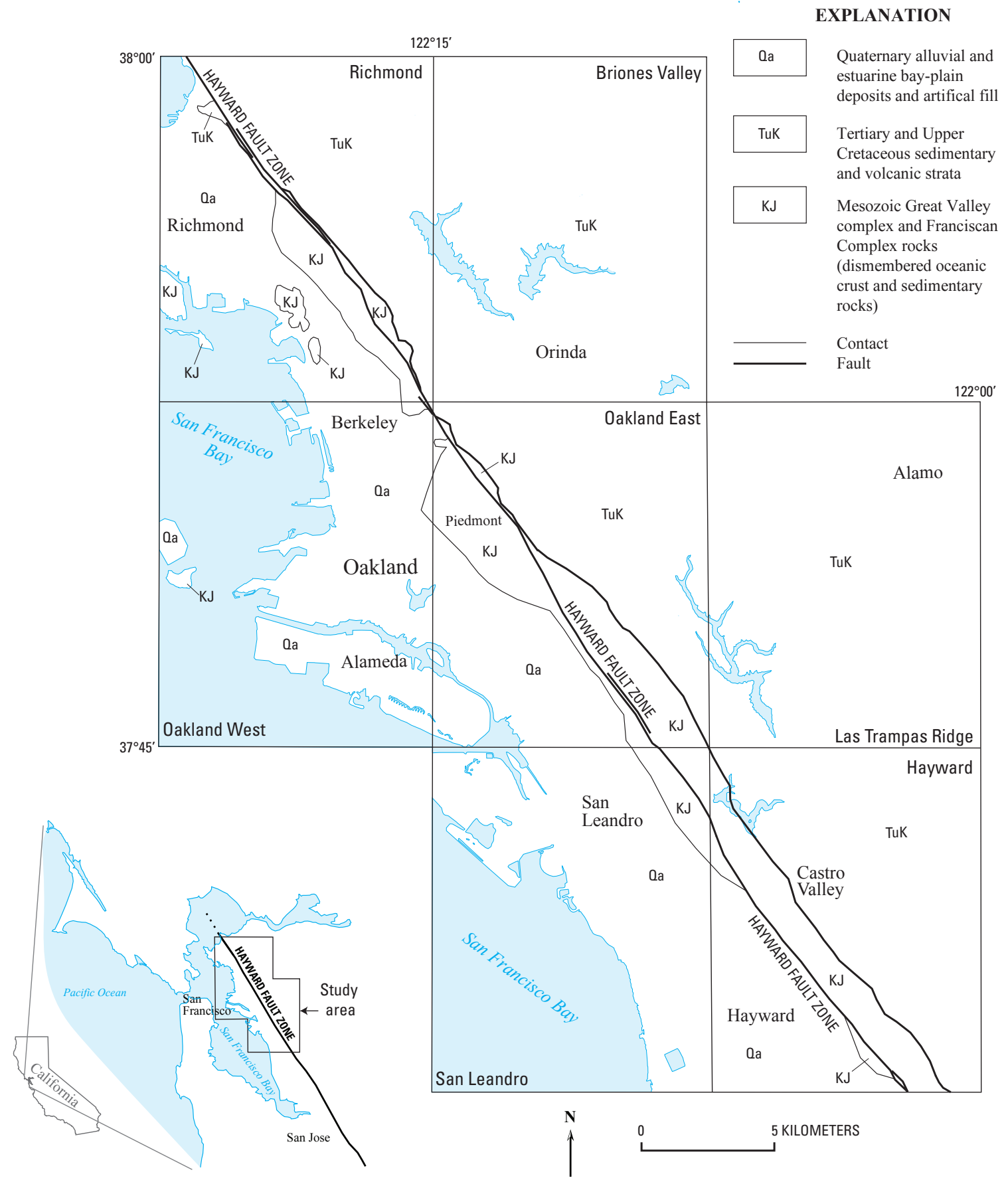

Figure I-1. Index map showing 7.5' quadrangles and various cities and towns in study area, as well as distribution of geologic materials and position of Hayward Fault Zone. Quaternary alluvial deposits, mostly valley fill, east of Hayward Fault Zone are not shown. 
the town of Piedmont. The maps emphasize the close relation between triggering event and distribution of the resulting landslide types; each of the three scenarios yields a different mix of landslide types having a different spatial extent. The maps do not incorporate the likelihood of the triggering events themselves, nor do they attempt to predict the temporal frequency, or return period, of such events - these are ongoing research problems in applied meteorology and seismology that lie beyond the scope of this study.

The report consists of five separate chapters, four of which address specific landslide processes and initiating events that are common to the San Francisco Bay region:

Chapter 1 contrasts two triggering scenarios that result from high levels of precipitation: a single very large storm, and a long wet winter. This chapter discusses why a single large storm will be more likely to generate small, shallow landslides, whereas a prolonged rainy season will tend to induce larger, deeper landslides; the chapter further describes the amount of rainfall that will trigger the contrasting types of failures as well as control their distribution.

Chapter 2 is on susceptibility to larger landslides such as earth flows, rock slides, and rock slumps; it includes one map at 1:50,000 scale (pl. 1). This chapter shows that the larger, deeper landslides are more common on moderately steep $\left(10^{\circ}-30^{\circ}\right)$ slopes and that their distribution correlates closely with the type of underlying rock.

Chapter 3 is on susceptibility to rainfall-triggered shallow landslides (mostly debris flows) in shallow soil and steep
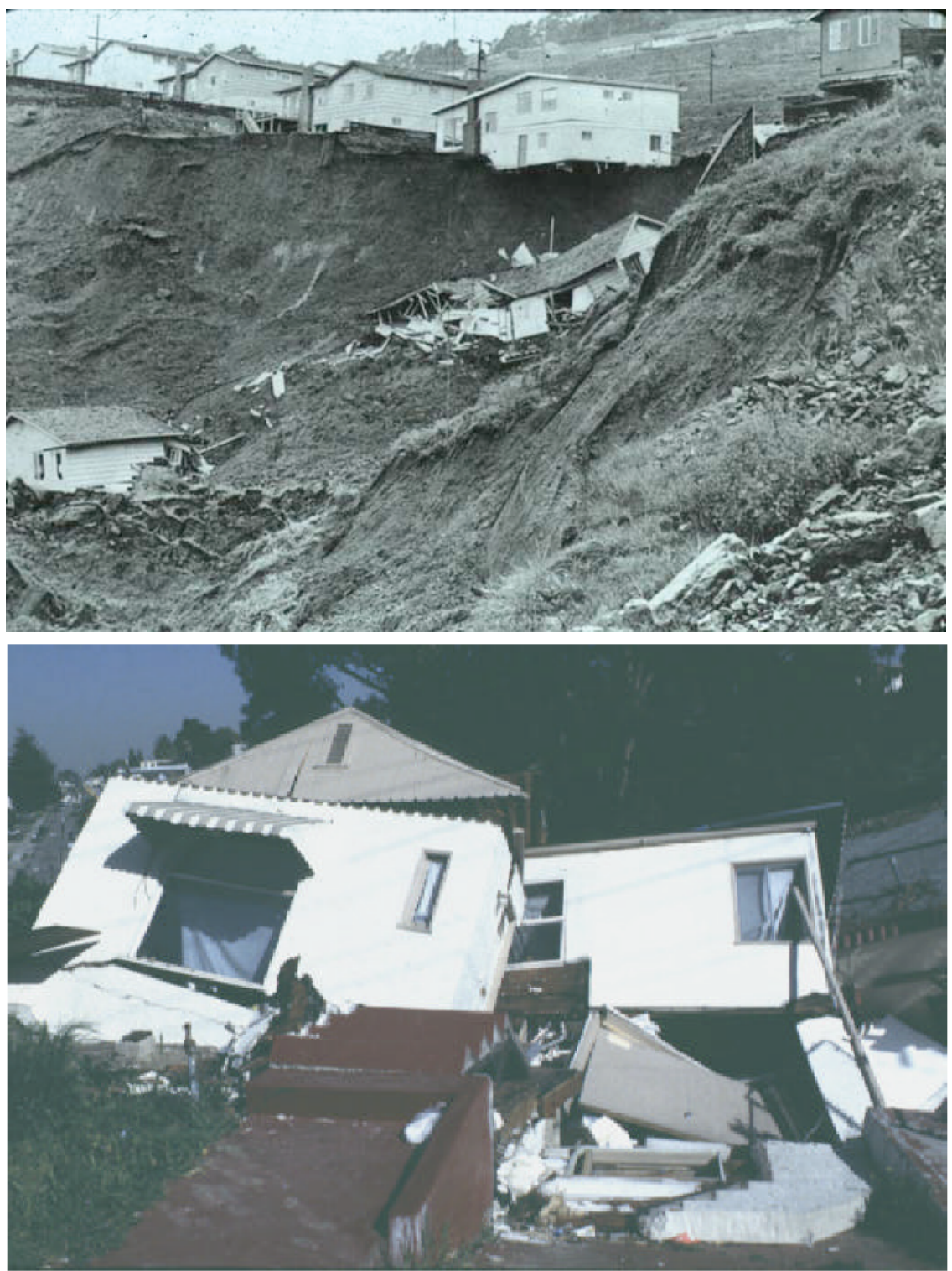

Figure I-2. Homes in Oakland destroyed by landslides: top, March 1958 (Oakland Tribune photograph); bottom, February 1998 (U.S. Geological Survey photograph). 
terrain. This chapter describes how shallow landslides are likely to originate in colluvium (soil and weathered rock) in hollows near the top of a hillslope; the susceptibility is shown on two maps, one at 1:50,000 scale (pl. 2) and one at 1:24,000 scale (pl. 3).

Chapter 4 is on landslides that may be triggered by a major earthquake on the Hayward Fault Zone. The accompanying 1:24,000-scale map (pl. 4) shows the actual hazard, rather than susceptibility only, because the modeled scenario incorporates the triggering event.

Chapter 5 compares the landslide-hazard scenarios presented in the earlier chapters by describing the differences among the four maps on plates 1 through 4 and their relation to local land use; it also notes additional controls on landsliding and summarizes the conclusions of this report.

The intended audience for this report includes the technical, emergency-services, and planning communities. Although much of the discussion in the following chapters is relatively technical, the maps on the accompanying plates are intended to be understood by anyone. The maps and text should be useful for zoning, emergency-response planning, and other regional-scale decisionmaking, including more informed decisions on home-buying areas. We emphasize, however, that the maps are not intended to be the sole basis for site-specific decisions, as none of them contains the detailed information required. Furthermore, these products are not a substitute for official State of California Earthquake-Induced Landslide Zone maps (see, for example, Wilson and others, 2003) for any part of the study area. The data from which our maps were created are the best and most up to date available for the study area at the time of publication (2008); however, as discussed in the chapters to follow, updated or additional observations would further narrow uncertainties in the interpretations. Finally, these maps should not be enlarged beyond the nominal scale of the published maps, or be interpreted as having more detail than actually exists. Because the data are presented in digital form, it is easy to enlarge the scale of the maps, but this would not add any real information or detail (although it may reveal small artifacts related only to digital production).

\section{Acknowledgments}

The research described in the chapters of this report was supported variously by the U.S. Geological Survey's Geologic Mapping, Landslide Hazard, and Earthquake Hazard Programs.

\section{References Cited}

Brown, W.M., III, 1988, Historical setting of the stormperspectives on population, development, and damaging rainstorms in the San Francisco Bay region, in Ellen, S.D., and Wieczorek, G.F., eds., Landslides, floods, and marine effects of the storm of January 3-5, 1982, in the San Francisco Bay region, California: U.S. Geological Survey Professional Paper 1434, p. 7-15 [http://pubs.usgs.gov/ pp/1988/1434/].

Coe, J.A., Godt, J.W., Brien, Dianne, and Houdre, Nicolas, 1999, Map showing locations of damaging landslides in Alameda County, California, resulting from 1997-98 El Niño rainstorms: U.S. Geological Survey Miscellaneous Field Studies Map MF-2325-B, scale 1:125,000 [http:// pubs.usgs.gov/mf/1999/mf-2325-b/].

Creasey, C.L., 1988, Landslide damage - a costly outcome of the storm, in Ellen, S.D., and Wieczorek, G.F., eds., Landslides, floods, and marine effects of the storm of January 3-5, 1982, in the San Francisco Bay region, California: U.S. Geological Survey Professional Paper 1434, p. 195-203 [http://pubs.usgs.gov/pp/1988/1434/].

Ellen, S.D., Wieczorek, G.F., Brown, W.M., and Herd, D.G., 1988, Introduction, in Ellen, S.D., and Wieczorek, G.F., eds.: Landslides, floods, and marine effects of the storm of January 3-5, 1982, in the San Francisco Bay region, California: U.S. Geological Survey Professional Paper 1434, p. 1-5 [http://pubs.usgs.gov/pp/1988/1434/].

Gilmore, T.D., 1992, Historical uplift measured across the eastern San Francisco Bay region, in Borchardt, G., Hirschfeld, S.E., Lienkaemper, J.J., McClellen, P., Williams, P.L., and Wong, I.G., eds., Proceedings of the Second Conference on Earthquake Hazards in the Eastern San Francisco Bay Area: California Division of Mines and Geology Special Publication 113, p. 55-62.

Graymer, R.W., 2000, Geologic map and map database of the Oakland metropolitan area, Alameda, Contra Costa, and San Francisco Counties, California: U.S. Geological Survey Miscellaneous Field Studies Map MF-2342, 29 p., scale 1:50,000 [http://pubs.usgs.gov/mf/2000/2342/].

Graymer, R.W., and Godt, J.W., 1999, Map showing locations of damaging landslides in Contra Costa County, California, resulting from 1997-98 El Niño rainstorms: U.S. Geological Survey Miscellaneous Field Studies Map MF-2325-E, scale 1:125,000 [http://pubs.usgs.gov/ $\mathrm{mf} / 1999 / \mathrm{mf}-2325-\mathrm{e} /]$.

Jones, D.L., Graymer, R.W., Wang, C., McEvilly, T.V., and Lomax, A., 1994, Neogene transpressive evolution of the California Coast Ranges: Tectonics, v. 13, p. 561-574.

Keefer, D.K., ed., 1998, The Loma Prieta, California, earthquake of October 17, 1989—landslides: U.S. Geological Survey Professional Paper 1551-C, 185 p. [http://pubs.usgs.gov/pp/pp1551/pp1551c/].

Nilsen, T.H., and Turner, B.L., 1975, Influence of rainfall and ancient landslide deposits on recent landslides (1950-71) in urban areas of Contra Costa County, California: U.S. Geological Survey Bulletin 1388, 18 p.

Nilsen, T.H., Taylor, F.A., and Brabb, E.E., 1976, Recent landslides in Alameda County, California (1940-71) —an estimate of economic losses and correlations with slope, rainfall, and ancient landslide deposits: U.S. Geological Survey Bulletin 1398, 21 p., scale 1:62,500. 
Pike, R.J., Howell, D.G., and Graymer, R.W., 2003, Landslides and cities - an unwanted partnership, in Heiken, Grant, Fakundiny, Robert, and Sutter, J.F., eds., Earth Science in the City, a Reader: American Geophysical Union Special Publication 56, p. 187-254.

Radbruch, D.H., and Weiler, L.M., 1963, Preliminary report on landslides in a part of the Orinda Formation, Contra Costa County, California: U.S. Geological Survey OpenFile Report 63-112, 35 p., scale 1:24,000.

San Francisco Bay Landslide Mapping Team, 1997, San Francisco Bay region, California, landslide folio: U.S. Geological Survey Open-File Report 97-745 [http://pubs. usgs.gov/of/1997/of97-745/].

van Westen, C.J., van Asch, T.W.J., and Soeters, Robert, 2006, Landslide hazard and risk zonation — why is it still so difficult?: Bulletin of Engineering Geology and the Environment, v. 65, no. 2, p. 167-184.

Varnes, D.J., 1978, Slope movement types and processes, in Schuster, R.L., and Krizek, R.J., eds., Landslides - analysis and control: Washington, D.C., Transportation Research Board, National Research Council, Special Report 176, p. 11-33.

Wilson, R.I., Wiegers, M.O., McCrink, T.P., Haydon, W.D., and McMillan, J.R., 2003, Earthquake-induced landslide zones in the Oakland East 7.5-minute quadrangle, Alameda County, California, in Seismic hazard zone report for the Oakland East 7.5-minute quadrangle, Alameda County: California Geological Survey Seismic Hazard Zone Report 080, p. 25-48, plate 2.1 [http://gmw.consrv.ca.gov/shmp/ html/eval_rpts_no.html].

Working Group on California Earthquake Probabilities, 1999, Earthquake probabilities in the San Francisco Bay region, 2000 to 2030 - a summary of findings: U.S. Geological Survey Open-File Report 99-517, 60 p. [http://geopubs. wr.usgs.gov/open-file/of99-517/].

Youd, T.L., and Hoose, S.N., 1978, Historic ground failures in northern California triggered by earthquakes: U.S. Geological Survey Professional Paper 993, 177 p. 
This page intentionally left blank 


\title{
Chapter 1
}

\section{Rainfall Thresholds for Landslide Activity, San Francisco Bay Region, Northern California}

\author{
By Raymond C. Wilson
}

\begin{abstract}
Intensity and duration of heavy rainfall on a steep hillslope interact with the balance between infiltration and drainage rates to determine whether the slope will remain stable or fail as a landslide. Investigating this interaction helps define the amount of rainfall that can trigger landslide activity sufficient to threaten public safety. On natural hillslopes, this threshold level is influenced not only by the site geology but also by the prevailing rainfall climate. The climatic influence is important in the San Francisco Bay region, where the strong orographic effects on rainfall induced by topography affect both individual storms and long-term precipitation trends.

Rainfall thresholds for severe debris-flow activity that results from single storms are fairly well established in the Oakland-Berkeley study area and elsewhere in the San Francisco Bay region. Longer periods of less intense rainfall can trigger other types of landslides: earth flows in deeper soils and various slides and slumps in weak bedrock. These deeper seated failures tend to move more slowly, posing less danger to life, yet they still are very destructive to buildings, roads, and utilities lifelines. Presently, rainfall thresholds for such landslides are poorly constrained.
\end{abstract}

\section{Introduction}

This chapter explains why and how the amounts of rainfall that trigger landslide activity sufficient to threaten public safety can differ, both across the San Francisco Bay region (fig. 1-1) and locally. While intended primarily for emergency-service managers, this information also provides background for the detailed analyses of the Oakland-Berkeley area, the site chosen to demonstrate spatial modeling of landslide susceptibility (likelihood) within the region (see chs. 2 through 4, this report). After a brief review of the basic geologic and climatic principles involved, the two scenarios that most frequently cause widespread landsliding in the region are presented: (1) a single large storm, likely to trigger debris flows (mudslides) in thin soils on steep slopes (see ch. 3); (2) an unusually wet winter, likely to induce deeper, slower moving earth flows in thicker soils on moderately sloping hillsides, as well as several types of slumps and slides in weak rock formations (see ch. 2). A large earthquake, such as that modeled in chapter 4, may intensify the latter scenario in the Oakland-Berkeley area.

\section{Slope Stability-a Balance of Forces}

Two sets of forces compete to shape the hillsides in steep terrain: the load imposed by gravity, which tends to pull the hillside materials downslope, versus the resistance of these materials to moving. Gravitational loading, acting in the downslope direction, is proportional to the weight of the soil. The resistance of slope materials to sliding or other deformation is expressed by shear strength. For most hillslope materials, shear strength is derived largely from the frictional forces between the grains of soil or rock. Frictional strength also is proportional to the weight of the soil, but it acts in the direction normal (perpendicular) to the slope. These forces - load and resistance - are exactly in balance on a hillside that slopes at the angle of repose, the gradient at which the downslope component of the soil weight is equal to the normal component times the coefficient of friction. The angle of repose differs locally according to underlying materials, slope gradient, vegetation, and soil moisture. A slope whose gradient is less than the angle of repose is stable and will remain at rest under normal circumstances. At gradients above this angle, the slope is oversteepened and may fail catastrophically in a triggering event.

\section{Soil Moisture-Tipping the Balance}

Excess soil moisture can weaken a hillslope's resistance to sliding in three ways. First, moisture may reduce the cohesion that binds soil particles together. Second, if enough moisture collects to saturate (fill up) all pore spaces in the soil or rock, it will generate pore pressures that act against the normal component of the weight of the soil, thereby reducing frictional resistance. Third, moisture increases the weight of the slope materials. The first factor, reduced cohesion, is 
most significant in soils rich in clay. Although the third factor, increased weight of slope materials, is mentioned frequently by the media and in some older textbooks, it actually is of minor significance in most situations. Almost always, the second factor, positive pore-water pressure, is the most important of the three.

Pore-pressure effects are the direct cause of one of the most dangerous types of landslide, the debris flow, which may move very rapidly down steep hillslopes during or immediately after a period of heavy rainfall. The importance of pore pressures in reducing the frictional strength of a hillslope is illustrated by the fact that the angle of repose of a typical hillslope soil under dry conditions is $32^{\circ}$, whereas the angle of repose of the same material under fully saturated conditions is only $16^{\circ}$. Accordingly, many existing hillslopes, both natural and man-made, are stable under dry or unsaturated conditions, but they become dangerously unstable when sufficient soil moisture accumulates to raise pore-water pressures.

How does excess moisture accumulate on California hillslopes? The source is almost always precipitation: rainfall in the California Coast Ranges and snow melt in the higher elevations of the Sierra Nevada. Not all rainfall, however, leads to landsliding. As described below, much of the rainfall early in the winter season simply is absorbed into soil that was dehydrated during the long dry season (usually June through September). Even if the soil is fully rehydrated, rainwater

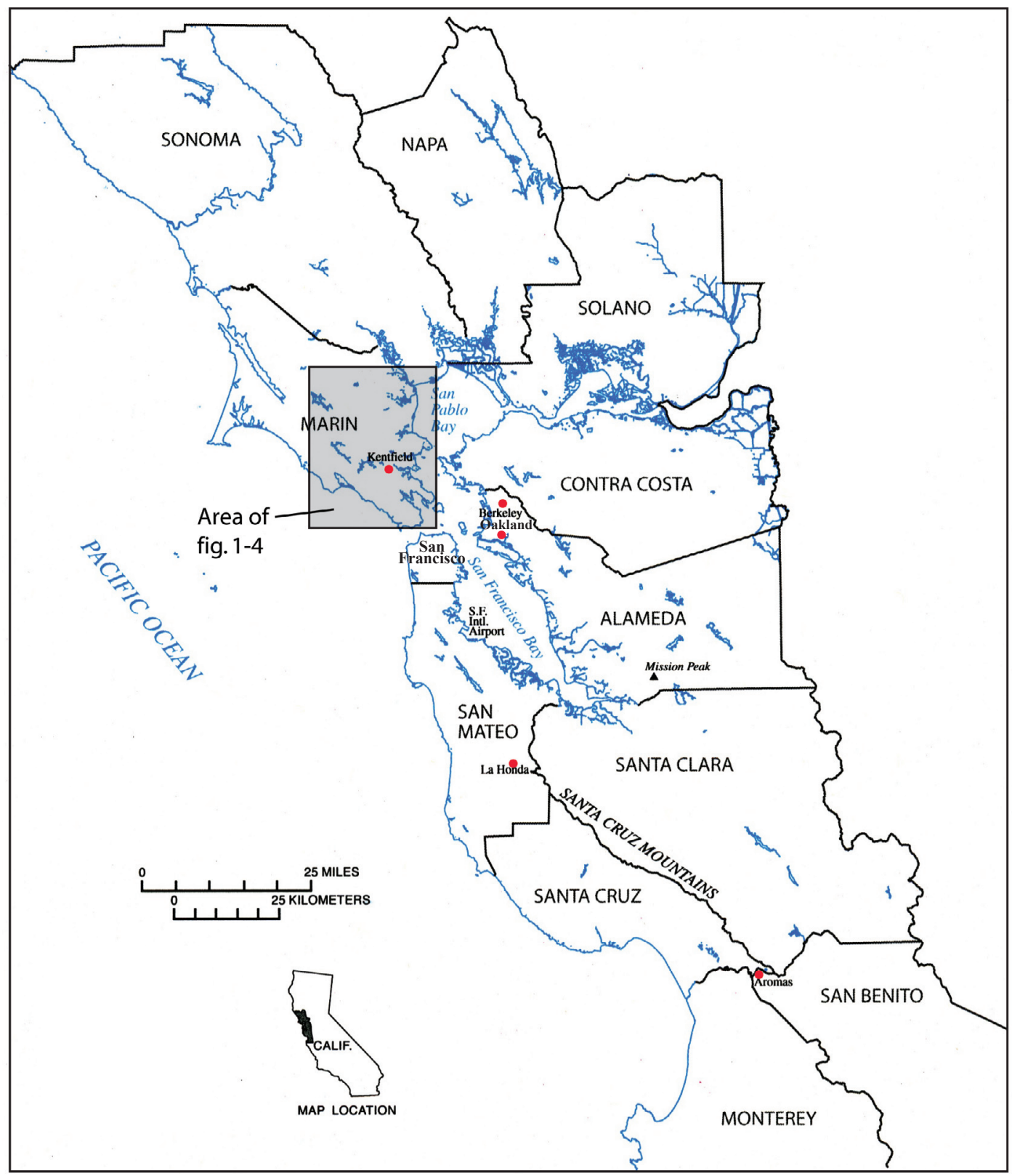

Figure 1-1. Map of San Francisco Bay region, showing locations mentioned in this chapter and area of fig. 1-4. 
may infiltrate into the hillslope, only to quickly drain away down a dense network of shallow surface channels. For enough moisture to accumulate to significantly reduce slope stability, rainfall must reach a critical intensity (magnitude) and be sustained for a critical duration (length of time). The critical levels of intensity and duration are the rainfall thresholds required for landslide activity. Assigning actual values to these thresholds (that is, $X$ inches in $Y$ hours) greatly increases the ability to forecast and prepare for landsliding in the Oakland-Berkeley Hills and elsewhere in the San Francisco Bay region.

\section{The Requirement for a Minimum Amount of Seasonal Rainfall}

Although it is customary to describe the precipitation climate in terms of the mean annual precipitation (MAP), the rainfall in the California Coast Ranges is highly skewed between seasons: the winters are wet and the summers are dry. The result is a lagged seasonal variation in the moisture content of the hillslope soils. By the start of the winter rainfall season, the hillslope soils have been dehydrated by evapotranspiration (evaporation and transpiration) during the long, dry summer and fall. The remaining soil moisture is held in place under strong soil suctions (tensile forces). Until the moisture deficit is restored by early seasonal rainfall, the conductivity (movement) of moisture will be slow, and high soil suctions will prevent the formation of the positive pore-water pressures necessary for slope failure. Thus, debris flows are unlikely to occur early in the rainfall season (Campbell, 1975).

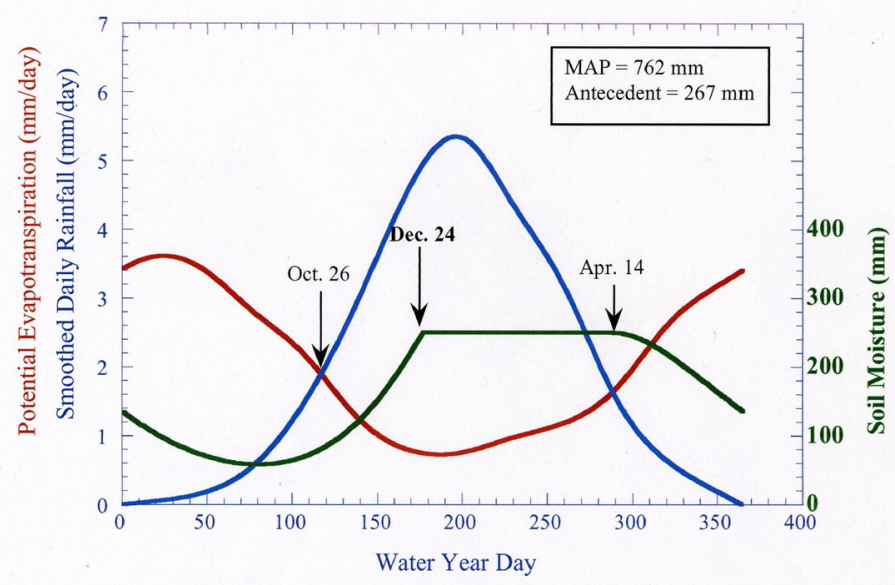

Figure 1-2. Graph showing annual cycle of rainfall (blue curve), evapotranspiration (red curve), and resulting soil moisture (green curve) typical of the Santa Cruz Mountains near La Honda, California (see figure 1-1 for location). Overall shapes of curves also apply to Oakland-Berkeley Hills and other upland terrain in San Francisco Bay region. Water year begins July 1.
The amount of early seasonal rainfall required to rehydrate the hillslope soils is a complex balance of (1) the initial moisture content, (2) the losses to evapotranspiration, and (3) the thickness of material that has been dehydrated. The resumption of rainfall in late autumn, however, coincides with lower temperatures and shortened daylight, when evapotranspiration is reduced, and so rehydration of the hillslope materials proceeds rapidly (fig. 1-2). In a typical rainfall season, this antecedent (restored) soil-moisture condition generally is reached in most areas within a few weeks after the winter solstice (Wilson, 1997). The threshold rainfall amounts discussed below are predicated on the assumption that the minimum antecedent soil-moisture requirement already has been satisfied by early seasonal rainfall.

\section{Orographic Effects on Rainfall Distri- bution}

Across the San Francisco Bay region, winter storms from the North Pacific Ocean interact with the local topography in complex patterns, producing significant variations in both the MAP and the frequency of storms of a given size (Rantz, 1971). As a North Pacific winter storm front makes landfall, it typically encounters higher elevations, and its moist air is forced to follow the local ground surface upward, as much as hundreds or thousands of meters vertically within a few tens of kilometers of lateral movement. This abrupt orographic lifting (rise in elevation) subjects the air mass to adiabatic cooling, thereby increasing condensation and precipitation, so that, on a long-term average, higher precipitation occurs at higher elevation on the windward sides of topographic highs. For example, a storm that produces 3 inches $(76 \mathrm{~mm})$ of rain at such sea-level locations as the San Francisco International Airport (fig.1-1) might deliver 7 inches $(178 \mathrm{~mm})$ at the higher elevation of Kentfield (fig.1-1), a few kilometers north in Marin County, or more than 10 inches $(254 \mathrm{~mm})$ along the crest of the Santa Cruz Mountains.

On the leeward side of a mountain range, however, storm rainfall is quickly depleted by the rain shadow effect. As storm systems pass over the ridge crest and descend the leeward flank of the range, the loss in elevation causes them to undergo adiabatic warming, which markedly decreases condensation and precipitation. The long-term result is a significantly lower MAP on the leeward flank of the range. For this reason, the inland portions of eastern Alameda and Contra Costa Counties have approximately half the MAP of the coastal areas of Marin and San Mateo Counties. Finer scale topographic effects on local amounts of rainfall are described in chapter 5 (this report).

\section{Landslides and Rainfall-Scaling in Space and Time}

Rainfall tends to trigger different-sized landslides over different periods of time. Debris flows, which tend to be 
small, may occur on steep $\left(>20^{\circ}\right)$ hillslopes in thin, sandy soils from a single intense burst of rainfall lasting just a few hours. On somewhat gentler $\left(12^{\circ}-20^{\circ}\right)$ slopes underlain by thicker (several meters) soils that are richer in clay, earth flows may be induced by one or several storms of more moderate intensity extending over several days to a few weeks. Larger, deeper $(>5 \mathrm{~m})$ landslides may occur in weak bedrock (for example, shales, serpentinite, or poorly cemented sandstones) after a winter season that has an unusually high total rainfall amount. Multiyear sequences of above-normal precipitation, associated with the El Niño/Southern Oscillation (ENSO) phenomena in the Pacific Ocean, also may mobilize large, deep landslides across the region, as happened in the early 1980's and the late 1990's.

The critical factor that locates a particular hillslope on this size/time spectrum of slope failure is the depth of the potential slide surface (the local subsurface plane of weakness that has the lowest stability). A deeper slide surface underlies a comparatively larger volume of material that the rainwater must saturate to bring about the failure. On the other hand, the rate at which water drains away from the hillslope diminishes sharply with increasing depth: a deeper slide surface requires a longer time for the higher volume of material to accumulate moisture before a landslide occurs. The result is a tradeoff between the amount of rainfall that must be accumulated and the period of time over which this rainfall may be gathered.

Figure 1-3 illustrates the spectrum of landslide sizes with respect to the critical rainfall amounts and durations required to destabilize a typical hillside in the San Francisco Bay region. Debris flows, for example, characteristically

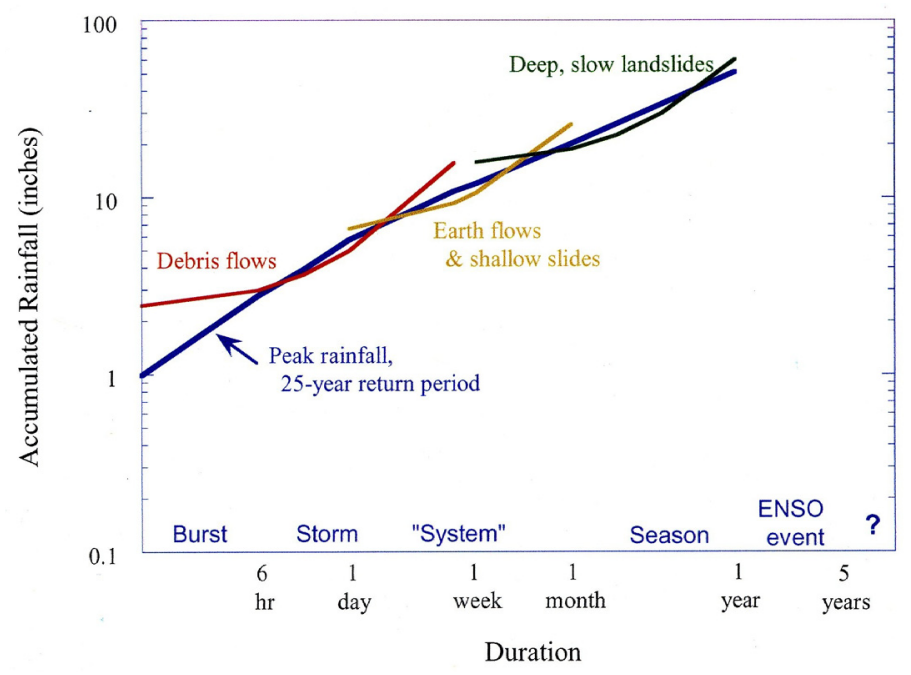

Figure 1-3. Graph of temporal spectra of rainfall phenomena and landslide types, showing rainfall amount/duration thresholds for spectrum of landslide sizes and types for typical hillside in San Francisco Bay region. Rainfall phenomena range in duration from burst (brief storm) to an El Niño/Southern Oscillation (ENSO) event. Landslide types range in size from small debris flows to large, deep, slow landslides. are triggered by single storms that accumulate 3 to 15 inches of rainfall in a few hours to a couple of days. Earth flows and shallow rock slides are more likely to be induced by accumulations of 6 to 26 inches over a few days to a month. Deep, slow landslides require much higher total accumulations (16-60 in) over much longer periods of time (weeks to months). According to the depth-duration-frequency spectrum of rainfall in the San Francisco Bay region (Rantz, 1971), these different combinations of rainfall amount and duration all have roughly equal probabilities of occurrence (2-5\% per year).

\section{Two Failure Scenarios}

The following discussion considers two sets of circumstances under which rainfall of unusual intensity and (or) duration may cause landsliding in the Oakland-Berkeley study area (see chs. 2 through 4, this report) and elsewhere in the San Francisco Bay region:

1) Single Large Storm: Debris flows (see ch. 3) and other shallow landslides may be triggered by intense rainfall $(>0.25 \mathrm{in} / \mathrm{hr})$ that is sustained over several hours. Empirical rainfall/debris-flow thresholds are fairly reliable and may be combined with rainfall size-frequency distributions to estimate risk probabilities and plan emergency-response strategies.

2) Unusually Wet Winter: Larger, deeper landslides (see ch. 2) may be generated by excess moisture accumulated over a period of rainfall of lower intensity but of longer overall duration (weeks to months). Such a scenario might prevail, for instance, during a long sequence of closely spaced storm fronts during an El Niño period, as occurred in northern California during the 1982-83 and 1997-98 rainfall seasons. At present, rainfall thresholds for these large, deep seasonal landslides are not well constrained.

\section{Scenario 1: Landslides from a Single Large Storm}

To trigger debris flows in the San Francisco Bay region, a storm must attain a critical combination of rainfall intensity and duration (Cannon and Ellen, 1985; Cannon, 1988). Most individual rainstorms in the region last a few hours to, at most, a few days, but they can be accompanied by periods of intense rainfall. The archetypal example of this scenario is the catastrophic storm of 3-5 January 1982, which generated 18,000 debris flows across the region, causing 25 deaths and \$66 million in property damage (Ellen and Wieczorek, 1988).

In previous work in southern California, Campbell (1975) found that a sustained period (at least several hours) of rainfall at a rate exceeding $0.25 \mathrm{in} / \mathrm{hr}$ is required to trigger hazardous debris-flow activity. Campbell hypothesized that this threshold combination of rainfall intensity and duration reflected the balance between the rate of rainfall infiltration into the 
hillslope materials and the rate at which water drains back out of the hillslope. The steep, sandy hillslopes where debris flows are most likely to occur generally drain rapidly, so that drainage usually keeps pace with low or moderate rainfall rates. Intense rainfall, however, can overwhelm this established drainage rate, leading to saturation of the hillslope soils, generation of positive pore-water pressures within the soil, and, ultimately, slope failure (Campbell, 1975).

\section{Development of Rainfall Thresholds}

In the wake of the January 1982 storm, Cannon (1988) devised a regional set of threshold rainfall values for debrisflow initiation by comparing data on rainfall intensity and duration from this storm to similar data from other large historical storms that did not trigger significant debris-flow activity. Cannon selected observations from rain gauges that were closest to areas of intense debris-flow activity; the rainfallintensity data were then normalized by dividing them by the long-term MAP for the rain gauges. Cannon plotted the normalized data against the corresponding time interval and drew a line separating the January 1982 storm data from data for storms that failed to induce debris flows (Cannon, 1988, p. 41, fig. 4.3). This line of separation was proposed to approximate the regional rainfall threshold for debris-flow initiation.

Together with a network of radio-telemetered automatic rain gauges, called the Automatic Local Evaluation in Real Time (ALERT) network, the regional rainfall threshold of Cannon (1988) served as the basis for a Landslide Warning System in the San Francisco Bay region, maintained jointly by the U.S. Geological Survey (USGS) Landslide Research Group and the National Weather Service (NWS) from 1986 to 1995 (Keefer and others, 1987). During its period of operation, several storms triggered debris flows locally (Wilson and others, 1993), and rainfall data from gauges near areas of debris-flow activity generally exceeded, or at least approached, the threshold values of Cannon (1988).

Data from ALERT gauges in low-rainfall areas, however, appeared to yield "false alarms" with inordinate frequency (R. Mark, unpub. data, 1995), bearing out Cannon's (1988, p. 38) caution that "normalization introduces inconsistencies in areas of low MAP." Furthermore, studies of rainfall thresholds in other regions along the Pacific Coast of the United States (Wilson, 1997) suggested that applying MAPnormalized thresholds from the San Francisco Bay region to either southern California or the Pacific Northwest yielded significantly underestimated or overestimated thresholds, respectively.

\section{Climatic Normalization}

Cannon (1988) normalized thresholds by the MAP to correct for rainfall variations in individual storms caused by local orographic effects, certainly a positive step. Also, the MAP is the parameter most commonly used to describe the long-term precipitation climate and is, by far, the measure most easily obtained from published sources. The MAP, however, is not always a good predictor of the amount of rainfall that constitutes an "extreme event." The MAP actually reflects a combination of two processes: (1) the distribution of sizes of individual rainstorms, and (2) the total number of rainstorms during the year. Thus, in estimating rainfall/debris-flow thresholds, storm-size distribution appears to be more important than the total number of storms.

Rain gauges in the Pacific Northwest, for example, may show a high MAP because of a high frequency of relatively small storms. Astoria, at the mouth of the Columbia River in northwest Oregon, has a MAP value of 67.69 inches and enjoys an average of 225 days of rainfall per year. Many locations in southern California, by contrast, have a much lower rainfall frequency but a higher proportion of large rainfall events. Big Tujunga, a canyon in the San Gabriel Mountains above Los Angeles, has an average rainfall frequency of only 43 days per year and a MAP value of 25.51 inches, less than a third of the MAP in Astoria. Yet a daily rainfall amount that exceeds 4 inches, a very rare event in Astoria (only twice in a 47-year record), is a fairly frequent event at Big Tujunga (39 times in a 50 -year record). Even a daily rainfall total that exceeds 2 inches is more common at Big Tujunga (169 times in 50 years) than in Astoria (106 times in 47 years), despite the much higher MAP in Astoria. What constitutes an "extreme event" in Astoria, therefore, would be fairly ordinary at Big Tujunga. Conversely, an "extreme event" at Big Tujunga might be virtually impossible at Astoria.

As the above example shows, an improved understanding of the interaction between a hillslope and the precipitation that triggers debris flows requires moving beyond the MAP to a more fundamental examination of the long-term precipitation climate. As a working assumption, consider that the landscape equilibrates over a period of time (decades to centuries) to the prevailing climate such that under normal conditions, the hillslope can balance infiltration against evapotranspiration and surface runoff while maintaining gravitational stability. The severe rainstorms that induce significant debris-flow activity, on the other hand, are "extraordinary events, when rainfall at a particular site exceeds the commonly occurring conditions" (Cannon and Ellen, 1988, p. 30).

The process of long-term equilibration entails a number of mechanisms, both known and unknown. Adjustments in the variety and abundance of hillslope vegetation may raise or lower the evapotranspiration rates and cause a decrease or increase (respectively) in the soil moisture. Adjustments in vegetation might also raise or lower the strength and abundance of root fibers within hillslope soils, causing changes in the (apparent) cohesion factor of the soil shear strength (see ch. 3, this report). Because hillslope soils commonly are thin (less than a few meters) and occupy slopes near the angle of repose of the material, even a small change in soil cohesion can greatly affect hillside stability. Equilibration of hillslope vegetation to long- 
term precipitation could occur over as short a time period as several decades to a few centuries.

Whatever the exact equilibration processes, a scheme that normalizes rainfall/debris-flow thresholds should clearly identify storms that are "extreme events," as contrasted with the more frequent, but much smaller, storms that dominate the MAP value for most stations. In particular, the statistical problems arising from significant variations in rainfall frequency should be avoided. It would also be helpful if the normalization scheme did not require that the rainfall sizefrequency distribution take a particular form.

One approach is to replace the MAP with an estimate of the rainfall from a "reference storm." Such an estimate is based on a fixed return period that is long enough to filter out the small, frequent rainfall events that dominate the MAP values, yet short enough that an empirical estimate of the "reference storm rainfall" can be extracted from a few decades of daily records. After experimentation with various return periods, a value of five years was found to be an optimal value for the return period of the reference storm (Wilson, 2000).

\section{Levels of Debris-Flow Activity}

The rainfall/debris-flow thresholds developed from the January 1982 storm were intended to correspond to a fairly high level of debris-flow activity. More than 18,000 debris flows were mapped throughout the 10-county San Francisco Bay region after the storm, and some small local areas had spatial densities that reached as high as 25 events per square kilometer (Ellen and Wieczorek, 1988). After the Landslide Warning System began operation in 1986, however, it quickly became apparent that the system needed to include a broader range of debris-flow activity. For example, significant debris-flow activity may occur at lower levels of rainfall intensity and duration, particularly along roadways or drainage channels where cuts and embankments are more susceptible to failure than undisturbed slopes. Such roadside debris flows pose a hazard to life and property by creating an unexpected obstruction. Other debris flows that block natural streams or artificial drainage channels can impound or divert heavy storm runoff, thereby causing further damage from erosion and inundation.

These considerations led to the development of a dual-track set of rainfall intensity/duration thresholds, which together outline a spectrum of debris-flow activity. The lower, "safety" level was adapted from the threshold of Wieczorek (1987) for the initiation of individual debris flows in a 12-square-kilometer site near the rural Santa Cruz Mountains town of La Honda (about $60 \mathrm{~km}$ south of the Oakland-Berkeley study area; see fig. 1-1)). This lower threshold represents a rainfall level below which significant debris-flow hazards are considered unlikely. The upper, "danger" level was adapted from the threshold of Cannon and Ellen (1985), which is based on a comparison of the January 1982 storm with previous storms in the San Francisco Bay region. This higher threshold represents a rainfall level above which abundant debris flows are likely to occur across a broad area.

Storms that had peak rainfall periods below the lower "safety" threshold were considered unlikely to trigger hazardous debris flows and so generally required no public statements. For storms that had rainfall levels just above the lower threshold, a brief statement was broadcast by the NWS, warning motorists that roadways may be obstructed by rock falls or debris flows. If rainfall was forecast to approach the upper "danger" threshold, a stronger statement was issued, advising people living on or below steep hillsides, or near creeks, to stay alert and be prepared to evacuate, as debris flows were considered a strong possibility during the watch period. When rainfall was observed to exceed the upper threshold, or if reports of significant debrisflow activity were received, the strongest statement-a NWS Flash Flood/Debris Flow Warning - was issued.

This system of dual rainfall/debris-flow thresholds provides a degree of flexibility in dealing with uncertainties in weather forecasting, as well as with the even broader uncertainties in predicting how many debris flows would be triggered if the thresholds were exceeded (Wilson and others, 1993).

\section{Emergency-Response Planning}

In preparation for the widely anticipated 1997-98 El Niño season, the rainfall-threshold values of Wilson and others

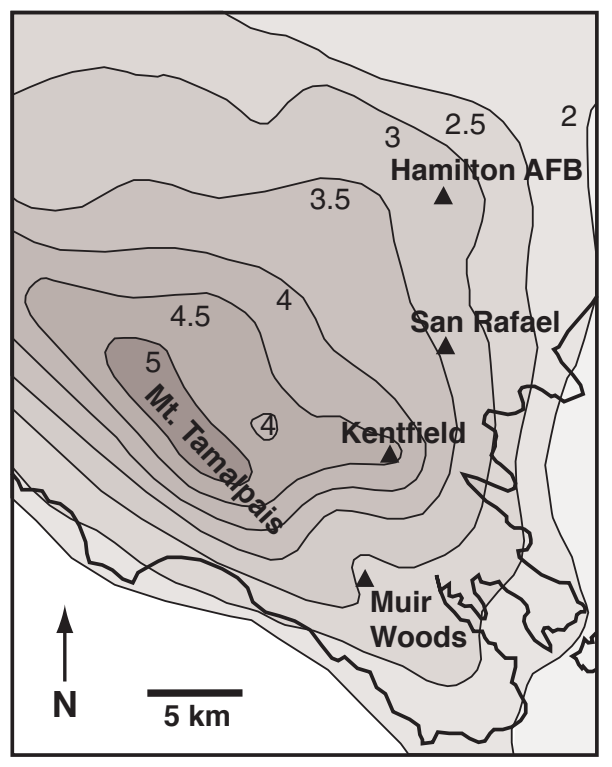

Figure 1-4. Map showing rainfall thresholds for debris-flow activity in southern Marin County. Different amounts of rain (here, 2 to 5 in) in same period ( 6 hours) are needed to upset slope-stability equilibrium at different localities. Rainfall contours at 0.5 inch $(12.5 \mathrm{~mm})$ intervals. Triangles are locations of Automatic Local Evaluation in Real Time (or ALERT) network rain gauges. From Wilson and Jayko (1997). 
(1993) were updated and published in map form by Wilson and Jayko (1997). This map (see sample in fig. 1-4) is intended to be used, together with maps of debris-flow susceptibility such as that of Ellen and others (1997) for the San Francisco Bay region or that of Schmidt and Sobieszczyk (ch. 3, this report) for the Oakland area, to facilitate response planning for debrisflow-related emergencies. The combination of maps should provide both a spatial portrayal of the debris-flow hazard and quantitative thresholds to compare with storm rainfall, either forecast or observed. The threshold map of Wilson and Jayko (1997) and the digital data layers from the susceptibility maps in Ellen and others (1997) or chapter 3 of this report also may be combined with more detailed databases showing residential areas, roadways, utilities, critical facilities, or other infrastructure of interest (Perkins and Chuaqui, 1996), which would allow a more detailed level of planning within various jurisdictions.

\section{Scenario 2: Landslides from an Unusually Wet Winter}

Damaging landslides other than debris flows also are common in the San Francisco Bay region (see, for example, Wentworth and others, 1997), but they are more difficult to predict because their critical rainfall thresholds and antecedent soil-moisture conditions are less well understood. Such deepseated landslides (see ch. 2, this report) tend to be deeper, larger, and slower moving than the debris flows discussed in the single-storm scenario (see ch. 2, this report), and they occur during periods of unusually high rainfall that extend over weeks to months (fig. 1-3). Deep-seated landslides also can be triggered by large earthquakes (see ch. 4, this report).

The very wet $1997-98$ El Niño winter season provided three dramatic examples of non-debris-flow landslides in the San Francisco Bay region: (1) a deep-seated rock slide near La Honda (San Mateo County), which ultimately destroyed eight homes (Jayko and others, 1998); (2) the giant Mission Peak landslide complex in southern Alameda County (fig. 1-1), which failed in late March 1998, near the end of the winter season (Rogers, 1998); and (3) a smaller earth flow near the town of Aromas, just south of Santa Clara County (fig. 1-1), in late April that cut the pipelines supplying natural gas to 60,000 Santa Cruz County residents (Pike and others, 1998). All three landslides were reactivations of older failures. The previous severe El Niño winter (1982-83) also triggered a number of deep-seated slumps and slides, particularly in the North Bay (Marin and Sonoma Counties). Although the El Niño cycle clearly is important, not all exceptionally wet years are El Niño years (for example, 1955-56, 1981-82, and 1996-97).

The pattern typically followed in the development of a larger, slower moving landslide is the initial appearance of minor ground-surface cracks or flexures in midwinter (February), then movement continues through the spring (into March, April, or even May), eventually attaining displacements of as much as several meters or more. Movement generally slows or stops during the dry summer and fall but may reactivate during the next wet winter season. In the Santa Cruz Mountains, recent movements are recurring on slumps that appear to have been moving intermittently for thousands of years (Wells and others, 2005, 2006). This problem is exacerbated in hilly parts of the densely settled Oakland-Berkeley area, where continuing episodic movement is displacing urban house lots from their initially surveyed locations (Hilley and others, 2004).

Critical amounts of rainfall may exist for these larger, deeper landslides, but such thresholds have yet to be determined with any reliability because the less direct but more complex interactions needed to derive them are not yet well understood. Some attempts have been made to model individual non-debris-flow landslides; however, the instrumentation and monitoring (see, for example, Reid and LaHusen, 1998) required to gather the necessary data for many such landslides is impractical, and so no systematic efforts to determine rainfall thresholds regionally are underway currently. Perhaps all that can be said at this time is that, similar to debris flows, an "extreme event" criterion may exist; exceptionally wet years do seem to correlate with non-debris-flow landsliding. The total rainfall amounts from the 1998 Water Year (7/1/1997 to 6/30/1998) at most rain gauges in the San Francisco Bay region were the highest since 1862 , when the rainfall amount in downtown San Francisco was slightly higher. The 1983 Water Year totals also were among the highest on record. Furthermore, the 1998 season followed several other unusually wet seasons, and so some multiyear accumulations of water may have occurred at comparatively great depths $(>10 \mathrm{~m})$ beneath local hillsides.

For purposes of emergency-response planning for these larger, deeper failures, the most practical approach may be to compile, for a given jurisdiction, a map of landslides that have damaged homes, roadways, or other facilities over the past several decades (see ch. 2, this report). The dates of occurrence reported for those slides may be compared to the annual (water year) rainfall for nearby rain gauges to see if any obvious patterns of correlation emerge. Furthermore, the map of damaging landslides may be used as a base map for compiling future reports of displacement or damage so that reactivated landslide movements may be detected at an early stage; this would allow some mitigative action, such as drainage, buttressing, or, as a last resort, the orderly evacuation of threatened dwellings and the removal of household goods. Susceptibility maps, which combine locations of prior landsliding with geology and slope gradient, indicate the relative likelihood of hillside materials to fail (see chs. 2 and 4, this report), and they provide an indication of the areas where nondebris-flow activity might be most expected given sufficient triggering moisture levels or seismic shaking.

\section{Acknowledgments}

R.W. Graymer (USGS) contributed figure 1-1. 


\section{References Cited}

Campbell, R.H., 1975, Soil slips, debris flows, and rainstorms in the Santa Monica Mountains and vicinity, Southern California: U.S. Geological Survey Professional Paper 851, $51 \mathrm{p}$.

Cannon, S.H., 1988, Regional rainfall-threshold conditions for abundant debris-flow activity, in Ellen, S.D., and Wieczorek, G.F., eds., Landslides, floods, and marine effects of the storm of January 3-5, 1982, in the San Francisco Bay region, California: U.S. Geological Survey Professional Paper 1434, p. 35-42 [http://pubs.usgs.gov/pp/1988/1434/].

Cannon, S.H., and Ellen, S.D., 1985, Rainfall conditions for abundant debris avalanches, San Francisco Bay region, California: California Geology, v. 38, no. 12, p. 267-272.

Cannon, S.H., and Ellen, S.D., 1988, Rainfall that resulted in abundant debris-flow activity during the storm, in Ellen, S.D., and Wieczorek, G.F., eds., Landslides, floods, and marine effects of the storm of January 3-5, 1982, in the San Francisco Bay region, California: U.S. Geological Survey Professional Paper 1434, p. 27-34 [http://pubs.usgs.gov/ $\mathrm{pp} / 1988 / 1434 /]$.

Ellen, S.D., and Wieczorek, G.F., eds., 1988, Landslides, floods, and marine effects of the storm of January 3-5, 1982, in the San Francisco Bay region, California: U.S. Geological Survey Professional Paper 1434, 310 p. [http://pubs.usgs.gov/ pp/1988/1434/].

Ellen, S.D., Mark, R.K., Wieczorek, G.F., Wentworth, C.M., Ramsey, D.W., and May, T.E., 1997, Map showing principal debris-flow source areas in the San Francisco Bay region, California: U.S. Geological Survey Open-File Report 97-745-E [http://pubs.usgs.gov/of/1997/of97-745/].

Hilley, G.E., Bürgmann, Roland, Ferretti, Alessandro, Novali, Fabrizio, and Rocca, Fabio, 2004, Dynamics of slow-moving landslides from permanent scatterer analysis: Science, v. 304, no. 5679 , p. 1,952-1,955.

Jayko, A.S., Rymer, M.J., Prentice, C.S., Wilson, R.C., and Wells, R.E., 1998, Scenic Drive landslide of January-March 1998, La Honda, San Mateo County, California: U.S. Geological Survey Open-File Report 98-229 [http://pubs. usgs.gov/of/1998/of98-229/].

Keefer, D.K., Wilson, R.C., Mark, R.K., Brabb, E.E., Brown, W.M., Ellen, S.D., Harp, E.L., Wieczorek, G.F., Alger, C.S., and Zatkin, R.S., 1987, Real-time landslide warning during heavy rainfall: Science, v. 238, p. 921-925.

Perkins, J.B., and Chuaqui, Ben, 1996, Existing land use in 1995 - data for Bay Area counties and cities: Oakland, California, Association of Bay Area Governments, 200 p.

Pike, R.J., Cannon, S.H., Ellen, S.D., Graham, S.E., Graymer, R.W., Hampton, M.A., Hillhouse, J.W., Howell, D.G., Jayko, A.S., LaHusen, R.L., Lajoie, K.R., Ramsey, D.W., Reid, M.E., Richmond, B.M., Savage, W.Z., Wentworth, C.M., and Wilson, R.C., 1998, Slope failure and shoreline retreat during northern California's latest El Niño: GSA Today, v. 8, no. 8, p. 1-6.

Rantz, S.E., 1971, Mean annual precipitation and precipitation depth-duration-frequency data for the San Francisco Bay region, California: U.S. Geological Survey, San Francisco Bay Region Environment and Resources Planning Study Basic Data Contribution 25, 23 p., scale 1:500,000.

Reid, M.E., and LaHusen, R.G., 1998, Real-time monitoring of active landslides along Highway 50, El Dorado County: California Geology, v. 51, no. 3, p. 17-20.

Rogers, D.J., 1998, Mission Peak landslide, Fremont, California [abs.]: EOS, Transactions of the American Geophysical Union, v. 79, p. 266 [http://start.org/cgi-bin/sessions?meeting $=$ fm98\&part $=$ H72F\&maxhits $=200]$.

Wells, R.E., Rymer, M.J., Prentice, C.S., and Wheeler, K.L., 2005, Map showing features and displacements of the Scenic Drive landslide, La Honda, California, during the period March 31-May 7, 2005: U.S. Geological Survey Open-File Report 2005-1191 [http://pubs.usgs.gov/of/2005/1191/].

Wells, R.E., Rymer, M.J., Prentice, C.S., and Wheeler, K.L., 2006, Map showing features and displacements of the Scenic Drive Landslide, La Honda, California, during the period March 31, 2005-November 5, 2006: U.S. Geological Survey Open-File Report 2006-1397, 2 sheets [http://pubs.usgs.gov/ of/2006/1397/].

Wentworth, C.M., Graham, S.E., Pike, R.J., Beukelman, G.S., Ramsey, D.W., and Barron, A.D., 1997, Summary distribution of slides and earth flows in the San Francisco Bay region, California: U.S. Geological Survey Open-File Report 97-745-C, 10 p., 11 sheets [http://pubs.usgs.gov/of/1997/ of 97-745/].

Wieczorek, G.F., 1987, Effect of rainfall intensity and duration on debris flows in central Santa Cruz Mountains, California, in Costa, J.E., and Wieczorek, G.F., eds., Debris flows/avalanches - processes, recognition, and mitigation: Geological Society of America Reviews in Engineering Geology, v. 7, p. 23-104.

Wilson, R.C., 1997, Normalizing rainfall/debris-flow thresholds along the U.S. Pacific coast for long-term variations in precipitation climate, in Chen, C-L., ed., Debris-flow hazards mitigation - mechanics, prediction, and assessment: American Society of Civil Engineers, Hydraulics Division, First International Conference [Proceedings], August 7-9, 1997, San Francisco, California, p. 32-43.

Wilson, R.C., 2000, Climatic variations in rainfall thresholds for debris-flow activity, in Claps, P., and Siccardi, F., eds., Mediterranean storms: European Geophysical Union, First Plinius Conference [Proceedings], 14-16 October, 1999, Maratea, Italy, p. 415-424.

Wilson, R.C., Mark, R.K., and Barbato, G.E., 1993, Operation of a real-time warning system for debris flows in the San Francisco Bay area, California, in Shen, H.W., Su, S.T., and Wen, F., eds., Hydraulic engineering '93: American Society of Civil Engineers, Hydraulics Division, 1993 Conference [Proceedings], July 25-30, 1993, San Francisco, California, v. 2, p. 1,908-1,913.

Wilson, R.C., and Jayko, A.S., 1997, Preliminary maps showing rainfall thresholds for debris-flow activity, San Francisco Bay region, California: U.S. Geological Survey Open-File Report 97-745-F, 14 p., 2 sheets, scale 1:250,000 [http://pubs.usgs. gov/of/1997/of 97-745/]. 
Chapter 2

\title{
Susceptibility to Deep-Seated Landsliding Modeled for the Oakland-Berkeley Area, Northern California
}

\author{
By Richard J. Pike and Steven Sobieszczyk
}

\section{Abstract}

In the San Francisco Bay region, either prolonged rainfall or a major earthquake can trigger large, deep-seated landslides, which differ from debris flows and other small, shallow failures. The varying likelihood that hillsides in the Oakland-Berkeley area might incur large landslides is mapped by statistically combining maps of old and recently active landslides with maps of geology and ground slope. Computed as a continuous variable at $30-\mathrm{m}$ resolution, an index of relative susceptibility to deep-seated landsliding is estimated for individual geologic map units as the areal percentage of terrain occupied by old landslides, adjusted by slope gradient and the spatial frequency of recent landslides. The resulting susceptibility map indicates that, although most of the OaklandBerkeley area is unlikely to host a deep-seated landslide, over one-fifth of the area of residential housing on hillsides has substantial potential for this type of slope instability. Using similar methods, susceptibility maps could be prepared for the entire San Francisco Bay region or, moreover, anywhere the three components - geology, landslide locations, and slope gradient - are available as digital spatial data. Such susceptibility maps have various applications to public policy aimed at mitigating the landslide hazard.

\section{Introduction}

This chapter addresses the relative predisposition, or susceptibility, of the urban Oakland-Berkeley area and its surrounding hillsides to deep-seated landsliding. Such landslides might be induced by a major earthquake, as discussed further by Miles and Keefer (see ch. 4, this report) or, more frequently, by an accumulation of soil moisture from an exceptionally rainy winter or succession of severe winters (see Wilson, ch. 1, this report). The resulting deep-seated landslides differ significantly from the shallow failures discussed by Schmidt and Sobieszczyk (see ch. 3, this report).

Deep-seated landslides have long posed a hazard across the San Francisco Bay region, where they routinely cause economic losses (Harding, 1969; Nilsen and Turner, 1975; Nilsen and others, 1976a; Coe and others, 1999) and, occasionally, fatalities (Cotton and Cochrane, 1982). Such losses can be reduced by narrowing the uncertainty that surrounds the potential locations of future landslides, the ultimate objective of this chapter. The slope-instability scenario modeled here does not predict, in either time or space, specific landslides resulting from a particular earthquake, storm, or succession of storms or stormy seasons. Rather, the resulting susceptibility map (pl. 1) indicates the likely locations and relative severity of future landsliding. The map was prepared in a geographic information system (GIS) from the numerical model developed by Pike and others (2001); see Pike and others (2001) for further background, details, illustrations, and references.

\section{The Landslide Hazard}

"Landslides" in this chapter mostly refers to large, deep failures, each of which results in a deposit that extends at least $60 \mathrm{~m}$ in the longest horizontal dimension and covers from less than a hectare to as much as several square kilometers. "Deep-seated landslides" in this chapter excludes shallow failures that may mobilize as debris flows; the term, which includes earth and rock slumps, earth and rock block slides, and earth flows (Varnes, 1978), roughly corresponds to the "deep, slow landslides" and the larger "earth flows" in figure 1-3 of Wilson (ch. 1, this report). Such landslides, which involve surficial deposits and bedrock down to depths of a few meters to tens of meters, distort the ground surface when they move and may remain as recognizable masses for thousands of years (Nilsen and Wright, 1979; Keefer and Johnson, 1983; Wentworth and others, 1997). Although these large landslides usually move slowly and, thus, seldom threaten life directly, they can cause great property damage. When they move - usually in response to increased pore-water pressure, earthquake shaking, or changes to topography brought about by grading - deep-seated landslides can offset roads, destroy foundations, break underground pipes, and override property (Harding, 1969).

Damaging landslides of this type in the San Francisco Bay region are episodic and difficult to predict. The 1989 Loma Prieta earthquake generated 20 large failures that were mostly within presumed-dormant older landslides (Keefer and others, 1998), as well as thousands of small landslides near the epicenter in the Santa Cruz Mountains, about $90 \mathrm{~km}$ 
south-southeast of Oakland. Several deep-seated landslides were reactivated during the El Niño winter of 1997-98 (Pike and others, 1998). One of these was a segment of an ancient landslide complex underlying the rural village of La Honda, about $55 \mathrm{~km}$ south of Oakland in the Santa Cruz Mountains (Jayko and others, 1998). Houses on the old landslide had begun to deform even before the heaviest rainfall in early February 1998, when movement accelerated from millimeters to centimeters per day, and waning of the prolonged 1997-98 rainy season did not end the hazard (Wells and others, 2005, 2006). We speculate that the water table, which in some areas remained high or continued to rise, contributed to this and subsequent failures. In March 1998, part of the massive dormant Mission Peak landslide in Alameda County, $45 \mathrm{~km}$ southeast of Oakland, was reactivated (Rogers, 1998; Coe and others, 1999). One month later, a much smaller earth flow near the town of Aromas, just south of the Santa Clara County line about $115 \mathrm{~km}$ southeast of Oakland, remobilized, cutting the pipelines supplying natural gas to 95 percent of Santa Cruz County residents (fig. 2-1; see also, http://landslides.usgs.gov/ recent/archives/1998sanbenito.php).

\section{Delimiting the Hazard}

Maps that show existing landslides are important in predicting the locations of future slope instability (Nilsen and others, 1976b; Nilsen and Wright, 1979; Cotton and Cochrane, 1982; Wieczorek, 1984; Haydon, 1995; Wilson and others, 2003). Such inventory maps do not necessarily distinguish fresh slope movements, but in any one year some of the mapped landslides — or, more commonly, portions of some of them-may become active (Jayko and others, 1998; Keefer and others, 1998). New landslides also occur in areas that have not failed previously, especially where topography has been modified by grading (Wentworth and others, 1987). The landforms and material deposits created by large landslides, which are prominent in the hills in and east of Oakland (Radbruch and Weiler, 1963; Radbruch and Case, 1967; Radbruch, 1969; Nilsen and Turner, 1975), are mapped extensively in the San Francisco Bay region. Over 70,000 historic and prehistoric, apparently dormant, landslides (referred to herein as "old") are inventoried on mostly 1:24,000-scale maps that collectively cover the entire region (Nilsen and Wright, 1979; Pike, 1997).

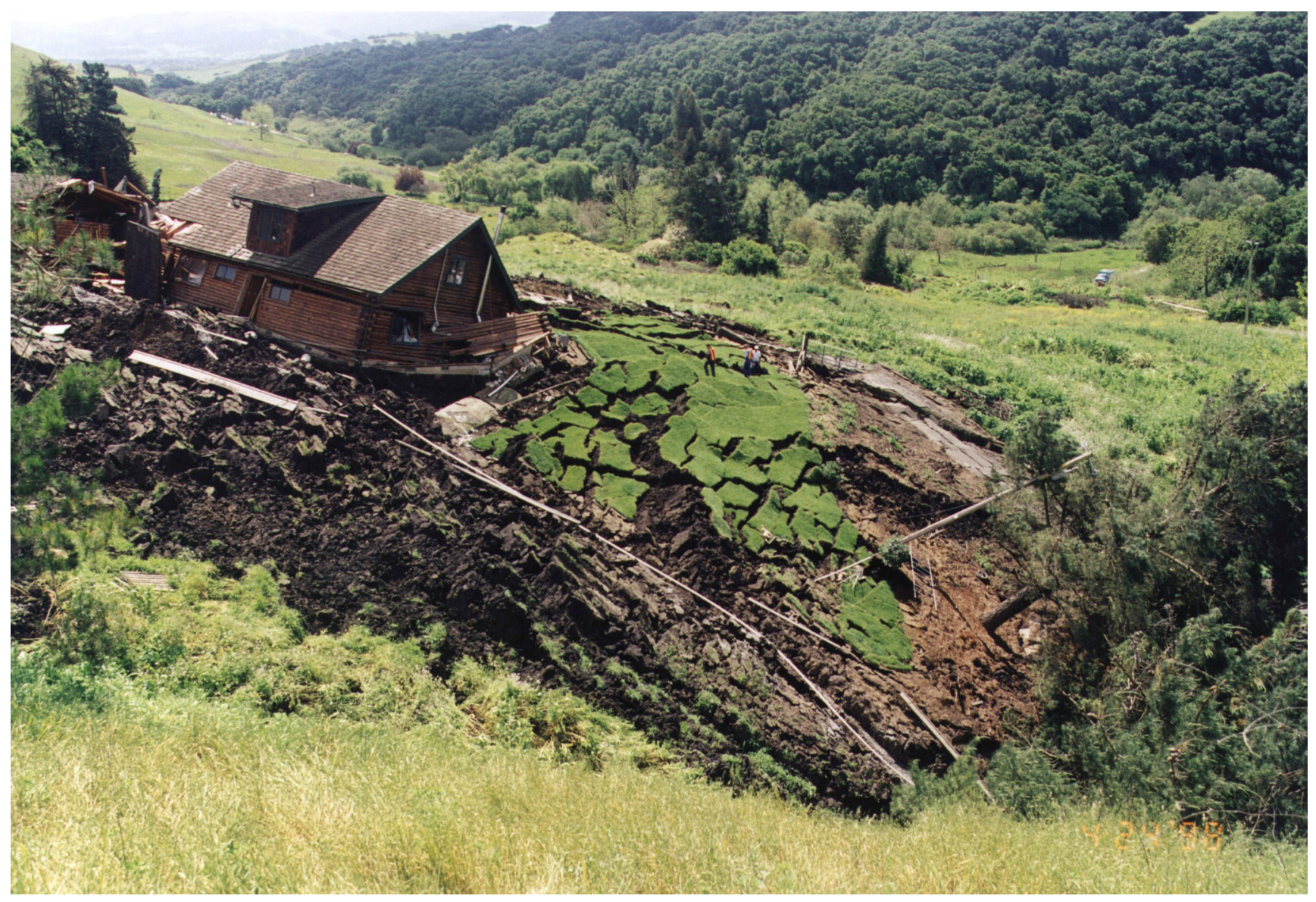

Figure 2-1. Reactivated deep-seated landslide (earth flow) near town of Aromas, northern San Benito County, that cut natural gas service to 60,000 Santa Cruz County residents on April 23, 1998. Photograph by W.R. Cotton. 
Although an inventory map reveals the extent of past slope movement and, thus, the probable locus of some future activity within existing landslides, it does not indicate the likelihood of failure within the much larger area that lies between mapped landslides (Brabb, 1995). Estimating the hazard continuously over a region requires spatial data on other contributing factors, particularly geology and slope gradient (Blanc and Cleveland, 1968; Radbruch and Crowther, 1970, 1973). Building on the work of these authors, Brabb and others (1972) combined the distribution of old landslide deposits, bedrock map units, and estimates of ground slope to create a semiquantitative map of landslide susceptibility. Nilsen and Wright (1979) compiled a similar but more generalized map for nine counties in the San Francisco Bay region (all but Santa Cruz County).

Improvements in computer technology enabled Newman and others (1978) to test a grid-cell implementation of the susceptibility-mapping method of Brabb and others (1972). Their resulting map for a small area in San Mateo County presaged by several years the GIS capabilities that now permit the three components - geology, old landslide deposits, and slope gradient - to be combined quantitatively, and to do so rapidly over large areas. Plate 1 (see also, Pike and others, 2001) contains such a GIS-generated susceptibility map for the OaklandBerkeley area. Its method of preparation, outlined in the sections that follow, provides an empirical model for generating detailed county-scale landslide-susceptibility maps for the San Francisco Bay region (Pike and Sobieszczyk, 2002).

\section{A New Model of Landslide Susceptibility}

Pike and others (2001) refined the statistical method of Brabb and others (1972) in several respects and implemented it within a GIS to yield a landslide-susceptibility index as a continuous variable. Before calculating susceptibility, defined by Brabb and others (1972) as the spatial frequency of existing landslide deposits (within each geologic unit) for different values of slope gradient, the method of Pike and others (2001) divides gradient into much finer gradient intervals than the six used by Brabb and others (1972). The procedure then assigns the resulting values of susceptibility to small grid cells rather than broad zones of equal slope. Finally, whereas Brabb and others (1972) modeled the high susceptibility expected within existing landslides by assigning one value, the maximum, to an entire deposit, Pike and others (2001) used the frequency of recent failures to calculate a range of high susceptibility values within the old deposits.

To prepare the map for this report (pl. 1), the sevenquadrangle Oakland-Berkeley study area was divided into nearly a million square cells that are nominally $30 \mathrm{~m}$ on a side, which is the cell spacing of the elevation array (Graham and Pike, 1998a). Raster-grid maps at this resolution were then created for the geology, the old landslide deposits, the point locations of recent landslides, and the slope gradient (see fig. 2-2). From the cell values on these four maps, the index of relative susceptibility was calculated automatically by a two-step algorithm written in Arc Macro Language and executed in the GRID module of the ArcInfo GIS (version 7.1.1 running on a SUN/Solaris UNIX computer).

\section{Geology}

Hillside materials are a major, if not the dominant, site control over the larger and deeper types of slope failure worldwide (see, for example, Van Den Eeckhaut and others, 2006, as well as older references in Pike and others, 2001). In the San Francisco Bay region, the prevalence of landsliding varies considerably with rock type and geologic structure (Radbruch and Weiler, 1963; Brabb and others, 1972; Nilsen and others, 1976b; Haydon, 1995). Geology also can influence the likelihood of shallow failure (see Schmidt and Sobieszczyk, ch. 3, this report). The Oakland-Berkeley area is underlain by highly diverse lithologies (Graymer, 2000): the upland areas in and east of the city of Oakland, which occupy two-thirds of the total study area, comprise 100 bedrock units (see fig. 2-2A), and all but eight of these units contain landslide deposits; the remaining one-third of the area, which is largely flatland terrain to the west, is underlain by 20 unconsolidated Quaternary units that contain few old landslides (table 2-1).

\section{Old Landslide Deposits}

Pike and others (2001) applied their susceptibility model to 6,714 landslide deposits in the study area. These deposits are from a landslide inventory compiled at 1:24,000 scale for much of the San Francisco Bay region by Nilsen $(1973,1975)$ from the stereoscopic interpretation of aerial photographs. Most landslides are on hillsides northeast of the built-up parts of Oakland, and they cover about one-fifth of the upland area. The landslides cluster in elongate patterns that align with the northwest-southeast-trending structural-topographic grain, a regional trend clearly evident in the map on plate 1 and in figures $2-2 \mathrm{~A}$ and $2-2 \mathrm{D}$ (but less so in figures $2-2 \mathrm{~B}$ and $2-2 \mathrm{C}$ ). Types of movement and triggering causes of instability for individual landslides were not documented by Nilsen (1973, 1975). Estimated times of initial movement may range from 35 years ago to possibly hundreds of thousands of years before present; however, elevated precipitation in the late Pleistocene (approx 14,000-10,000 yr B.P.) has been hypothesized to have triggered abundant smaller, shallow landslides around the San Francisco Bay region (Reneau and others, 1986).

Nilsen $(1973,1975)$ outlined on 1:24,000-scale topographic maps those areas large enough to be recognizable as landslides on (mainly) 1:20,000-scale aerial photographs, according to diagnostic criteria accepted at the time. Most of the mapped landslides are deposits only, although portions of some source areas upslope from the deposit also may have 

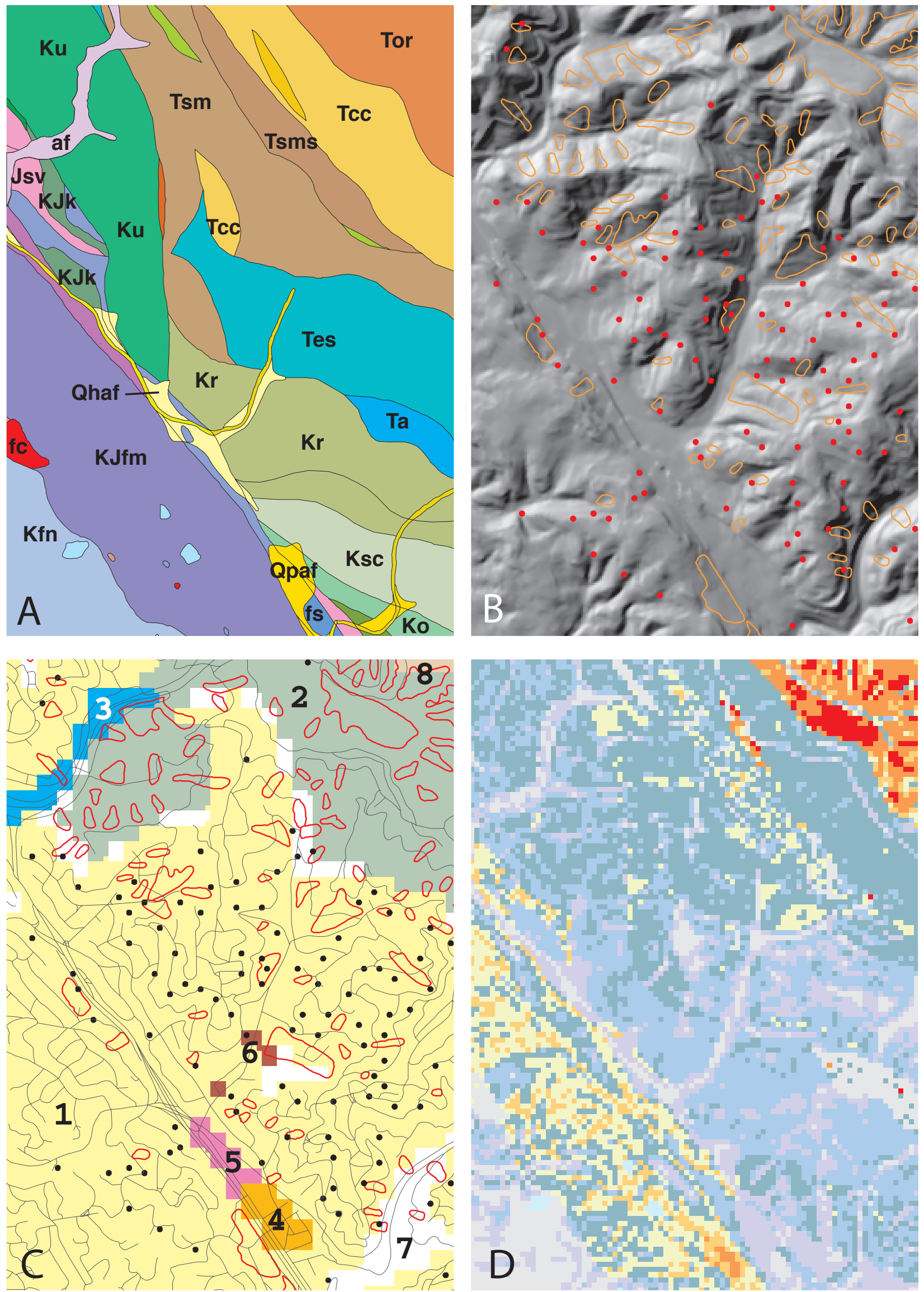
been included. Nilsen mapped most of the larger landslide masses as multilobed complexes coalesced from smaller deposits. Field descriptions of landslides in the Oakland area (see, for example, Radbruch and Weiler, 1963; Radbruch and Case, 1967; Radbruch, 1969; Keefer and Johnson, 1983) suggest that most of the landslides recognized by Nilsen are earth slumps, rock slumps, earth block slides, rock block slides, or earth flows, according to the taxonomy of Varnes (1978). Because small earth flows tend to be shallow (Keefer and Johnson, 1983), the "deep-seated" descriptor commonly applied to the Nilsen inventory is not exact.

In the absence of a more detailed inventory (Wills and McCrink, 2002), the reconnaissance mapping of Nilsen provides the only landslide data from which a demonstration of the susceptibility model can be made for the designated study area. Only recently have limitations of the Nilsen inventory been considered sufficient to prompt field verification or systematic remapping to current standards of completeness. Landslides currently (2008) are being remapped by the California Geological Survey, but the mapping does not cover the entire Oakland-Berkeley study area (for example, Wilson and others, 2003, p. 32 and plate 2.1). Although Nilsen's 30-yearold maps still are used to guide general planning and hazard assessment (local consultants regard them as a starting point for site investigations), landslide maps prepared from reconnaissance photointerpretation are not suited for use either in the adjudication of compensation for landslide losses or in other applications that depend upon detailed knowledge of individual failures.

The hazard scenario for deep-seated landsliding in this report requires neither a landslide-by-landslide engineering analysis involving detailed field study (Wills and McCrink, 2002) nor a Varnes (1978) categorization of each confirmed landslide. Although the Nilsen mapping, like all photo-based inventories, excludes some actual landslides but includes other areas that are not landslides, the statistical model of susceptibility resulting in plate 1 minimizes these two self-canceling sources of error. Precise location, area, and mode of failure of each landslide are not critical to estimating susceptibility. The model takes advantage of the most reliable property of the Nilsen data set, its approximate areal coverage of deep-seated landslides for different geologic map units across a large area.

\section{Recent Landslides}

A population of recent landslides is needed to estimate the higher susceptibilities likely to prevail within older deposits. While landslide activity has continued in the study area since Nilsen's mapping, the regional inventorying that would yield a spatially unbiased population of new landslides has not. The best recorded features from which to refine susceptibility estimates are 1,192 post-1967 landslides that have damaged the built environment (Nilsen and Turner, 1975; Nilsen and others, 1976a; Coe and others, 1999; Graymer and Godt, 1999; see also, sources cited in Pike and others, 2001). These rainfallinduced landslides largely are failures of cut-and-fill grading in urbanized terrain, commonly in otherwise low-susceptibility materials; 183 (15\%) of them have reactivated dormant deposits mapped by Nilsen (1975). Because outlines of most of the 1,192 landslides are not recorded (they probably were too small to be shown effectively at 1:24,000 scale), Pike and others (2001) compiled their locations as point data, one $30-\mathrm{m}$ grid cell per landslide.

\section{Slope Gradient}

Configuration of the land surface (fig. 2-2B) both reflects and influences the mass-wasting processes that shape local

Figure 2-2. Maps showing elements of susceptibility to deep-seated landsliding, as depicted on map on plate 1. Area shows part of north Oakland; same 9.6- $\mathrm{km}^{2}$ area is covered in all four figures (A-D); width is about $2.6 \mathrm{~km}$; Hayward Fault Zone passes through southwestern part of area shown, separating steep terrain (to east) from lower sloping terrain (to west). See table 2-1 for spatial frequencies (over entire study area) of 19 map units shown here, old landslide deposits on these units, and post-1967 landslides within units. A, Geology, simplified from Graymer (2000). Relevant map units listed in table 2-1 (see Graymer, 2000, for complete map-unit descriptions): af, artificial fill; fc, Franciscan Complex (chert blocks in mélange); fs, Franciscan Complex (graywacke and meta-graywacke blocks in mélange); Kfn, Franciscan Complex (sandstone of the Novato Quarry terrane of Blake and others, 1984); KJfm, Franciscan Complex mélange; KJk, Knoxville Formation; Ko, Oakland Conglomerate; Kr, Redwood Canyon Formation; Ksc, Shephard Creek Formation; Ku, Great Valley sequence (undifferentiated); Jsv, keratophyre and quartz keratophyre; Qhaf, Holocene alluvial fan and fluvial deposits; Opaf, Pleistocene alluvial fan and fluvial deposits; Ta, unnamed glauconitic sandstone unit; Tcc, Claremont chert of Graymer (2000); Tes, Escobar Sandstone of Weaver (1953); Tor, Orinda Formation; Tsm, unnamed glauconitic mudstone unit; Tsms, interbedded siltstone and sandstone in unnamed glauconitic mudstone unit. Hayward Fault Zone strikes north-northwest along east edge of unit KJfm. B, Old landslide deposits (orange outlines; Nilsen, 1973, 1975) and post-1967 landslides (red dots; Nilsen and Turner, 1975; Nilsen and others, 1976a; Coe and others, 1999; Graymer and Godt, 1999) overlain on shaded-relief map (from 10-m DEM). C, Old landslide deposits (red outlines) and post-1967 landslides (black dots) overlain on 1995 land-use map (compiled at 100-m resolution by Perkins and Chuaqui, 1996). Land-use categories: 1, residential (yellow); 2, forest (green); 3, major highway (blue); 4, commercial (orange); 5, school (magenta); 6, public institution (brown); 7, vacant-mixed use (white); 8, scrub vegetation (tan). Roads shown in screened black. D, Susceptibility to deep-seated landsliding, extracted from map on plate 1 (see also, Pike and others, 2001). Index of susceptibility (computed at 30-m resolution) ranges from lowest (light gray) to highest (red). Values of relative susceptibility: light gray, less than 0.01; lavender, 0.01-0.049; light blue-green, 0.05-0.099; dark blue-green, 0.10-0.199; yellow, 0.20-0.299; light orange, 0.30-0.399; dark orange, $0.40-0.549$; red, 0.55 and higher. Susceptibility values $0.05-0.199$ predominate in this area. 
Table 2-1. Spatial frequencies of geologic units, old landslide deposits, and post-1967 landslides for 28 of 120 units in Oakland-Berkeley area, California, listed in descending order of mean spatial-frequency values for landslide deposits. Detailed frequency distributions for old landslide deposits arrayed by slope gradient are shown for two contrasting units in figure 2-2.

\begin{tabular}{|c|c|c|c|c|c|c|}
\hline \multicolumn{3}{|c|}{ GEOLOGIC UNIT } & \multicolumn{2}{|c|}{ OLD LANDSLIDE DEPOSITS } & \multicolumn{2}{|c|}{ POST-1967 LANDSLIDES } \\
\hline $\begin{array}{c}\text { Map } \\
\text { symbol }^{1}\end{array}$ & Name $^{1}$ & $\begin{array}{l}\text { All cells } \\
\text { (total num- } \\
\text { ber of } 30-m \\
\text { grid cells) } \\
\end{array}$ & $\begin{array}{l}\text { Landslide } \\
\text { cells } \\
\text { (number of } \\
\text { grid cells) }\end{array}$ & $\begin{array}{c}\text { Mean spatial } \\
\text { frequency } \\
\text { (landslide } \\
\text { cells / all cells) }\end{array}$ & $\begin{array}{c}\text { Total } \\
\text { number } \\
\text { (one grid cell } \\
\text { per landslide) }\end{array}$ & $\begin{array}{l}\text { Number } \\
\text { within old } \\
\text { landslide } \\
\text { deposits } \\
\end{array}$ \\
\hline $\mathrm{Kfa}$ & Franciscan Complex (sandstone of Alcatraz terrane) ${ }^{2}$ & 1,002 & 820 & 0.82 & 6 & 6 \\
\hline Tn? & Neroly Sandstone $(?)^{2}$ & 1,786 & 1,120 & 0.63 & 2 & 2 \\
\hline Th? & Hambre Sandstone $(?)^{2}$ & 2,514 & 1,428 & 0.57 & 1 & 0 \\
\hline Tus & Unnamed Tertiary sedimentary and volcanic rocks ${ }^{2}$ & 99,233 & 35,956 & 0.36 & 168 & 40 \\
\hline Tmll & Mulholland Formation (lower member) ${ }^{2}$ & 18,812 & 5,518 & 0.29 & 85 & 15 \\
\hline Tmlu & Mulholland Formation (upper member) ${ }^{2}$ & 14,578 & 4,158 & 0.29 & 70 & 12 \\
\hline Tor & Orinda Formation & 35,166 & 9,682 & 0.28 & 83 & 27 \\
\hline $\mathrm{Tbr}$ & Briones Sandstone (sandstone, siltstone, conglomerate, shell breccia) ${ }^{2}$ & 32,548 & 8,723 & 0.27 & 29 & 5 \\
\hline KJfm & Franciscan Complex mélange & 12,212 & 2,559 & 0.21 & 66 & 19 \\
\hline Th & Hambre Sandstone ${ }^{2}$ & 26,341 & 3,454 & 0.13 & 7 & 0 \\
\hline Tsm & Unnamed Tertiary glauconitic mudstone & 3,389 & 438 & 0.13 & 24 & 0 \\
\hline Tsms & Siltstone and sandstone (unnamed Tertiary glauconitic mudstone unit) ${ }^{3}$ & 362 & 46 & 0.13 & 3 & 0 \\
\hline Tn & Neroly Sandstone ${ }^{2}$ & 23,440 & 2,753 & 0.12 & 13 & 1 \\
\hline Tcc & Claremont chert of Graymer (2000) & 10,590 & 1,177 & 0.11 & 4 & 0 \\
\hline Ksc & Shephard Creek Formation & 5,675 & 508 & 0.09 & 12 & 1 \\
\hline $\mathrm{KJk}$ & Knoxville Formation & 8,164 & 663 & 0.08 & 25 & 1 \\
\hline Jsv & Keratophyre and quartz keratophyre (above ophiolite) & 15,627 & 1,212 & 0.08 & 50 & 6 \\
\hline $\mathrm{Ku}$ & Great Valley sequence (undifferentiated) & 12,706 & 965 & 0.08 & 35 & 2 \\
\hline $\mathrm{Kr}$ & Redwood Canyon Formation & 27,503 & 1,697 & 0.06 & 27 & 1 \\
\hline Tes & Escobar Sandstone & 2,513 & 141 & 0.06 & 43 & 3 \\
\hline fs & Franciscan Complex (graywacke and meta-graywacke blocks in mélange) & 3,441 & 109 & 0.03 & 9 & 1 \\
\hline $\mathrm{Ta}$ & Unnamed Tertiary glauconitic sandstone ${ }^{3}$ & 163 & 3 & 0.02 & 4 & 0 \\
\hline Qpaf & Pleistocene alluvial fan and fluvial deposits ${ }^{4}$ & 61,867 & 1,010 & 0.02 & 87 & 0 \\
\hline Kfn & Franciscan Complex (sandstone of Novato Quarry terrane) & 7,879 & 122 & 0.02 & 27 & 1 \\
\hline Ko & Oakland Conglomerate & 20,921 & 301 & 0.01 & 6 & 0 \\
\hline fc & Franciscan Complex (chert blocks in mélange) ${ }^{3}$ & 323 & 1 & 0.00 & 0 & 0 \\
\hline \multirow{3}{*}{$\begin{array}{l}\text { Qhaf } \\
\text { af }\end{array}$} & Holocene alluvial fan and fluvial deposits ${ }^{4}$ & 125,014 & 254 & 0.00 & 38 & 0 \\
\hline & Artificial fill ${ }^{4}$ & 65,934 & 15 & 0.00 & 5 & 0 \\
\hline & All 120 geologic units ${ }^{5}$ & 969,003 & 116,360 & 0.12 & 1,192 & 183 \\
\hline
\end{tabular}

1 Unit names and map symbols from Graymer (2000).

2 Geologic unit mentioned in text but not shown on figure 2-1.

3 Hillside unit comprising fewer than 450 total cells, so that distribution of spatial frequency (fig. 2-2) may be less continuous than that of other units.

4 Quaternary unit in flatland terrain (less susceptible than most hillside units in study area).

5 Values shown are for entire study area (see Pike and others, 2001, table 1), not just the 28 units shown here. 
hillsides (Radbruch and Weiler, 1963; Nilsen and others, 1976b; Nilsen and Wright, 1979; Dietrich and others, 1993; see also, Schmidt and Sobieszczyk, ch. 3, this report). Slope gradient, the most representative parameter of surface form, has long been considered a key control on deep-seated failure (for a recent analysis, see Van Den Eeckhaut and others, 2006). To evaluate the role of topography in deep-seated landsliding for the Oakland-Berkeley area, Pike and others (2001) calculated slope gradient for each 30-m grid cell. The data are from a map of the 10-county San Francisco Bay region (Graham and Pike, 1998b) derived from a digital elevation model (DEM), a nominally square matrix of terrain heights spaced herein at a constant 30-m interval (Graham and Pike, 1998a). To avoid calculating susceptibility at too fine a resolution (compared to the large size of most of the landslides), we did not use 10-m DEM data (available from http://bard.wr.usgs.gov/) because it offered no advantage other than providing a smoother appearing shaded-relief image for fig. 2-2B (the 10-m DEM was prepared from the same elevation contours as the $30-\mathrm{m}$ DEM and, thus, is not more accurate).

\section{The Susceptibility Model}

Overall susceptibility of a geologic map unit to deepseated landsliding can be expressed numerically as the percentage of the area of the unit that contains existing landslide deposits (Brabb and others, 1972). This percentage, or mean spatial frequency, is highly variable. Computed herein as the number of 30-m cells in landslide deposits divided by the total number of cells in the unit (table 2-1), mean spatial frequency in the Oakland-Berkeley area ranges from 82 percent (in the most susceptible unit) to less than one percent (in 26 different units). The most susceptible formations are bedrock units in the Oakland-Berkeley Hills; the unconsolidated units on the flatlands are far less susceptible. Because the occurrence of landsliding within each geologic unit varies locally with steepness of the terrain, Pike and others (2001) refined the wholeunit spatial frequencies of all 120 map units according to the slope gradient (calculated from the 30-m DEM).

An index of relative susceptibility for each 30 -m grid cell was estimated empirically for each geologic unit from a graph that plots the spatial frequency of old landslide deposits as a function of slope gradient, in $1^{\circ}$ increments (fig. 2-3); cells were assigned susceptibility values directly from the graphs. For example, in the Orinda Formation, where 29 percent of the cells that slope $10^{\circ}$ are located on old landslide deposits, all cells in the unit that have a slope of $10^{\circ}$ are assigned that same susceptibility of 0.29. By contrast, in the Claremont chert of Graymer (2000), only 5 percent of the cells in the $10^{\circ}$ slope interval lie on mapped landslide masses, and so a susceptibility of 0.05 is assigned to all $10^{\circ}$-sloping cells in the unit. This procedure, repeated for all 120 geologic map units and for each $1^{\circ}$ interval of slope gradient, resulted in final values of relative susceptibility for all cells not underlain by old land- slide masses (accounting for nearly 90 percent of the study area) and interim values for cells on old landslides.

To estimate the higher level of hazard likely to characterize the remaining 10 percent of the Oakland-Berkeley area that lies within old landslide deposits, the model of Pike and others (2001) raised by a factor of 1.33 all interim values of susceptibility calculated for grid cells within deposits. This multiplier $(\boldsymbol{a})$ is derived from the comparative frequency of local post-1967 landslides:

$$
\boldsymbol{a}=\left(N_{l s} / A_{l s}\right) /\left(N_{n l s} / A_{n l s}\right)
$$

where $N_{l s}$ and $N_{n l s}$ are the numbers of recent landslides within and outside of old landslide deposits, respectively, and $A_{l s}$ and $A_{n l s}$ are the areas (in numbers of cells) of old landslide deposits and the terrain between them. This 33 percent increase is of the same magnitude previously cited for the observed incidence of new failures within old deposits in the East Bay, where, in the more susceptible geologic map units, about 55 to 70 percent of recent landslides occurred on old landslides (Nilsen and others, 1976b, p. 19).

The quality, or predictive power, of a susceptibility model for large landslides in the San Francisco Bay region is difficult to judge by comparison with recent landsliding, which is not sufficiently documented in undisturbed (undeveloped) terrain to provide robust test results. Two statistical evaluations detailed in Pike and others $(2000,2001)$ suggested that the model generates reasonable first-order estimates of relative susceptibility, both within and outside the region in which the procedure was developed. Also, some parts of the areas in the East Bay hills identified as active slow-moving landslides by Hilley and others (2004) from a spaceborne imaging technique coincide with areas of moderate to very high susceptibility in the map on plate 1. However, only a future occurrence of the likely scenario responsible for triggering deep-seated landslides in this area - a large earthquake or an extended period of rainfall — will truly test the spatial predictions made here.

\section{The Susceptibility Map}

Values of the susceptibility index for all 969,000 30-m cells between and within old landslide deposits are combined in the map on plate 1 . The base-map information on topography, drainage, and culture is from Aitken (1997). Overall, the map resembles its only predecessor covering the study area, the regional (1:125,000-scale) slope-stability map of Nilsen and Wright (1979) but is much more detailed. The maps on plate 1 and in figure 2-2D show the continuous range of relative susceptibility, in decimal units, divided into eight colorcoded intervals that broaden with increasing susceptibility and decreasing number of cells. The unequal intervals, which are based on the frequency distribution of all susceptibility values (ranging from zero to 1.33), yield a balanced-appearing map that emphasizes the spatial variability of the index. 
No exact level of hazard is implied by these eight intervals, only an increasing likelihood of deep-seated landsliding (represented on the map by increasing warmth of tone and saturation of color, from gray through blue to red). Designating particular values or intervals of the susceptibility index as "safe" or "dangerous" is arbitrary and subjective and remains a matter of interpretation, as no direct means of calibration is available at this time. However, because field studies long have identified such geologic map units as the Briones Sandstone and the Orinda Formation as being prone to landsliding (see, for example, Radbruch and Case, 1967; Radbruch, 1969; Keefer and Johnson, 1983), we believe that susceptibility values that are at least as low as 0.20 (yellow on the map) indicate areas of potential slope instability, depending on the strength and duration of triggering conditions. Dense clusters of index values that exceed 0.30 (light orange on the map) almost certainly contain potentially unstable areas.

The spatial patterns on the maps on plate 1 and in figure $2-2 \mathrm{D}$ are not random; rather, they reveal a systematic proclivity to landsliding that is controlled primarily by contrasts in lithology and, secondarily, by the underlying fault-induced structure and the resulting northwest-trending topography. Susceptibility values that exceed 0.30 are conspicuous in steep terrain underlain by formations known from field observation (Radbruch, 1969; Nilsen and others, 1976b) to host large landslides; prominent among them are the Briones Sandstone and the Orinda and Mulholland Formations, as well as the (widespread) unnamed Tertiary sedimentary and volcanic rocks unit (Tus, table 2-1). Table 2-2 shows the percentage distribution of landslide susceptibility for both the entire study area and the more susceptible terrain underlain by hillside geologic units. Relative susceptibility for 19 to 30 percent of the greater Oakland-Berkeley area exceeds 0.30 ; slightly lower values, in the $0.10-0.29$ range, are equally common. Among the most susceptible locations on the map on plate 1 are San Pablo Ridge, much of Sobrante Ridge, Siesta Valley, upland areas west of Moraga Valley and between Moraga and Siesta Valleys, the slopes between Rocky Ridge and Bollinger Canyon, and hilly parts of Richmond and El Cerrito near the Hayward Fault Zone. Most, but not all, locations that have the highest potential for landsliding are steep and thinly settled and, thus, commonly are in parkland or in areas least likely to be developed.

A potential public-safety issue is the location of residential dwellings in terrain highly susceptibility to landsliding (pl. 1 and fig. 2-2C). A GIS comparison of land-use data from Perkins and Chuaqui (1996) with the map (pl. 1)

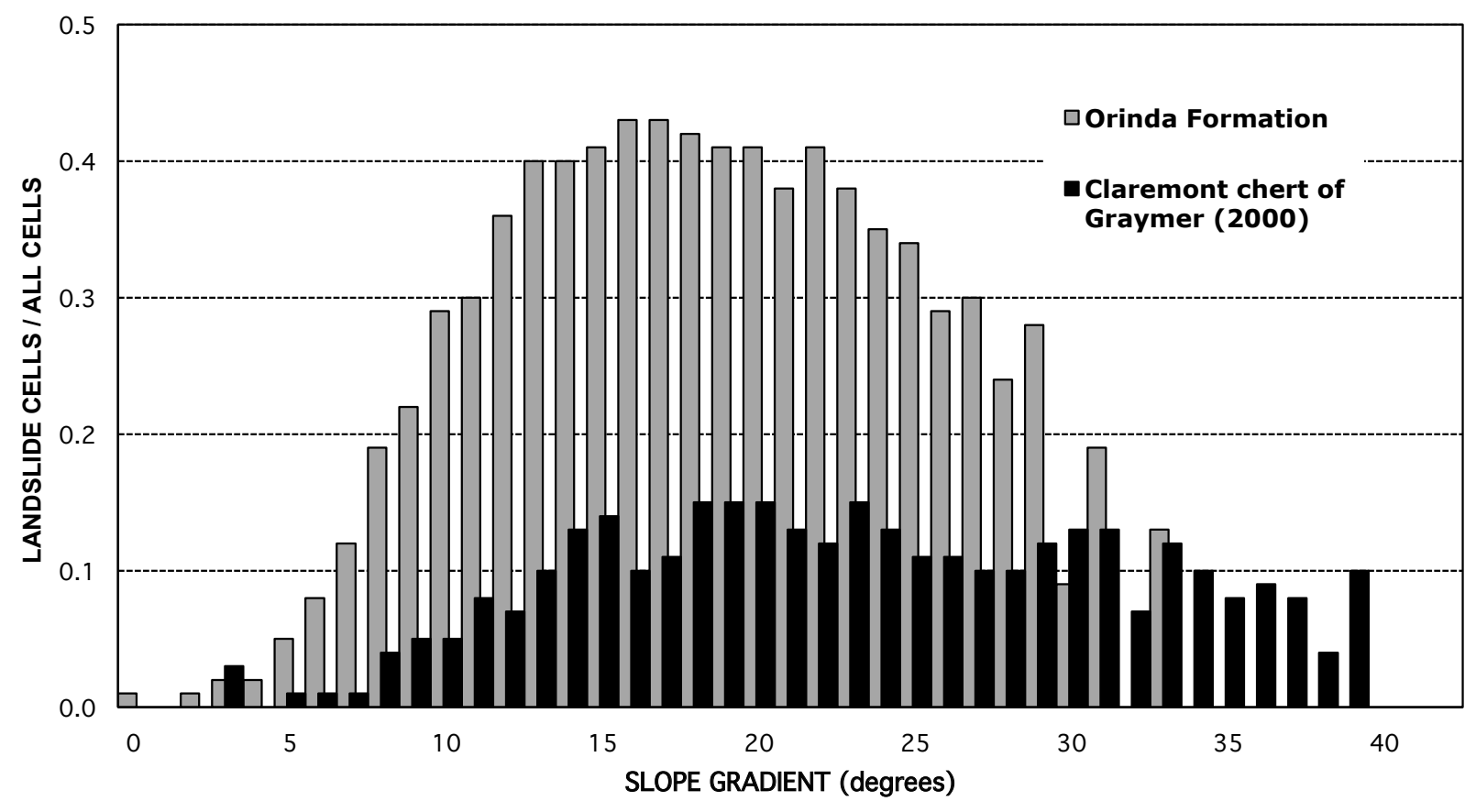

Figure 2-3. Plot showing contrasts, by lithology and slope gradient, in susceptibility to deep-seated landsliding of two Oakland-area geologic units. Susceptibility, in $1^{\circ}$ slope intervals, is expressed by number of $30-\mathrm{m}$ grid cells on old landslide deposits divided by all cells in unit. The Claremont chert of Graymer (2000) (black) generally is much less susceptible than clay-rich sedimentary rocks of the Orinda Formation (gray) but sustains deep-seated landsliding on steeper slopes. Mean spatial frequencies of old landslide deposits are, respectively, 0.11 and 0.28 . Number of grid cells in each bar, not shown, is highly variable and diminishes with increasing slope. To compute values shown on map on plate 1, digital file containing similar susceptibility/slope-gradient information was generated for each of 120 geologic units (see also, Pike and others, 2001, table 1). 
Table 2-2. Geographic distribution of modeled susceptibility values within study area (see pl. 1).

\begin{tabular}{|c|c|c|}
\hline$\underline{\text { Index of }}$ & \multicolumn{2}{|c|}{ Percentage of study area } \\
\hline Susceptibility & $\begin{array}{c}\text { Entire } \\
\text { study area }\end{array}$ & $\begin{array}{c}\text { Hillside geologic } \\
\text { units only }\end{array}$ \\
\hline$<0.01$ & 36 & 9 \\
\hline $0.01-0.049$ & 16 & 15 \\
\hline $0.05-0.099$ & 10 & 14 \\
\hline $0.10-0.199$ & 13 & 21 \\
\hline $0.20-0.299$ & 7 & 12 \\
\hline $0.30-0.399$ & 6 & 9 \\
\hline $0.40-0.549$ & 9 & 14 \\
\hline$\geq 0.55$ & 4 & 7 \\
\hline
\end{tabular}

Table 2-3. Geographic distribution of modeled susceptibility values for land occupied by residential housing within study area. ${ }^{1}$

\begin{tabular}{|c|c|c|}
\hline Index of & \multicolumn{2}{|c|}{ Percentage of area in residential housing } \\
\hline Susceptibility & $\begin{array}{c}\begin{array}{c}\text { Entire } \\
\text { study area }\end{array} \\
\end{array}$ & $\begin{array}{l}\text { Hillside geologic } \\
\text { units only }\end{array}$ \\
\hline$<0.01$ & 48 & 18 \\
\hline $0.01-0.049$ & 22 & 20 \\
\hline 0.05-0.099 & 7 & 14 \\
\hline $0.10-0.199$ & 8 & 16 \\
\hline $0.20-0.299$ & 4 & 9 \\
\hline $0.30-0.399$ & 4 & 9 \\
\hline $0.40-0.549$ & 4 & 9 \\
\hline$\geq 0.55$ & 2 & 5 \\
\hline
\end{tabular}

${ }^{1}$ Land - use data from Perkins and Chuaqui (1996). reveals the percentage of area classified as residential housing in each of the eight levels of landslide susceptibility, for both the entire study area and its more susceptible hillsides (table 2-3). Although most of the greater Oakland-Berkeley area lies within terrain having susceptibility-index values under 0.05 , 23 percent of the residential housing in hillside areas, which covers nearly $32 \mathrm{~km}^{2}$, is situated in terrain ranked as 0.30 or higher. One of the larger concentrations of high-susceptibility values in the built environment is located on the eastern slopes of Las Trampas Ridge in the town of Danville, west of San Ramon Valley High School. This residential area was mapped by Nilsen $(1973,1975)$ as an extensive landslide complex. The underlying rocks are queried map units (Tn?, Th?) that appear to be the otherwise low-susceptibility Neroly and Hambre Sandstones (table 2-1; see also, Graymer, 2000).

The map on plate 1 is statistical and must be interpreted accordingly: most locations on the map that have high values of the susceptibility index are more likely to host landslides than the locations that have low values, but the high-susceptibility locations almost certainly include areas that are not hazardous. In addition, and more germane to public safety, most areas on the map showing low susceptibility, although less prone to landsliding than areas of high values, are not without hazard. Some low-susceptibility locales slope steeply or are subject to other types of landslide activity. For example, landslide deposits less than $60 \mathrm{~m}$ in the longest dimension, which were not included in the inventory on which this map (pl. 1) is based, are common throughout the study area. Many of these small landslides may be debris flows (see ch. 3, this report). Also, because landslide crowns and head scarps were not mapped by Nilsen (1973) and, thus, are not incorporated into the susceptibility model, terrain upslope of old landslide deposits may be more susceptible than is shown on the map. Finally, the locus of much future landsliding simply cannot be predicted; slopes commonly fail as a result of the unanticipated blocking of surface drainage or other consequences of hillside development, as well as from the seemingly random variation in landslideinitiating events and other slope processes.

\section{Applications}

The relative-hazard map (pl. 1) resulting from the deepseated landsliding scenario addressed in this chapter can assist the formulation of public policy for mitigating the effects of slope instability in the Oakland-Berkeley area. For example, the City of Berkeley incorporated the susceptibility map of Pike and others (2001) into the city's Disaster Mitigation Plan by combining the map with a parcel map and a database of parcel characteristics to estimate the slope-failure hazard for individual properties (available from http://map3.ci.berkeley. ca.us/). Among the prospective applications of the map on plate 1 are regional-scale land-use planning and zoning of undeveloped property, locating general routes for utilities lifelines and other urban and interurban infrastructure, roadmaintenance budgeting at municipal through state levels, and regional estimating for insurance underwriting. All such applications should consider not only the map on plate 1 but also the rainfall thresholds described by Wilson in chapter 1 (this report) and the maps that show landsliding induced by conditions other than those responsible for the large deepseated landslides analyzed here (see Schmidt and Sobieszczyk, ch. 3, this report; see also, Miles and Keefer, ch. 4, this report). This multiple-scenario approach to evaluating the potential for landsliding can be extended beyond the Oakland-Berkeley study site to any area for which the necessary components can be made available as spatial data.

\section{Acknowledgments}

Comments by Steve Ellen, Ed Harp, and Gerry Wieczorek improved earlier drafts of this chapter.

\section{References Cited}

Aitken, D.S., 1997, A digital version of the 1970 U.S. Geological Survey topographic map of the San Francisco 
Bay region: U.S. Geological Survey Open-File Report 97-500, 3 sheets, scale 1:125,000 [http://pubs.usgs.gov/ of/1997/of97-500].

Blake, M.C., Jr., Howell, D.G., and Jayko, A.S., 1984, Tectonostratigraphic terranes of the San Francisco Bay region, in Blake, M.C., Jr., ed., Franciscan Geology of Northern California: Pacific Section, Society of Economic Paleontologists and Mineralogists, v. 43, p. 5-22.

Blanc, R.P., and Cleveland, G.B., 1968, Natural slope stability as related to geology, San Clemente area, Orange and San Diego Counties, California: California Division of Mines and Geology Special Report 98, 19 p.

Brabb, E.E., 1995, The San Mateo County California GIS project for predicting the consequences of hazardous geologic processes, in Carrara, Alberto, and Guzzetti, Fausto, eds., International workshop, Geographical Information Systems in Assessing Natural Hazards, September 20-22, 1993, Perugia, Italy [Proceedings]: Dordrecht, Kluwer, p. 299-334.

Brabb, E.E., Pampeyan, E.H., and Bonilla, M.G., 1972, Landslide susceptibility in San Mateo County, California: U.S. Geological Survey Miscellaneous Field Studies Map MF-360, scale 1:62,500.

Coe, J.A., Godt, J.W., Brien, Dianne, and Houdre, Nicolas, 1999, Map showing locations of damaging landslides in Alameda County, California, resulting from 1997-98 El Niño rainstorms: U.S. Geological Survey Miscellaneous Field Studies Map MF-2325-B, scale 1:125,000 [http:// pubs.usgs.gov/mf/1999/mf-2325-b/].

Cotton, W.R., and Cochrane, D.A., 1982, Love Creek landslide disaster January 5, 1982, Santa Cruz County: California Geology, v. 35, no. 7, p. 153-157.

Dietrich, W.E., Wilson, C.J., Montgomery, D.R., and McKean, J., 1993, Analysis of erosion thresholds, channel networks, and landscape morphology using a digital terrain model: Journal of Geology, v. 101, p. 259-278.

Graham, S.E., and Pike, R.J., 1998a, Elevation maps of the San Francisco Bay region, California; a digital database: U.S. Geological Survey Open-File Report 98-625, 17 p., scales 1:275,000 and 1:125,000 [http://pubs.usgs.gov/ of/1998/of98-625/].

Graham, S.E., and Pike, R.J., 1998b, Slope maps of the San Francisco Bay region, California; a digital database: U.S. Geological Survey Open-File Report 98-766, 17 p., scales 1:275,000 and 1:125,000 [http://pubs.usgs.gov/of/1998/ of 98-766/].

Graymer, R.W., 2000, Geologic map and map database of the Oakland metropolitan area, Alameda, Contra Costa, and San Francisco Counties, California: U.S. Geological Survey Miscellaneous Field Studies Map MF-2342, 29 p., scale 1:50,000 [http://pubs.usgs.gov/mf/2000/2342/].

Graymer, R.W., and Godt, J.W., 1999, Map showing locations of damaging landslides in Contra Costa County, California, resulting from 1997-98 El Niño rainstorms: U.S. Geological Survey Miscellaneous Field Studies Map MF-2325-E, scale 1:125,000 [http://pubs.usgs.gov/mf/1999/mf-2325-e/].
Harding, R.C., 1969, Landslides-a continuing problem for Bay Area development, in Danehy, A.E., assisted by Harding, R.C., eds., Urban Environmental Geology in the San Francisco Bay Region: Association of Engineering Geologists, San Francisco Section, Special Publication, p. 65-74.

Haydon, W.D., 1995, Landslide hazards in the MartinezWalnut Creek area, Contra Costa County, California: California Division of Mines and Geology Open-File Report 95-12, scale 1:24,000.

Hilley, G.E., Bürgmann, Roland, Ferretti, Alessandro, Novali, Fabrizio, and Rocca, Fabio, 2004, Dynamics of slowmoving landslides from permanent scatterer analysis: Science, v. 304, no. 5679, p. 1,952-1,955.

Jayko, A.S., Rymer, M.J., Prentice, C.S., Wilson, R.C., and Wells, R.E., 1998, Scenic Drive Landslide of JanuaryMarch 1998, La Honda, San Mateo County, California: U.S. Geological Survey Open-File Report 98-229 [http://pubs. usgs.gov/of/1998/of98-229/].

Keefer, D.K., and Johnson, A.M., 1983, Earth flowsmorphology, mobilization, and movement: U.S. Geological Survey Professional Paper 1264, 56 p.

Keefer, D.K., Griggs, G.B., and Harp, E.L., 1998, Large landslides near the San Andreas fault in the Summit Ridge area, Santa Cruz Mountains, California, in Keefer, D.K., ed., The Loma Prieta, California, Earthquake of October 17, 1989-Landslides: U.S. Geological Survey Professional Paper 1551-C, p. C71-C128 [http://pubs.usgs.gov/pp/ pp1551/pp1551c/].

Newman, E.B., Paradis, A.R., and Brabb, E.E., 1978, Feasibility and cost of using a computer to prepare landslide susceptibility maps of the San Francisco Bay region, California: U.S. Geological Survey Bulletin 1443, 27 p.

Nilsen, T.H., 1973, Preliminary photointerpretation map of landslide and other surficial deposits of the Concord 15-minute quadrangle and the Oakland West, Richmond, and part of the San Quentin 7.5-minute quadrangles, Contra Costa and Alameda Counties, California: U.S. Geological Survey Miscellaneous Field Studies Map MF-493, scale 1:62,500.

Nilsen, T.H., 1975, Preliminary photointerpretation maps of landslide and other surficial deposits of 56 7.5-minute quadrangles, Alameda, Contra Costa, and Santa Clara Counties, California (with parts of adjoining counties on several maps by John A. Bartow, Virgil A. Frizzell, Jr., and John D. Sims): U.S. Geological Survey Open-File Report 75-277, scale 1:24,000.

Nilsen, T.H., and Turner, B.L., 1975, Influence of rainfall and ancient landslide deposits on recent landslides (1950-71) in urban areas of Contra Costa County, California: U.S. Geological Survey Bulletin 1388, 18 p.

Nilsen, T.H., Taylor, F.A., and Brabb, E.E., 1976a, Recent landslides in Alameda County, California (1940-71) — an estimate of economic losses and correlations with slope, rainfall, and ancient landslide deposits: U.S. Geological Survey Bulletin 1398, 21 p., scale 1:62,500.

Nilsen, T.H., Taylor, F.A., and Dean, R.M., 1976b, Natural 
conditions that control landsliding in the San Francisco Bay region - an analysis based on data from the 1968-69 and 1972-73 rainy seasons: U.S. Geological Survey Bulletin 1424, 35 p., scale 1:250,000.

Nilsen, T.H., and Wright, R.H., 1979, Relative slope stability of the San Francisco Bay region, in Nilsen, T.H., Wright, R.H., Vlasic, T.C., and Spangle, W.E., Relative slope stability and land-use planning in the San Francisco Bay region, California: U.S. Geological Survey Professional Paper 944, p. 16-55, scale 1:125,000.

Perkins, J.B., and Chuaqui, Ben, 1996, Existing land use in 1995 - data for Bay Area counties and cities: Oakland, California, Association of Bay Area Governments, 200 p.

Pike, R.J., 1997, Index to detailed maps of landslides in the San Francisco Bay region, California: U.S. Geological Survey Open-File Report 97-745-D, 20 p. [http://pubs.usgs. gov/of/1997/of 97-745/].

Pike, R.J., and Sobieszczyk, Steven, 2002, A digital map of susceptibility to large landslides in Santa Clara County, California [abs.]: EOS, Transactions of the American Geophysical Union, v. 83, no. 47 (Supplement), p. F557, no. H12D-0956.

Pike, R.J., Cannon, S.H., Ellen, S.D., Graham, S.E., and others, 1998, Slope failure and shoreline retreat during northern California's latest El Niño: GSA Today, v. 8, no. 8, p. 1-6.

Pike, R.J., Graymer, R.W., Roberts, Sebastian, Kalman, N.B., and Sobieszczyk, Steven, 2001, Map and map database of susceptibility to slope failure by sliding and earthflow in the Oakland area, California: U.S. Geological Survey Miscellaneous Field Studies Map MF-2385, 37 p., scale 1:50,000 [http://pubs.usgs.gov/mf/2002/2385/].

Pike, R.J., Kalman, N.B., Graymer, R.W., and Roberts, Sebastian, 2000, Tests of a revised model for mapping landslide susceptibility in the San Francisco Bay region [abs.]: EOS, Transactions of the American Geophysical Union, v. 81, no. 48 (Supplement), p. F540.

Radbruch, D.H., 1969, Areal and engineering geology of the Oakland East quadrangle, California: U.S. Geological Survey Geologic Quadrangle Map GQ-769, scale 1:24,000.

Radbruch, D.H., and Crowther, K.C., 1970, Map showing areas of relative amounts of landslides in California: U.S. Geological Survey Open-File Report 70-270, 36 p., 2 sheets, scale 1:500,000.

Radbruch, D.H., and Crowther, K.C., 1973, Map showing areas of estimated relative amounts of landslides in California: U.S. Geological Survey Miscellaneous Geologic Investigations Map I-747, scale 1:1,000,000.

Radbruch, D.H., and Case, J.E., 1967, Preliminary geologic map and engineering geologic information, Oakland and vicinity, California: U.S. Geological Survey Open-File Report 67-183, 2 sheets, scale 1:24,000.

Radbruch, D.H., and Weiler, L.M., 1963, Preliminary report on landslides in a part of the Orinda Formation, Contra Costa County, California: U.S. Geological Survey Open-File Report 63-112, 35 p., scale 1:24,000.

Reneau, S.L., Dietrich, W.E., Dorn, R.I., Berger, C.R., and Rubin, Meyer, 1986, Geomorphic and paleoclimate implications of latest Pleistocene radiocarbon dates from colluvium-mantled hollows, California: Geology, v. 14, no. 8, p. 655-658.

Rogers, J.D., 1998, Mission Peak landslide, Fremont, California [abs.]: EOS, Transactions of the American Geophysical Union, v. 79, no. 45 (Supplement), p. F266, no. H72F-09.

Van Den Eeckhaut, Miet, Vanwalleghem, Tom, Poesen, Jan, Govers, Gerard, Verstraeten, Gert, and Vandekerckhove, Liesbeth, 2006, Prediction of landslide susceptibility using rare events logistic regression: a case-study in the Flemish Ardennes (Belgium): Geomorphology, v. 76, nos. 3-4, p. 392-410.

Varnes, D.J., 1978, Slope movement types and processes, in Schuster, R.L., and Krizek, R.J., eds., Landslides - analysis and control: Washington, D.C., Transportation Research Board, National Research Council, Special Report 176, p. 11-33.

Weaver, C.E., 1953, Eocene and Paleocene deposits at Martinez, California: Seattle, Washington University Publications in Geological Science, v. 7, 102 p.

Wells, R.E., Rymer, M.J., Prentice, C.S., and Wheeler, K.L., 2005, Map showing features and displacements of the Scenic Drive landslide, La Honda, California, during the period March 31-May 7, 2005: U.S. Geological Survey Open-File Report 2005-1191 [http://pubs.usgs.gov/ of/2005/1191/].

Wells, R.E., Rymer, M.J., Prentice, C.S., and Wheeler, K.L., 2006, Map showing features and displacements of the Scenic Drive landslide, La Honda, California, during the period March 31, 2005-November 5, 2006: U.S. Geological Survey Open-File Report 2006-1397 [http://pubs.usgs.gov/ of/2006/1397/].

Wentworth, C.M., Ellen, S.D., and Mark, R.K., 1987, Improved analyses of regional engineering geology using geographic information systems, in GIS-San Francisco, Second International Conference, Exhibits, and Workshops on Geographic Information Systems, October 26-30, 1987, San Francisco [Proceedings]: American Society for Photogrammetry and Remote Sensing/American Congress on Surveying and Mapping, v. 2, p. 636-649.

Wentworth, C.M., Graham, S.E., Pike, R.J., Beukelman, G.S., Ramsey, D.W., and Barron, A.D., 1997, Summary distribution of slides and earth flows in the San Francisco Bay region, California: U.S. Geological Survey Open-File Report 97-745-C, 10 p., 11 sheets [http://pubs.usgs.gov/ of/1997/of97-745/].

Wieczorek, G.F., 1984, Preparing a detailed landslideinventory map for hazard evaluation and reduction: Association of Engineering Geologists Bulletin, v. 21, no. 3, p. 337-342.

Wills, C.J., and McCrink, T.P., 2002, Comparing landslide inventories - the map depends on the method: Environmental and Engineering Geoscience, v. 8, no. 4, p. 279-295. 
Wilson, R.I., Wiegers, M.O., McCrink, T.P., Haydon, W.D., and McMillan, J.R., 2003, Earthquake-induced landslide zones in the Oakland East 7.5-minute quadrangle, Alameda County, California, in Seismic hazard zone report for the
Oakland East 7.5-minute quadrangle, Alameda County, California: California Geological Survey Seismic Hazard Zone Report 080, p. 25-48, plate 2.1 [http://gmw.consrv. ca.gov/shmp/download/evalrpt/oake_eval.pdf]. 
Chapter 3

\title{
Susceptibility to Shallow Landsliding Modeled for the Oakland-Berkeley Area, Northern California
}

\author{
By Kevin M. Schmidt and Steven Sobieszczyk
}

\begin{abstract}
The susceptibility of shallow soil to landsliding by largemagnitude rain storms is estimated for upland hillsides in the Oakland-Berkeley area of northern California, from geographic information system (GIS) analyses of digital elevation models at 5- and 10-m resolution. The regional-scale prediction of source regions for rainfall-induced shallow landslides, which is based on the SHALSTAB model, highlights the topographic influence on initiation sites, which commonly are areas of steep, convergent topography. This broad-scale estimation does not account for such site-specific variability as material properties, vegetation cover, or local hydrologic response; however, on the basis of topographic factors, it does denote the relative spatial density of potential initiation sites, which can mobilize into destructive, fast-moving debris flows.
\end{abstract}

\section{Introduction}

Large storms in the San Francisco Bay region have triggered many shallow landslides (Ellen and others, 1988, 1997). This type of failure, which usually occurs during or shortly after intense storms or periods of prolonged high rainfall, typically affects shallow soil overlying bedrock on steep slopes (Caine, 1980; Cannon, 1988). The initial landslide can mobilize into a destructive mass movement known as a debris flow or "mudslide," a highly mobile, fast-moving (as much as $60 \mathrm{~km} / \mathrm{hr}$ ) slurry of water, soil, rock, vegetation, and other debris (Cruden and Varnes, 1996). Occurring suddenly, debris flows can rapidly move downslope several kilometers from the point of initiation, often incorporating more downstream material and thereby substantially increasing in volume. The maps on plates 2 and 3 are regional-scale portrayals of likely initiation sites for these shallow landslides, often mobilizing into debris flows, that could occur during severe rainstorms in the hills east of San Francisco Bay, northern California (fig. 3-1). This scenario complements others in this report that lead to estimates of landslides in the same area, induced by either precipitation sustained over a longer duration (see Pike and Sobieszczyk, ch. 2, this report) or a major earthquake (see Miles and Keefer, ch. 4, this report).
Debris flows pose significant hazard to life, resources, and property in urban regions during and immediately following heavy rainfall. The January 1982 storm in the San Francisco Bay region, for example, initiated over 18,000 landslides (principally shallow landslides that mobilized into debris flows), which caused 25 fatalities and $\$ 66$ million in property damage (Creasey, 1988): losses in Contra Costa County alone exceeded \$7 million and, in Alameda County, approached \$3.6 million, the majority of the damage being to private property. An earlier example is the winter of 1968-69, for which Fleming and Taylor (1980) estimated that landslide costs in the San Francisco Bay region totaled about $\$ 56$ million. The most recent major debris-flow event in the East Bay hills near the Oakland-Berkeley study area occurred in February 1998 (fig. 3-1; Coe and Godt, 2001; Coe and others, 2004).

Field observations reveal that shallow landslides often initiate at locations in the landscape that are characteristic of where the subsurface flow of water most effectively decreases the gravitational stability of relatively unconsolidated soil or colluvium (weathered rock) overlying bedrock. Subsurfacewater flow governs the spatial extent of saturated areas, which in turn affects the runoff distribution and magnitude of positive pore-water pressures within hillslopes (Dunne and Black,

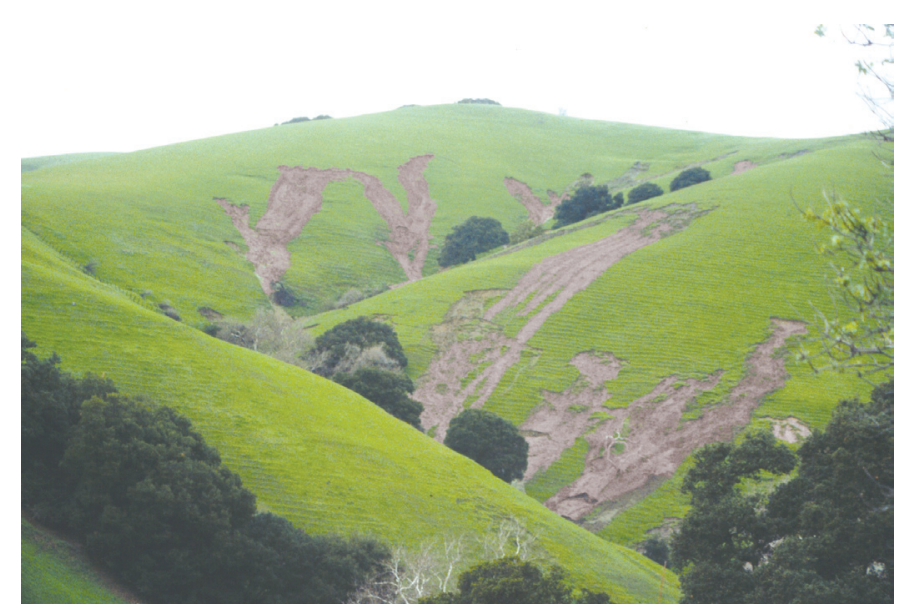

Figure 3-1. Source areas and downslope tracks of multiple debris flows in East Bay hills of Alameda County, triggered by February 1998 storm. Photograph by S.D. Ellen, U.S. Geological Survey. 
1970; Dunne and others, 1975). Hillslope hollows, which are sites of topographic convergence at the upslope tip of channel networks, focus both sediment and subsurface flow and, thus, can be preferential sites of landslide initiation in fluvially dissected landscapes (Hack and Goodlett, 1960; Hack, 1965; Johnson and Rahn, 1970; Campbell, 1975; Reneau and Dietrich, 1987). By combining observations and assumptions on hillslope hydrology and slope stability, it is possible to predict future initiation sites of shallow landsliding from measurements of topographic form. Accordingly, the relative susceptibility to shallow landsliding depicted in the maps on plates 2 and 3 is calculated from geographic information system (GIS) analyses of topography represented by two digital elevation models (DEMs) at different grid spacings. The map on plate 2 representing shallow landslide susceptibility is based on a $10-\mathrm{m}$ DEM; the map on plate 3 is based on a $5-\mathrm{m}$ DEM of a smaller area.

\section{The Theoretical Model}

Implemented using GIS, the SHALSTAB model of slope stability (Dietrich and others, 1993, 1995; Montgomery and Dietrich, 1994) is a steady-state approximation of subsurfaceflow runoff. The model incorporates the topographic influence on subsurface discharge and, hence, the spatial distribution of relative soil saturation and an approximation of infinite-slope stability. Topography influences the location of shallowlandslide initiation through the influence of slope gradient as well as three-dimensional curvature (here, convergence), which acts to concentrate subsurface-water flow. For more detailed discussions of the SHALSTAB model, its assumptions, and its performance, see Dietrich and others (1993, 1995, 2001), Montgomery and Dietrich (1994), Montgomery and others (1998, 2000), and Meisina and Scarabelli (2007).

For this version of the model, we assume that the soil is cohesionless, and we also assume that the internal angle of friction, the bulk density, and the saturated conductivity of the soil are spatially invariant. Assuming the material is cohesionless increases the spatial extent of instability across the landslide-prone portion of the landscape because the stabilizing influence of cohesion from plant roots or clay-rich soils is neglected. The predicted patterns of slope stability are expressed as the ratio $q / T$ :

$$
\frac{q}{T}=\frac{\rho_{s} b \sin \theta}{\rho_{w} A}\left(1-\frac{\tan \theta}{\tan \phi}\right)
$$

where $q$ is the effective precipitation, rainfall minus evapotranspiration, $T$ is the transmissivity of the soil, the rate at which subsurface water moves downslope under a unit hydraulic gradient, ${ }_{s}$ is the bulk density of saturated sediment, $b$ is the unit contour length through which subsurface discharge flows, is the ground-surface slope, ${ }_{w}$ is the bulk density of water, $A$ is the upslope contributing drainage area, and is the internal friction angle of the colluvium. The influence of topographic convergence, concentrating runoff and elevating soil saturation, is captured by the upslope contributing drainage area relative to the contour length through which water flows. If all other factors remain constant, then the larger the precipitation $(q)$ is relative to the soil transmissivity $(T)$, the more likely that the hydrologic response will reach levels capable of inducing instability. Because the actual hydrologic parameters $q$ and $T$ are largely unconstrained by field measurements and are likely to vary considerably in both time and space, we solve for the ratio $q / T$. All simulations are based on the same input parameters of a cohesionless soil, using values of $=40^{\circ}, s=1,700 \mathrm{~kg} / \mathrm{m}^{3}$, and $w^{2}=1,000 \mathrm{~kg} / \mathrm{m}^{3}$. The $40^{\circ}$ value chosen for is representative of a dense, well-graded sand or sand-andgravel mixture, typical of many soils derived from sedimentary bedrock in the study area (Ellen and Wentworth, 1995).

Although the bedrock units vary widely across the region (Graymer, 2000) and material properties vary between geologic units (Ellen and Wentworth, 1995), we assume uniform soil properties for the entire study area, for simplicity and to highlight the influence of topographic form on shallow-soil slope stability. In characterizing the material strength as cohesionless and setting such a relatively high friction angle, we do not intend to represent the actual properties of hillslope materials. For two reasons the material properties of the soil are represented by friction angle alone rather than by a combination of friction angle and cohesion. First, if the cohesion term is introduced into the infinite-slope-based model, it must be accompanied by an estimate of soil depth; because the distribution of soil depth throughout the study area is poorly known, we must adopt arbitrary soil thicknesses. Second, cohesion is a function of both the soil itself and the nature of the local vegetation; lacking estimates of vegetation type, density, and relative health, it is difficult to obtain a meaningful cohesion value for a regional-scale predictive model of landslide-initiation sites for a broad variety of vegetation cover and soil types. By assuming a relatively high friction angle ( ) value, the model self-selects those sites that are most prone to generating shallow landslides on steep slopes. Thus, we are not modeling the rainfall-induced landslides described as earth flows (Keefer and Johnson, 1983; Cruden and Varnes, 1996) or deeper seated rock slides (Cruden and Varnes, 1996), which tend to occur on more moderate slopes in response to more sustained precipitation (see discussion in chs. 1 and 2, this report).

\section{Map Units}

The maps on plates 2 and 3 show the distribution of an index number, $\log (q / T)$, that reflects the relative susceptibility to the initiation of shallow landslides. The ratio of hydrologic variables $q$ / $T$ captures the magnitude of the precipitation event $(q)$ relative to the subsurface ability to convey the water downslope, the transmissivity $(T)$. The 
map units are expressed as $\log (q / T)$ because $q / T$ always is a small number. The quantity $\log (q / T)$ is mapped in increments of 0.3 units, equivalent to a factor of two variation in the ratio $q / T$. Larger negative values of $\log (q / T)$ reflect smaller values of $q / T$. As $q$ increases relative to $T$, the soil is more likely to be highly saturated, whereupon more sites are likely to become unstable. For example, if transmissivity is constant, smaller values of $q$ / $T$ represent lower steadystate rainfall intensities. Hence, parts of the landscape represented by $\operatorname{larger}-\log (q / T)$ values will likely generate shallow slides under lower rainfall intensities and, thus, have higher landslide susceptibilities.

Sites of chronic instability, which are predicted to be unstable even in unsaturated conditions, regardless of rainfall, are shown in purple on the maps on plates 2 and 3. These are areas where $>\tan$, and consequently the ground is prone to failure without any added destabilization by rainwater; they are likely to be steep exposures of bedrock or very thin soils. Areas mapped as high susceptibility to shallow landsliding are those where, in theory, either low total rainfall or low rainfall intensity is sufficient to destabilize a slope; represented on the maps by warm colors (red and magenta), these areas of large $-\log (q / T)$ values designate areas where small and, typically, frequent storms could produce landslides. More stable areas, which require intense rainfall to trigger landsliding and are mapped as low susceptibility, are shown by cool colors (green and yellow) on the maps. Slopes that are stable under saturated conditions and that do not require cohesive reinforcement from plant cover or clay soil are shown in light gray on the maps. The patterns of critical rainfall (in other words, precipitation sufficient to induce shallow landsliding) correlate with strongly convergent topography on steep gradients just downslope of ridge crests. Other physiographic settings are less prone to instability.

\section{The Digital Elevation Models}

Landslide susceptibility of shallow soils was modeled separately from two digital elevation models (DEMs) that differ in grid spacing (10 $\mathrm{m}$ and $5 \mathrm{~m}$ ). The $10-\mathrm{m}$ DEM was compiled by the U.S. Geological Survey from 7.5 ' quadrangle digital line graphs (DLGs), hypsographic data, and (or) by photogrammetric methods. The data are a regular array of elevations referenced horizontally on a Universal Transverse Mercator (UTM) coordinate system (NAD27); all the source DEMs, DLGs, digital raster graphics (DRGs), and digital orthophoto quadrangles (DOQs) are from the U.S. Geological Survey (available from http://bard.wr.usgs.gov/). The 10-m data were used to evaluate slope stability across the entire seven-quadrangle study area (pl. 2).

From DOQs, the Oakland Office of Communication and Information Systems and the California Geological Survey (CGS) prepared a 5-m DEM (T. McCrink, CGS, unpub. data, 1999); source stereo-pair aerial photography for the DOQs was collected at a scale of 1:6,000 by Pacific Aerial Surveys of Oakland, August 6-20, 1994 (for additional information on the genesis and further use of topographic data for seismic hazard evaluation, see Wilson and others, 2003). The original principal coordinates for the 5-m DEM were in the California Plane System (Zone 3), which is based on the North American Datum of 1983 (NAD83) and the Vertical Datum of 1987 (NAVD87); for this study, we reprojected the 5-m DEM into UTM coordinates, which are based on the North American Datum of 1927 (NAD27). The vertical accuracy is estimated to be on the order of 1 to $2 \mathrm{~m}$. Because the 5-m data covered only the cities of Oakland and Piedmont, the derivative analysis of slope stability was restricted to those areas (pl. 3).

The DEMs contain erroneous artifacts, only the most noticeable of which we encountered during the $\log (q / T)$ analysis of the 5-m data for the map on plate 3 . A shadedrelief image (not shown in this report) generated from the $5-\mathrm{m}$ DEM revealed north-south- and east-west-trending irregularities that are spaced at roughly $175 \mathrm{~m}$; however, although these defects may reduce the aesthetics of the map, we believe they have only a minor influence on the number of cells in a given stability category and, thus, the overall pattern of predicted susceptibility.

\section{Discussion of the Susceptibility Map}

The terrain-based approach applied here is one of many by which landslide susceptibility may be assessed regionally. Other widely used techniques include field inspection, landslide-inventory interpretation, multivariate statistical analyses of essential factors controlling stability, and probabilistic simulations. Although each of these may be valid, no single approach can predict unequivocally the exact location and timing of future landsliding. Relative slope stability over a hillslope is a complex function of topography, material properties, and hydrology; factors include colluvium thickness, hydraulic conductivity, subsurface-flow orientation, and the presence of macropores or bedrock-fracture flow, as well as the material strength that arises from both the internal friction angle of the colluvium and the cohesion attributable to soil and root reinforcement. Spatial and temporal differences in many of the variables preclude accurate site predictions without additional detailed information. The maps presented here (pls. 2 and 3) simplify many of these relations and so are of regional value only; they cannot replace site-specific evaluations by a qualified geotechnical engineer or geologist.

Because hydrologic response of the model is driven largely by slope convergence and gradient, instability generally concentrates in areas of topographic concavity on steep hillsides. Accordingly, patterns of predicted landslide susceptibility on the maps mimic the spatial distribution of steep, convergent terrain. Although some shallow landslides initiate on steep planar hillslopes or in regions modified by human activities, modification of topography or hydrologic flow paths was not considered in this analysis. Hydrologic response on 
actual hillslopes depends on the distribution and thickness of soil, the variability of hydraulic conductivity within and between the surface materials and underlying bedrock, and the presence and magnitude of bedrock-fracture flow.

Patterns of temporally variable rainfall also influence the location of landsliding. During short, intense rainstorms, for example, Wieczorek (1987) observed relatively thin landslides on steep, planar hillslopes. Because the model as presented here does not account for soil thickness or time-variant rainfall, the actual pattern of shallow landsliding probably will reflect the local character of the rainstorm. Additionally, the maps on plates 2 and 3 depict only the landslide-initiation location and not the volume of material mobilized, the potential for downslope runout (fig. 3-1), or the distance traveled.

Relative landslide susceptibility modeled from the 5- and 10-m DEMs differs systematically over the same area. The 5-m DEM (neglecting data artifacts) is apt to more accurately portray steep, convergent, shallow-landslide-prone topography, as evidenced by the higher mean and maximum gradients for the 5-m data. Unlike the 10-m data, the 5-m DEM also more accurately reflects human modifications to the landscape because of its higher resolution, as well as the fact that it postdates much of the post-WW II cut-and-fill grading in this area. For example, the level of detail of the 5-m DEM shows such urban features as embankments along freeways and surrounding the McAfee Coliseum in Oakland, areas that are not immune to shallow failure. In addition, mean and maximum ratios of upslope drainage area to contour length $(A / b)$ for the 5-m DEM are smaller, reflecting a higher degree of landscape dissection not captured by the somewhat coarser 10-m DEM. These influences are revealed in the distribution of $\log (q / T)$ categories such that the map on plate 3 shows more chronically unstable areas.

Finally, regional-scale investigations elsewhere in the San Francisco Bay region (San Mateo County) after the January 3-5, 1982, storm revealed that underlying bedrock exerted a strong influence on landslide occurrence (Wieczorek and others, 1988). Debris-flow incidence varied widely but approached 11 failures per square kilometer for the most susceptible geologic unit in the county. In the Oakland-Berkeley Hills, we find a similarly clear correlation between bedrock lithology (Graymer, 2000) and observed locations of shallow landslides that occurred in 1982 (Wieczorek, 1987; Ellen and others, 1997). These locations are not shown on the maps on plates 2 or 3; because the 1982 landslides were compiled for a broad-scale synthesis (Ellen and others, 1997), their comparatively coarse georeferencing renders them incompatible with site-specific analyses at the finer scale of the susceptibility maps on plates 2 and 3. For other correlations between rock type and landsliding in the study area, see Pike and Sobieszczyk (ch. 2, this report) and Miles and Keefer (ch. 4, this report). Research into the spatial density of shallow landslides with respect to the underlying bedrock type, as well as the influence of colluvium depth on the predicted patterns of potential instability, is ongoing.

\section{References Cited}

Caine, N., 1980, The rainfall intensity-duration control on shallow landslides and debris flows: Geografiska Annaler, v. 62A, p. 23-27.

Campbell, R.H., 1975, Soil slips, debris flows and rainstorms in the Santa Monica Mountains and vicinity, southern California: U.S. Geological Survey Professional Paper 851, $51 \mathrm{p}$.

Cannon, S.H., 1988, Regional rainfall-threshold conditions for abundant debris-flow activity, in Ellen, S.D., and Wieczorek, G.F., eds., Landslides, floods, and marine effects of the storm of January 3-5, 1982, in the San Francisco Bay region, California: U.S. Geological Survey Professional Paper 1434, p. 35-42 [http://pubs.usgs.gov/pp/1988/1434/].

Coe, J.A., and Godt, J.W., 2001, Debris flows triggered by the El Niño rainstorm of February 2-3, 1998, Walpert Ridge and vicinity, Alameda County, California: U.S. Geological Survey Miscellaneous Field Studies Map MF-2384, scale 1:24,000 [http://pubs.usgs.gov/mf/2002/mf-2384/].

Coe, J.A., Godt, J.W., and Tachker, Pierre, 2004, Map showing recent (1997-98 El Niño) and historical landslides, Crow Creek and vicinity, Alameda and Contra Costa Counties, California: U.S. Geological Survey Scientific Investigations Map 2859, scale 1:18,000 [http://pubs.usgs. gov/sim/2004/2859/].

Creasey, C.L., 1988, Landslide damage - a costly outcome of the storm, in Ellen, S.D., and Wieczorek, G.F., eds., Landslides, floods, and marine effects of the storm of January 3-5, 1982, in the San Francisco Bay region, California: U.S. Geological Survey Professional Paper 1434, p. 195-203 [http://pubs.usgs.gov/pp/1988/1434/].

Cruden, D.M., and Varnes, D.J., 1996, Landslide types and processes, in Turner, A.K., and Schuster, R.L., eds., Landslides investigation and mitigation: Washington, D.C., Transportation Research Board, National Research Council, Special Report 247, p. 36-75.

Dietrich, W.E., Bellugi, D., and Real de Asua, R., 2001, Validation of the shallow landslide model, SHALSTAB, for forest management, in Wigmosta, M.S., and Burges, S.J., eds., Land use and watersheds - human influence on hydrology and geomorphology in urban and forest areas: Washington, D.C., American Geophysical Union, Water Science and Application 2, p. 195-227.

Dietrich, W.E., Reiss, R., Hsu, M.-L., and Montgomery, D.R., 1995, A process-based model for colluvial soil depth and shallow landsliding using digital elevation data: Hydrological Processes, v. 9, p. 383-400.

Dietrich, W.E., Wilson, C.J., Montgomery, D.R., and McKean, J., 1993, Analysis of erosion thresholds, channel networks, and landscape morphology using a digital terrain model: Journal of Geology, v. 101, p. 259-278.

Dunne, T., and Black, R.G., 1970, An experimental investigation of runoff production in permeable soils: Water Resources Research, v. 6(2), p. 478-490. 
Dunne, T., Moore, T.R., and Taylor, C.H., 1975, Recognition and prediction of runoff-producing zones in humid regions: Hydrological Sciences Bulletin, v. 20, p. 305-327.

Ellen, S.D., and Wentworth, C.M., 1995, Hillside materials and slopes of the San Francisco Bay region: U.S. Geological Survey Professional Paper 1357, 215 p.

Ellen, S.D., Mark, R.K., Wieczorek, G.F., Wentworth, C.M., Ramsey, D.W., and May, T.E., 1997, Map showing principal debris-flow source areas in the San Francisco Bay region, California: U.S. Geological Survey Open-File Report 97-745-E [http://pubs.usgs.gov/of/1997/of97-745/].

Ellen, S.D., Wieczorek, G.F., Brown, W.M., and Herd, D.G., 1988, Introduction, in Ellen, S.D., and Wieczorek, G.F., eds., Landslides, floods, and marine effects of the storm of January 3-5, 1982, in the San Francisco Bay region, California: U.S. Geological Survey Professional Paper 1434, p. 1-5 [http://pubs.usgs.gov/pp/1988/1434/].

Fleming, R.W., and Taylor, F.A., 1980, Estimating the cost of landslide damage in the United States: U.S. Geological Survey Circular 832, $21 \mathrm{p}$.

Graymer, R.W., 2000, Geologic map and map database of the Oakland metropolitan area, Alameda, Contra Costa, and San Francisco Counties, California: U.S. Geological Survey Miscellaneous Field Studies Map MF-2342, 29 p., scale 1:50,000 [http://pubs.usgs.gov/mf/2000/2342/].

Hack, J.T., 1965, Geomorphology of the Shenandoah Valley, Virginia and West Virginia, and origin of the residual ore deposits: U.S. Geological Survey Professional Paper 484, $84 \mathrm{p}$.

Hack, J.T., and Goodlett, J.C., 1960, Geomorphology of forest ecology of a mountain region in the central Appalachians: U.S. Geological Survey Professional Paper 347, 66 p.

Johnson, A.M., and Rahn, P.H., 1970, Mobilization of debris flows: Zeitschrift für Geomorphologie Supplement, v. 9, p. 168-186.

Keefer, D.K., and Johnson, A.M., 1983, Earth flows; morphology, mobilization, and movement: U.S. Geological Survey Professional Paper 1264, 56 p.

Meisina, Claudia, and Scarabelli, S., 2007, A comparative analysis of terrain stability models for predicting shallow landslides in colluvial soils: Geomorphology, v. 87, no. 3, p.
207-223.

Montgomery, D.R., and Dietrich, W.E., 1994, A physically based model for the topographic control on shallow landsliding: Water Resources Research, v. 30, p. 1,153-1,171.

Montgomery, D.R., Schmidt, K.M., Greenberg, H.M., and Dietrich, W.E., 2000, Forest clearing and regional landsliding: Geology, v. 28, p. 311-314.

Montgomery, D.R., Sullivan, K., and Greenberg, H.M., 1998, Regional test of a model for shallow landsliding: Hydrological Processes, v. 12, p. 943-955.

Reneau, S.L., and Dietrich, W.E., 1987, Size and location of colluvial landslides in a steep forested landscape, in Beschta, R.L., Blinn, T., Grant, G.E., Ice, G.G., and Swanson, F.J., eds., Erosion and sedimentation in the Pacific Rim: International Association of Hydrological Sciences Publication 165, p. 39-48.

Wieczorek, G.F., 1987, Effect of rainfall intensity and duration on debris flows in central Santa Cruz Mountains, California, in Costa, J.E., and Wieczorek, G.F., eds., Debris flows/avalanches - process, recognition, and mitigation: Geological Society of America Reviews in Engineering Geology, Volume VII, p. 93-104.

Wieczorek, G.F., Harp, E.L., Mark, R.K., and Bhattacharyya, A.K., 1988, Debris flows and other landslides in San Mateo, Santa Cruz, Contra Costa, Alameda, Napa, Solano, Sonoma, Lake, and Yolo Counties, and factors influencing debris-flow distribution, in Ellen, S.D., and Wieczorek, G.F., eds., Landslides, floods, and marine effects of the storm of January 3-5, 1982, in the San Francisco Bay region, California: U.S. Geological Survey Professional Paper 1434, p. 133-161 [http://pubs.usgs.gov/ pp/1988/1434/].

Wilson, R.I., Wiegers, M.O., McCrink, T.P., Haydon, W.D., and McMillan, J.R., 2003, Earthquake-induced landslide zones in the Oakland East 7.5-minute quadrangle, Alameda County, California, in Seismic hazard zone report for the Oakland East 7.5-minute quadrangle, Alameda County, California: California Geological Survey Seismic Hazard Zone Report 080, section 2, p. 25-48 [http://gmw.consrv. ca.gov/shmp/download/evalrpt/oake_eval.pdf]. 
This page intentionally left blank 


\title{
Chapter 4
}

\section{Landslide Hazard Modeled for the Cities of Oakland, Piedmont, and Berkeley, Northern California, from a $M=7.1$ Scenario Earthquake on the Hayward Fault Zone}

\author{
By Scott B. Miles and David K. Keefer
}

\begin{abstract}
The relative hazard from landsliding triggered by a large earthquake along the Hayward Fault Zone is estimated for hillsides in the Oakland-Piedmont-Berkeley area by combining seismic, subsurface-moisture, and slope conditions that favor ground failure. The resulting map of landslide potential, created from a physical model that treats a landslide as a rigid block on an inclined plane (Newmark analysis), was produced in a geographic information system (GIS) from analyses of digital elevation models, geology, and a model of seismic shaking. Landslide potential increases with proximity to the fault and with geologic characteristics favorable to failure.
\end{abstract}

\section{Introduction}

Human casualties and economic losses from landsliding are serious collateral effects of earthquakes (Keefer, 1984), as well as of heavy or persistent rainfall (see chs. 1 through 3, this report). In the 1994 Northridge earthquake (M=6.7), for example, some 11,000 landslides in the greater Los Angeles area blocked roads, severed pipelines, damaged houses, and generated dense dust clouds that triggered an epidemic of Valley Fever (Harp and Jibson, 1995). Long a hazard in the San Francisco Bay region (Youd and Hoose, 1978), landslides mobilized by the 1989 Loma Prieta earthquake $(\mathbf{M}=6.9)$ reactivated portions of older failures (fig. 4-1), damaged at least 200 residences (mostly in the Santa Cruz Mountains), caused some $\$ 30$ million in damage, and blocked highways in the epicentral area for several weeks (Keefer, 1998).

Because an earthquake occurs with little or no warning, the date and time of its resulting landslides cannot be anticipated; only their probable locations can be estimated with reasonable confidence. Gauging the spatial extent of such landsliding is complicated by the coupling of two fundamentally different processes, seismically induced shaking and slope failure (Miles and Keefer, 2000). Wilson and Keefer (1985) and Wieczorek and others (1985) developed approaches to assessing and then mapping seismically induced landslides. On the basis of the 1994 Northridge event, Jibson and others (1998) refined a technique of mapping susceptibility that reflects a variety of landslide scenarios in postulated future earthquakes of different magnitudes. This chapter presents a map of the OaklandPiedmont-Berkeley area (pl. 4) showing the relative degree of hazard predicted from one possible scenario modeled by the technique of Jibson and others (1998).

\section{Overview of the Map}

The map on plate 4 , which combines two previously published maps (Miles and Keefer, 2001a,b), is one of many possible depictions of the hazard from earthquake-triggered

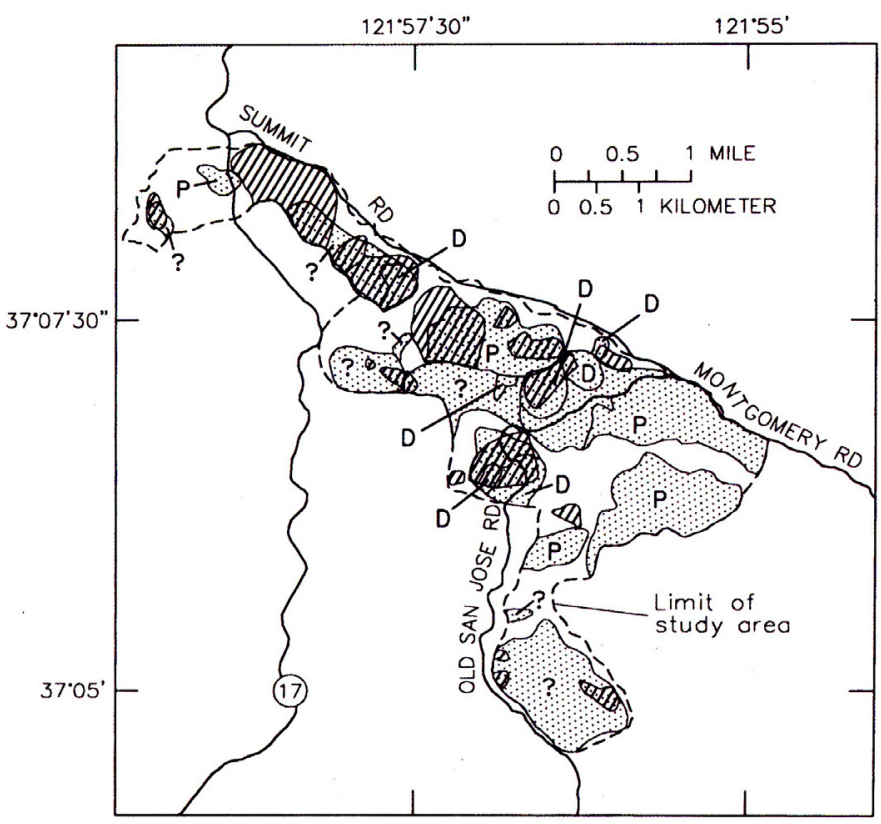

Figure 4-1. Map showing 17 large landslides (diagonal-lined areas) in Summit Road area of Santa Cruz Mountains, triggered by October 1989 Loma Prieta earthquake. Dotted areas are generalized landslide deposits ( $D$, definite; $P$, probable; ?, questionable) identified on pre-earthquake landslide-hazard map (Cooper-Clark and Associates, 1975). From Keefer and others, 1988, fig. 4. 
landsliding that could be modeled from data available for the northern California cities of Berkeley, Oakland, and Piedmont. The simulation depicted by this map reflects a worst-case, or high-hazard, scenario that reflects combined seismic and site conditions consistent with earthquake-induced ground failure: the modeled $\mathbf{M}=7.1$ earthquake assumes the complete rupture of both the northern and southern segments of the Hayward Fault Zone, as well as a ground-water state of total saturation that might result from a major rainstorm or series of storms (see chs. 1 and 2, this report). Under drier conditions the overall hazard will be less, although its spatial patterns are unlikely to differ (for a comparison of the effects of dry and saturated soil conditions, see Miles and Keefer, 2000).

The most common types of landslides that can be expected from the modeled scenario depicted on the map on plate 4 include rock falls, rock slides, and disrupted soil slides (Keefer, 1984). Deeper seated and more coherent (rock) slumps and debris and block slides, which are among the types of landslides modeled in chapter 2 (this report), are to be anticipated as well (see also, Keefer, 1998, p. 2, 11). Portions of some of the existing deep-seated landslides that lie close to the fault zone may remobilize in a large earthquake (Cole and others, 1998; Keefer and others, 1998). The debris flows described in chapters 1 and 3 (this report) by definition are not normally a product of seismic ground motion, but they conceivably could be triggered by an earthquake in saturated soil or during a rainstorm.

The map (pl. 4) was created from the engineering model of Jibson and others (1998), which treats a potential landslide as a rigid block resting on an inclined plane, following the model of Newmark (1965). The model requires various input parameters characterizing the susceptibility to landsliding and the intensity of earthquake ground motion, such as earthquake magnitude, distance to fault, strength of geologic materials, ground-water conditions, and hillside steepness (derived from digital elevation models, or DEMs). Terrain that slopes less than $5^{\circ}$ was excluded from the map on plate 4 because of the negligible potential for most types of failure (Keefer, 1984). Such terrain, however, may be susceptible to liquefaction and, thus, lateral spreading (Bartlett and Youd, 1995). A more complete evaluation for the potential for earthquake-induced ground deformation may be obtained by using this map in combination with maps of the liquefaction hazard (California Geological Survey, 2003a,b,c,d,e; see also, http://geomaps.wr.usgs.gov/sfgeo/ liquefaction/susceptibility.html).

The six levels of hazard depicted on the map (pl. 4) are approximate only. For example, most large areas of highest hazard correlate with relatively weak bedrock east of the Hayward Fault Zone, most notably the Orinda and Moraga Formations, but some areas of moderate to very high hazard also exist west of the fault zone, particularly in older alluvial-fan drainage channels (Graymer and others, 1996). On steep hillsides, however, or in immediate proximity to the Hayward Fault Zone, landslides also are possible in zones of low hazard, owing to mechanisms not modeled by the approach described here. For the purposes of interpretation, therefore, it may be helpful to view the modeled hazard in terms of landslide concentration (for example, the likely number of landslides per square kilometer). Thus, some dense concentrations of landslides may be expected in areas of very high hazard, whereas low hazard areas should contain only a few isolated landslides. Although the likelihood of slope failure increases at the higher levels of hazard shown on the map, the actual area of landsliding in each mapped level will be only a small to moderate percentage of the total area at that level.

When interpreting any hazard map, it is important to consider the limitations and uncertainties of the underlying model. The Newmark (1965) model, which uses the sliding-block analogy to analyze man-made dams and embankments, does not consider such natural mechanisms of ground failure as soil and rock fall, sliding of disrupted soil and rock, or liquefactioninduced landsliding (see Keefer, 1984, for more information on types of landslides caused by earthquakes). The models from which the map (pl. 4) was created were selected from a number of viable and commonly applied alternatives. Constructing the map from other models could lead to different results but, at the same time, show a similar pattern of hazard. Uncertainty associated with the model parameters varies with the particular parameter and with the spatial resolution of the input data (for example, a DEM cell size considerably larger than $10 \mathrm{~m}$ ). Owing to the paucity of earthquake records for the Hayward Fault Zone (for example, the October 21, 1868, event; see http://earthquake.usgs.gov/regional/nca/1868/index.php), the greatest uncertainty affecting the map on plate 4 likely is the expected intensity of earthquake shaking. Although the relative strengths of the geologic units are more certain, the absolute strength within a particular unit is highly variable and adds considerable local uncertainty.

Like its complementary maps developed in chapters 2 and 3 for landslides caused by other processes (pls. 1 through 3 , this report), the map on plate 4 is intended as a tool for regional planning only. This map is not a substitute for the State of California Seismic Hazard Zones maps that delimit potential landsliding and liquefaction for the same area (California Geological Survey, 2003a,b,c,d,e; Wilson and others, 2003). In addition, the map on plate 4 must not be used to determine the absolute risk from seismically triggered landslides at any locality, nor to serve as the sole justification for zoning or rezoning any land parcel, nor to guide detailed design of any utility or transportation lifeline, nor to plan site-specific hazard reduction, nor to set or modify insurance rates. Local site-specific analyses, such as those conducted for homebuilding, should always involve a qualified, licensed engineering geologist or geotechnical engineer.

\section{Technical Explanation}

\section{Analysis of Seismic Slope Performance}

Newmark (1965) noted that the transient motions of an earthquake might lead to deformation of a hillslope before its 
complete failure. The Newmark analysis models a potential landslide, which has a known critical acceleration, as a rigid friction block resting on an inclined plane; it calculates the cumulative displacement of the block as it is subjected to the accelerations of a given earthquake time history by doubleintegrating those parts of the time history that exceed the critical acceleration (Wilson and Keefer, 1983). Thus, conducting a conventional Newmark analysis for a specific slope first requires the selection of the appropriate earthquake record and the determination of the critical acceleration of the slope. Critical acceleration $\left(a_{c}\right)$ can be calculated from the equation developed by Newmark (1965) for the case of planar slip:

$$
a_{c}=(F S-1) \sin \alpha
$$

where $F S$ is the static factor of safety for the slope (see equation 3), and is the thrust angle of the landslide block (typically approximated by the angle of ground slope, or gradient).

The Newmark displacement $\left(D_{N}\right)$, which is generated by the Newmark analysis, is defined as the distance that a hillslope is estimated to move in the modeled earthquake; it is a useful index of how a slope is likely to perform during seismic shaking. To avoid the computational complexity and difficulties of selecting an appropriate earthquake time history associated with a conventional Newmark analysis, several simplified models for estimating Newmark displacements $\left(D_{N}\right)$ have been developed. One of the most popular models (Jibson, 1993) is based on Arias intensity $\left(I_{a}\right)$, rather than peak ground acceleration, because $I_{a}$ more realistically characterizes the damaging effects of ground motion (see, for example, Wilson, 1993). The Arias intensity is a single measure of shaking intensity of the strong-motion record that is calculated by integrating the squared acceleration values. The regression equation was calibrated by double-integrating 11 acceleration time histories, including 10 from California, that have Arias intensities of less than $10 \mathrm{~m} / \mathrm{s}$ over a range of critical acceleration $\left(a_{c}\right)$ values $(0.02-0.40 \mathrm{~g})$. The relation for Newmark displacement $\left(D_{N}\right)$ was later updated using 555 records from 13 earthquakes (Jibson and others, 1998); the current (2008) equation is

$$
\log D_{N}=1.521 \log I_{a}-1.993 \log a_{c}-1.546
$$

where $a_{c}$ is the critical acceleration (see equation 1), and $I_{a}$ is the Arias intensity (see equation 4).

\section{Mapping Newmark Analysis}

A Newmark analysis can be implemented areally across a region by using a geographic information system (GIS). The procedure is summarized by the flow diagram in figure 4-2, in which each labeled box except "Earthquake Magnitude" represents a map or array of $X-Y$ grid cells. A spatial Newmark analysis requires creation of a critical-acceleration map, which is done by applying equation 1 to each map pixel, or grid cell. The thrust angle for each pixel is approximated by a slope gradient calculated from a DEM (here, at a 10-m grid spacing). The static factor of safety (FS) for a spatial analysis most commonly is calculated by applying the infinite-slope model to each pixel; accordingly, the factor of safety of a hillside slope can be expressed as

$$
F S=\frac{c^{\prime}}{\gamma d \sin \alpha}+\frac{\tan \phi^{\prime}}{\tan \alpha}-\frac{m \gamma_{w} \tan \phi^{\prime}}{\gamma \tan \alpha}
$$

where $c$ ' is the effective cohesion, ' is the effective angle of internal friction, $\gamma$ is the material unit weight, $\gamma_{w}$ is the unit weight of water, is the angle of the slope from the horizontal, $d$ is the depth to the failure surface (normal to that surface), and $m$ is the ratio of the height of the water table above the failure surface to total depth $d$. To apply the infinite slope model in a GIS, a map of each parameter is required; alternatively, a particular parameter can be assumed to remain constant throughout the analysis area.

A GIS-based Newmark analysis (fig. 4-2) requires regional characterization of the expected ground motions generated by an earthquake. The descriptor of ground motion varies with the specific Newmark model: for the simplified model of Jibson and others (1998) in equation 2, the required descriptor is the Arias intensity. Expected mean Arias intensity ( $I a$ ) can be estimated from the relation of Wilson (1993):

$$
I_{a}=M-2 \log \sqrt{R^{2}+h^{2}}-4
$$

where $M$ is the moment magnitude, $R$ is the minimum horizontal distance (in kilometers) to the vertical projection of the fault rupture surface, and $h$ is a depth correction factor that in this case defaults to $7.5 \mathrm{~km}$. The final step is to calculate a map of Newmark displacement that is derived from the maps of critical acceleration and earthquake ground motion. Although it is most convenient to use a simplified Newmark model such as that of Jibson and others (1998) to perform this step within a GIS, the conventional Newmark analysis can be implemented by the C-language routine NMGRID, written specifically for this purpose (Miles and Ho, 1999; Miles and Keefer, 2000).

Calculated Newmark displacement likely will differ for any given locality depending on the particular Newmark model (and, thus, the earthquake ground-motion model) employed. Hazard maps created by four different GISimplemented Newmark models were compared by Miles and Keefer (2000). Because of the multiplicity of Newmark-based models and their varied output, we suggest that the results of several models be considered within any decisionmaking or planning context. We also suggest that anyone wishing to incorporate earthquake-induced landslide hazard in such a context should refer to Miles and Keefer (2000) and Miles and others (2000). 


\section{Constructing the Seismic Landslide-Hazard Map}

We created the map on plate 4 from equation 2 , the simplified Newmark model of Jibson and others (1998), and equation 4, the Arias intensity relation of Wilson (1993), following the general procedure outlined in figure 4-2 for a GIS-based Newmark analysis. The map represents a potential high-hazard scenario, an $\mathbf{M}=7.1$ earthquake, which assumes complete rupture of the southern and northern segments of the Hayward Fault Zone and ground-water conditions of complete saturation. The data required for calculating the static factor of safety and critical acceleration are hillslope gradient and several geotechnical properties (equations 1 and 3). We calculated local slope gradients from a grid of elevations assembled from 10-m U.S. Geological Survey DEMs that had been derived from contour lines of 7.5' (1:24,000-scale) quadrangle maps. The steepest slopes calculated in the OaklandPiedmont-Berkeley study area at the $10-\mathrm{m}$ spatial resolution are about $75^{\circ}$ from horizontal.

We assigned regional geotechnical properties to the materials of geologic units shown on the 1:24,000-scale geologic map of Graymer and others (1996). The unit weight of soil or rock was assumed to be a constant $20 \mathrm{kN} / \mathrm{m}^{3}$. The two shear-strength properties, effective friction angle and effective cohesion, were characterized by a three-step process. We gave each geologic unit on the Graymer and others (1996) map one of four relative ratings - poor, fair, varies, and good - that are based on the general slope-stability assessments by Radbruch (1969) for eight units within the Oakland East 7.5' quadrangle. To the geologic units that have ratings of poor and good - the weakest and strongest, respectively - we assigned frictionangle and cohesion values on the basis of minimum and maximum shear-strength values from a database compiled by the California Geological Survey (for example, Miles and Keefer, 2001a,b; Wilson and others, 2003, tables 2.1, 2.2). Units that have the two intermediate ratings of varies and fair were given proportionate values. We then calculated a map of the static factor of safety value for completely dry soil conditions ( $m=0$, equation 3 ) to determine if any pixels had a factor of safety value less than 1.0. To apply equation 3 , we assumed a constant slope-failure depth of $3.33 \mathrm{~m}$, a representative value (Keefer, 1984). Following the procedure of Jibson and others (1998), we uniformly increased the cohesion value for all geologic units until the static factor of safety value for all pixels within the analyzed area exceeded 1.0 (for dry conditions). The final parameters for the four ratings used in calculating the map of static factor of safety for saturated conditions $(m=$ 1 , equation 3 ) are given in table 4-1 (total shear strength, $\tau$, of the materials is included for comparison).

The next step, estimating Arias intensity from the relation of Wilson (1993), requires the following three parameters (equation 4): moment magnitude, horizontal distance to the vertical projection of the fault plane, and a depth-correction factor. We chose a moment magnitude of 7.1 for this scenario because it represents an earthquake that can be expected to generate a significant (if comparatively rare) hazardous event: complete rupture on the northern and southern segments of the Hayward Fault Zone, with an estimated return period of 523 years (Working Group on California Earthquake Probabilities, 1999). The chosen depth-correction factor of $10 \mathrm{~km}$ provides reasonable estimates of Arias intensities and is consistent with previous application of Wilson (1993) and other, similar, models (Miles and Ho, 1999; Miles and Keefer, 2000). Source-to-site distances were calculated from a trace of the Hayward Fault Zone digitized from 1:24,000-scale geologic maps. Calculated Arias intensities range from 6 to $13 \mathrm{~m} / \mathrm{s}$; the high mean value of $11.5 \mathrm{~m} / \mathrm{s}$ reflects the close proximity of the cities of Oakland, Piedmont, and Berkeley to the Hayward Fault Zone.

We calculated the Newmark displacements from equation 2 on the basis of digital maps (not shown) of Arias intensity and critical acceleration. Hillsides that slope less than $5^{\circ}$ were excluded from analysis because the hazard from failure modes other than lateral spreading is negligible (Keefer, 1984). The

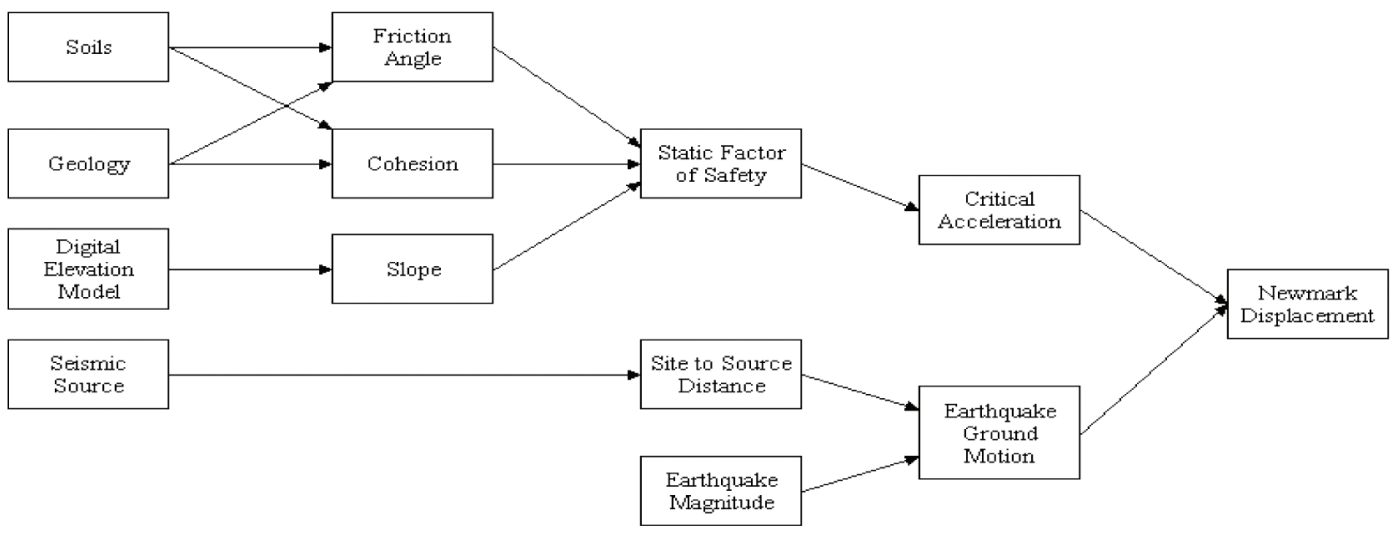

Figure 4-2. General procedure for implementing a spatial Newmark analysis (Jibson and others, 1998). 
Table 4-1. Values of geotechnical properties assigned to four groups of geologic units for calculating the static factor of safety.

\begin{tabular}{c|c|c|c|c}
\hline \hline${ }^{1}$ Stability rating & $\begin{array}{c}\text { Unit weight, } \gamma \\
\left(\mathrm{kN} / \mathrm{m}^{3}\right)\end{array}$ & $\begin{array}{c}\text { Effective } \\
\text { friction angle, }\end{array}$ & $\begin{array}{c}\text { Effective } \\
\text { cohesion, } c^{\prime} \\
(\mathrm{kPa})\end{array}$ & $\begin{array}{c}{ }^{2} \text { Total shear } \\
\text { strength, , at } 3 \mathrm{~m} \\
(\mathrm{kPa})\end{array}$ \\
\hline \hline Poor & 20 & $15^{\circ}$ & 30 & 46 \\
Fair & 20 & $25^{\circ}$ & 40 & 68 \\
Varies & 20 & $30^{\circ}$ & 55 & 90 \\
Good & 20 & $35^{\circ}$ & 70 & 112 \\
\hline \hline
\end{tabular}

'Stability ratings are based on assessments by Radbruch (1969).

${ }^{2}$ Total shear strength, $\tau$, is roughly equivalent to $+c$ '.

resulting displacements range from $0.7 \mathrm{~cm}$ to an effective maximum of $100 \mathrm{~cm}$ (displacements exceeded $100 \mathrm{~cm}$ for so few grid cells that those cells can be disregarded). The Newmark displacements calculated here are strongly skewed toward low values (mean displacement is $5.5 \mathrm{~cm}$ ) and are arrayed in an approximately logarithmic frequency distribution (not shown).

To prepare the final map depicting earthquake-triggered landslide hazards for the Oakland-Piedmont-Berkeley area (pl. 4), we normalized the calculated values of Newmark displacement $\left(D_{N}\right)$ by the maximum value $(100 \mathrm{~cm})$ and divided them into the following six categories of relative hazard: low (0.007-0.019), moderately low (0.02-0.049), moderate (0.05-0.099), moderately high (0.10-0.199), high (0.20-0.499), and very high (0.50-1.00). The arbitrary boundaries of the intervals are appropriate for mapping results of the analysis because Newmark displacement is a relative index of slope performance rather than an estimate of actual ground deformation (Jibson and others, 1998). To faithfully represent the near-logarithmic distribution of the normalized Newmark displacements, we chose hazard intervals that increase with increasing $D_{N}$ in an approximately log-normal progression. Accordingly, the hazard intervals at the low end of the $D_{N}$ range are sufficiently narrow to reveal significant spatial patterns (pl. 4) in the abundant low values of Newmark displacement that evenly spaced intervals would have concealed. Several of these patterns closely correlate with geologic map units (see ch. 5, this report). Bedrock lithology, thus, is a major control on landslide likelihood in the Oakland-Berkeley study area for all three failure scenarios prepared for this report (see chs. 2 and 3).

\section{Acknowledgments}

R.J. Pike further revised, amended, and edited an early revised draft of this chapter.

\section{References Cited}

Bartlett, S.F., and Youd, T.L., 1995, Empirical prediction of liquefaction-induced lateral spread: Journal of Geotechnical Engineering, v. 121, no. 4, p. 316-329.

California Geological Survey, 2003a, State of California seismic hazard zones - Oakland East and part of Las Trampas Ridge quadrangles: California Geological Survey Seismic Hazard Zones Map, scale 1:24,000 [http://gmw. consrv.ca.gov/shmp/download/pdf/ozn_oake.pdf].

California Geological Survey, 2003b, State of California seismic hazard zones-Richmond quadrangle: California Geological Survey Seismic Hazard Zones Map, scale 1:24,000 [http://gmw.consrv.ca.gov/shmp/download/pdf/ ozn_rich.pdf].

California Geological Survey, 2003c, State of California seismic hazard zones-Briones Valley quadrangle: California Geological Survey Seismic Hazard Zones Map, scale 1:24,000 [http://gmw.consrv.ca.gov/shmp/download/ pdf/ozn_briov.pdf].

California Geological Survey, 2003d, State of California seismic hazard zones-San Leandro quadrangle: California Geological Survey Seismic Hazard Zones Map, scale 1:24,000 [http://gmw.consrv.ca.gov/shmp/download/pdf/ ozn_slea.pdf].

California Geological Survey, 2003e, State of California seismic hazard zones - Oakland West quadrangle: California Geological Survey Seismic Hazard Zones Map, scale 1:24,000 [http://gmw.consrv.ca.gov/shmp/download/ pdf/ozn_oakw.pdf].

Cole, W.F., Marcum, D.R., Shires, P.O., and Clark, B.R., 1998, Analysis of earthquake-reactivated landslides in the epicentral region, Central Santa Cruz Mountains, California, in Keefer, D.K., ed., The Loma Prieta, California, Earthquake of October 17, 1989-Landslides: U.S. Geological Survey Professional Paper 1551-C, p. 165-185 [http://pubs.usgs.gov/pp/pp1551/pp1551c/]. 
Cooper-Clark and Associates, 1975, Preliminary map of landslide deposits in Santa Cruz County, California: City of Santa Cruz, Planning Department, scale 1:62,500.

Graymer, R.W., Jones, D.L., and Brabb, E.E., 1996, Preliminary geologic map emphasizing bedrock formations in Alameda County, California—a digital database: U.S. Geological Survey Open-File Report 96-252 [http://pubs. usgs.gov/of/1996/of96-252/].

Harp, E.L., and Jibson, R.W., 1995, Inventory of landslides triggered by the 1994 Northridge, California earthquake: U.S. Geological Survey Open-File Report 95-213, 17 p. [http://pubs.usgs.gov/of/1995/ofr-95-0213/].

Jibson, R.W., 1993, Predicting earthquake-induced landslide displacements using Newmark's sliding block analysis: Washington, D.C., Transportation Research Board, National Research Council, Transportation Research Record 1411, p. 9-17.

Jibson, R.W., Harp, E.L., and Michael, J.A., 1998, A method for producing digital probabilistic seismic landslide hazard maps - an example from the Los Angeles, California area: U.S. Geological Survey Open-File Report 98-113, 17 p., 2 pl. [http://pubs.usgs.gov/of/1998/ofr-98-113/].

Keefer, D.K., 1984, Landslides caused by earthquakes: Geological Society of America Bulletin, v. 95, p. 406-421.

Keefer, D.K., ed., 1998, The Loma Prieta, California, Earthquake of October 17, 1989-Landslides: U.S. Geological Survey Professional Paper 1551-C, 185 p. [http://pubs.usgs.gov/pp/pp1551/pp1551c/].

Keefer, D.K., Griggs, G.B., and Harp, E.L., 1998, Large landslides near the San Andreas Fault in the Summit Ridge area, Santa Cruz Mountains, California, in Keefer, D.K., ed., The Loma Prieta, California, Earthquake of October 17, 1989—Landslides: U.S. Geological Survey Professional Paper 1551-C, p. 71-128 [http://pubs.usgs. gov/pp/pp1551/pp1551c/].

Miles, S.B., and Ho, C.L., 1999, Rigorous landslide hazard zonation using Newmark's method and stochastic ground motion simulation: Soil Dynamics and Earthquake Engineering, v. 18, no. 4, p. 305-323.

Miles, S.B., and Keefer, D.K., 2000, Evaluation of seismic slope-performance models using a regional case study: Environmental \& Engineering Geoscience, v. 6, no. 1, p. 25-39.

Miles, S.B., and Keefer, D.K., 2001a, Seismic landslide hazard for the city of Berkeley, California: U.S. Geological Survey Miscellaneous Field Studies Map MF-2378 [http:// pubs.usgs.gov/mf/2001/2378/].

Miles, S.B., and Keefer, D.K., 2001b, Seismic landslide hazard for the cities of Oakland and Piedmont, California: U.S. Geological Survey Miscellaneous Field Studies Map MF-2379 [http://pubs.usgs.gov/mf/2001/2379/].

Miles, S.B., Keefer, D.K., and Nyerges, T.L., 2000, A case study in GIS-based environmental model validation using earthquake-induced landslide hazard, in Heuvelink, G.B.M., and Lemmens, M.J.P.M., eds., Fourth International Symposium on Spatial Accuracy Assessment in Natural Resources and Environmental Sciences [Proceedings]: Amsterdam, Delft University Press, p. 481-493.

Newmark, N.M., 1965, Effects of earthquakes on dams and embankments: Geotechnique, v. 15, p. 139-160.

Radbruch, D.H., 1969, Areal and engineering geology of the Oakland East quadrangle, California: U.S. Geological Survey Geologic Quadrangle Map GQ-769, scale 1:24,000.

Wieczorek, G.F., Wilson, R.C., and Harp., E.L., 1985, Map showing slope stability during earthquakes in San Mateo County, California: U.S. Geological Survey Miscellaneous Investigations Series Map I-1257-E, scale 1:62,500.

Wilson, R.C., 1993, Relation of Arias intensity to magnitude and distance in California: U.S. Geological Open-File Report 93-556, $41 \mathrm{p}$.

Wilson, R.C., and Keefer, D.K., 1983, Dynamic analysis of a slope failure from the 6 August, 1979 Coyote Lake, California, earthquake: Seismological Society of America Bulletin, v. 73, no. 3, p. 863-877.

Wilson, R.C., and Keefer, D.K., 1985, Predicting areal limits of earthquake-induced landsliding, in Ziony, J.I., ed., Evaluating earthquake hazards in the Los Angeles region - an earth-science perspective: U.S. Geological Survey Professional Paper 1360, p. 317-345, 492-494.

Wilson, R.I., Wiegers, M.O., McCrink, T.P., Haydon, W.D., and McMillan, J.R., 2003, Earthquake-induced landslide zones in the Oakland East 7.5-minute quadrangle, Alameda County, California, in Seismic hazard zone report for the Oakland East 7.5-minute quadrangle, Alameda County, California: California Geological Survey Seismic Hazard Zone Report 080, p. 26-48, plate 2.1 [http://gmw.consrv. ca.gov/shmp/download/evalrpt/oake_eval.pdf].

Working Group on California Earthquake Probabilities, 1999, Earthquake probabilities in the San Francisco Bay region, 2000 to 2030 - a summary of findings: U.S. Geological Survey Open-File Report 99-517, 60 p. [http://geopubs. wr.usgs.gov/open-file/of99-517/].

Youd, T.L., and Hoose, S.N., 1978, Historic ground failures in northern California triggered by earthquakes: U.S. Geological Survey Professional Paper 993, 177 p. 


\title{
Chapter 5
}

\section{Synthesis of Landslide-Hazard Scenarios Modeled for the Oakland-Berkeley Area, Northern California}

\author{
By Richard J. Pike
}

\section{Introduction}

Each of the three scenarios modeled in this report brings a different perspective to understanding the geographical extent of slope failure in the San Francisco Bay region, exemplified here by four maps of landslide susceptibility for the OaklandBerkeley area. Chapter 1 explains how long- or short-duration rainfall induces, respectively, the large, deep-seated landslides treated in chapter 2 (pl. 1) or the small, shallow landslides (many of which mobilize as debris flows) modeled in chapter 3 (pls. 2 and 3). By contrast, the role of meteorology in earthquake-triggered landsliding (ch. 4, pl. 4) is indirect. In two respects, the resulting maps are alike: steep upland and hilly lowland terrain is more predisposed to failure than flat lowland, and landslide likelihood differs according to rock type. Within the terrain and geologic units that contain most of the observed landslides, however, susceptibility varies locally, according to differences in process that distinguish the three scenarios. Because the susceptibility patterns depicted on the maps differ among the three scenarios, the maps complement rather than duplicate one another; as a result, all three scenarios must be considered in order to fully delineate the potential hazard.

This synthesis chapter first describes some of the similarities and differences among the four susceptibility maps by presenting 15 sites for comparison and offering some general observations. The sites described are open to alternative interpretations, not all of which can be explored here; many more similarities and differences would emerge from an exhaustive comparison by GIS, also outside the scope of this report. The chapter then addresses the relation of landslide susceptibility to landslide risk in the study area and examines the potential for refining susceptibility models, for example, by estimating the extent of debris-flow run-out and incorporating slope orientation or aspect (compass direction) and other topographic attributes. The chapter closes with a summary of conditions that lead to landsliding under the three scenarios, as well as brief discussions of model accuracy, applications to regional planning and public safety, requirements for improved susceptibility mapping, and the prospects of further advances through new technologies.

Differences among susceptibility maps were identified by visual inspection. The maps were compared with each other, wherever possible at the same scale (for example, the map on plate 1 is compared with the one on plate 2 rather than on plate 3 ), and with maps of geology and topography. Fifteen sites are shown on figure 5-1, six of which are illustrated in figures 5-2 through 5-4. All rock formations cited are described on the geologic map of Graymer (2000), on which chapter 2 and the map on plate 1 are partly based. Details of the physical characteristics of the various materials, which may be helpful in evaluating local susceptibility to landsliding, can be found in Ellen and Wentworth (1995) and references therein (see also, Wentworth, 1997). Details of local topography are shown on published U.S. Geological Survey 1:24,000-scale quadrangle maps; see index to quadrangles on figure 5-1. The topography also is available as digital elevation models (DEMs), digital line graphs (DLGs), and digital raster graphics (DRGs) from the U.S. Geological Survey (see http://bard. wr.usgs.gov/). Except where specified, such characterizations of terrain as "steep" or "gentle" derive from visual inspection of 1:24,000-scale contour maps only and are sufficient for this summary; the few values of average slope cited in this chapter were computed from DEMs at 30-m spatial resolution. Related information on seismicity in the San Francisco Bay region is available from the U.S. Geological Survey (http://earthquake.usgs.gov/regional/nca/maps/index.php), the Association of Bay Area Governments (http://www.abag. org/bayarea/eqmaps/), and the California Geological Survey (http://www.consrv.ca.gov/CGS/geologic_hazards/ earthquakes/index.htm).

\section{Susceptibility to Deep-Seated Land- sliding versus Shallow Landsliding Induced by Rainfall, as Depicted on the Maps on Plates 1 and 2, Respec- tively}

Contrasting patterns of modeled susceptibility arise from differences in controls on the two modes of rainfall-induced landsliding. In the case of large, deep, slow-moving failures driven by gradually rising groundwater levels or pore-water pressure (ch. 2, pl. 1), the controlling factors mainly are lithol- 


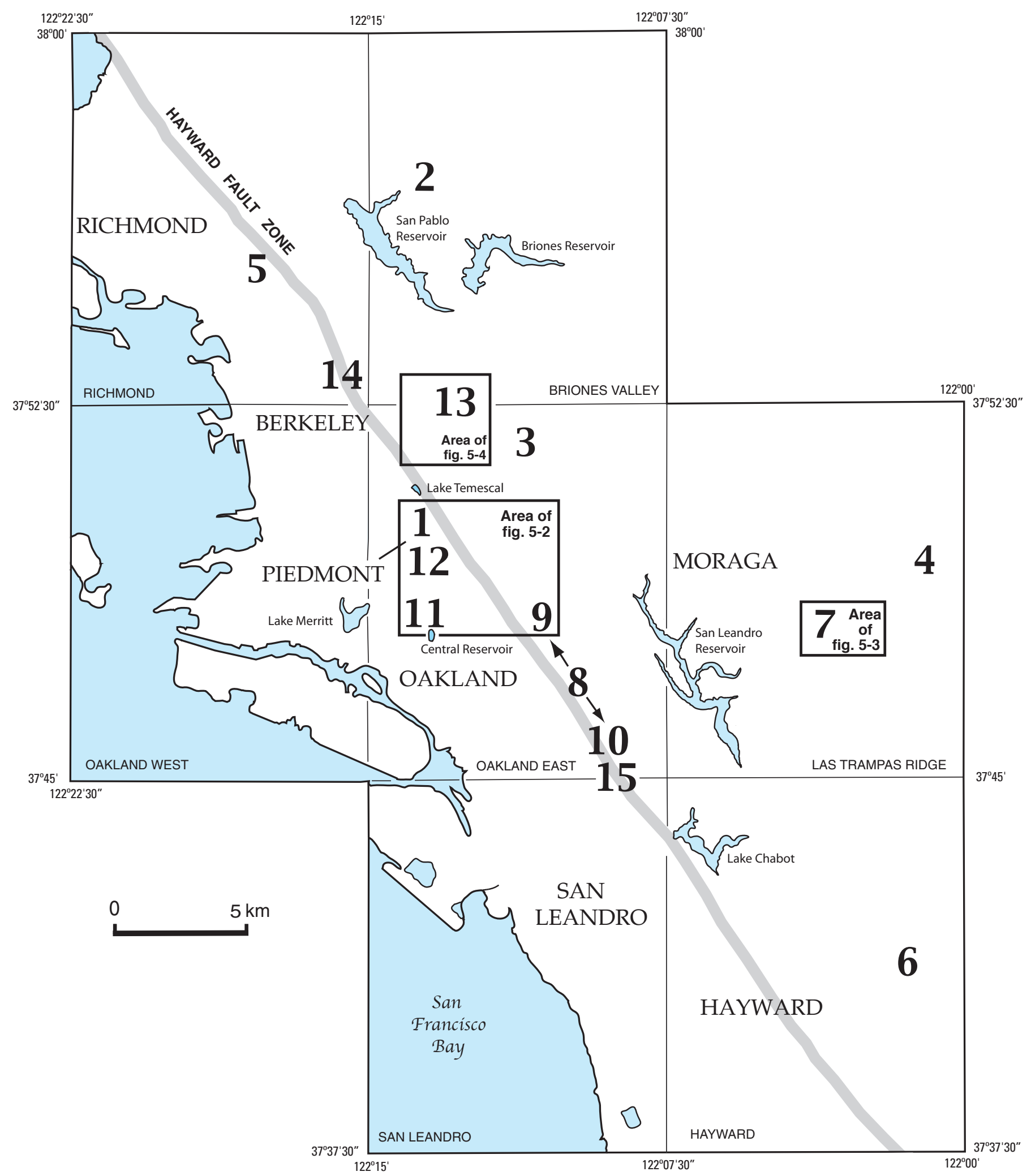

Figure 5-1. Index map showing locations of 15 comparison sites that illustrate similarities and (or) differences between landslide-susceptibility maps on plates $1,2,3$, and 4 . Also shown are locations of geographic features mentioned in this chapter, $7.5^{\prime}$ quadrangles in study area, and areas of figures 5-2, 5-3, and 5-4. Sites 1, 8 (northern part), 9, 11, and 12 are depicted on figure 5-2; site 7, on figure 5-3; and site 13, on figure 5-4. 
ogy and topography. In the case of source areas of shallow landslides triggered by intense, short-duration rainfall (ch. 3 , pl. 2), the main factors are topography and rapidly rising pore-water pressure within colluvium.

Many localities predicted to be susceptible to deep landsliding are less likely to fail by shallow landsliding. One example is the gently sloping terrain on soft, commonly sheared and weathered rocks of the Franciscan Complex mélange (unit KJfm, fig. 5-2), which border the Hayward Fault Zone around Lake Temescal in Oakland and Piedmont (fig. 5-1, site 1). A more conspicuous example is the steep terrain carved into Eocene shales and claystones northeast of San Pablo Reservoir (fig. 5-1, site 2); the map on plate 2 suggests that most of this area is unlikely to host shallow landslides despite its evident steepness, possibly reflecting a high fracture density that allows rapid and deep drainage of surface water through the rocks (K.M. Schmidt, oral commun., 2003). Another area of high susceptibility in the map on plate 1, northwest of the town of Moraga (fig. 5-1, site 3), contains many of the same rock units shown in fig. $5-4$; this area in a gently sloping valley underlain by nonmarine siltstones and claystones of the Siesta Formation (unit Tst) is classified in the "most stable" category of susceptibility to shallow landsliding (pl. 2). A fourth area of high likelihood of deep-seated landsliding, located south of San Ramon Valley (fig. 5-1, site 4), coincides with fault-bounded outcrops assigned provisionally (Graymer, 2000) to the resistant Hambre Sandstone and Neroly Sandstone units; these areas are mapped in the "most stable" category of susceptibility to shallow landsliding (pl. 2) and contain only minor areas of higher susceptibility that, again, may reflect locally steep slopes.

The circumstances described above are reversed in other places in the greater Oakland-Berkeley area: some localities are predicted to be highly prone to shallow landsliding (pl. 2) but to be of moderate to low susceptibility to deeper, larger failures (pl. 1). A minor but conspicuous example in the town of El Cerrito (fig. 5-1, site 5) is a small area of steep hills on a fault-bounded sliver of the Franciscan Complex mélange; the area is mapped as relatively resistant to deepseated failure (pl. 1), contrasting with areas of higher susceptibility of that same unit to deep failure elsewhere along the Hayward Fault Zone. Another example is a narrow band of moderate to high susceptibility to shallow landsliding (pl. 2) that flanks Palomares Creek west of Castro Valley (fig. 5-1, site 6); this area is a steep east-facing ridge developed on a resistant unit: Kcv, the unnamed sandstone, conglomerate, and shale of the Castro Valley area of Graymer (2000), which is not prone to deep-seated landsliding (pl. 1) but slopes $35^{\circ}$ and, thus, would appear to be likely to host shallow failures. Recent storms that might test the model for susceptibility to shallow landsliding (pl. 2) yielded equivocal results in this area: eight debris flows that were generated by the January 1982 storm mobilized within $1,200 \mathrm{~m}$ of the ridge but none directly on it (Wieczorek and others, 1988; Ellen and others, 1997); the February 1998 storm triggered one debris flow on the ridge and three small shallow landslides at the crest or foot of the ridge (Coe and others, 2004).

A third type of contrast between the modeled susceptibility shown on the two maps involves uniformly steep terrain, all of which is shown as highly prone to shallow failure but differs irregularly in the amount and certainty of area likely to be subject to deeper failure. A conspicuous example on the map on plate 1 is centered on a strip of ridged topography about $8 \mathrm{~km}$ by $1 \mathrm{~km}$ (fig. 5-1, site 7; see also, fig. $5-3)$. This area of relatively low susceptibility to deep-seated failure is underlain by a sequence of four thin sandstone subunits (the D, E, F, and G members, all of Wagner, 1978) of the Briones Sandstone (units Tbd, Tbe, Tbf, Tbg, fig. 5-3), as well as by the Neroly Sandstone (unit Tn, fig. 5-3). These rocks are modeled as being much less vulnerable to deeper landslides than the surrounding clay-rich lithology that also underlies the ridged topography, the unnamed sedimentary and volcanic rocks unit (Tus, fig. 5-3), comprising mudstone, sandstone, conglomerate, limestone, and trace amounts of volcanic rocks. This difference is absent on the map on plate 2 , on which all six units are predicted to be susceptible to shallow landsliding, evidently reflecting the high emphasis on topography in the model used to create the map on plate 2.

\section{Susceptibility to Earthquake-Triggered Landsliding versus Shallow Landslid- ing Induced by Rainfall, as Depicted on the Maps on Plates 4 and 3, Respectively}

Similarities and differences between the two 1:24,000-scale maps on plates 3 and 4 vary in complex ways with topography, bedrock lithology, (presumed) moisture content, and proximity to the Hayward Fault Zone. Areas of predicted high and low susceptibility to earthquake-generated landslides commonly are found in close juxtaposition on the same map, and their boundaries can be sharp, partly the consequence of contrasts in the materials units used to compute the model resulting in plate 4 (ch. 4 ; see also, Ellen and Wentworth, 1995).

One of the largest areas that is modeled as unlikely to fail in an earthquake (ch. 4) on the map on plate 4 lies east of the Highway 580/13 interchange immediately adjacent to the Hayward Fault Zone (fig. 1, sites 8 and 9; see also, fig. 5-2); however, most of this area is shown as highly susceptible to shallow rainfall-triggered landslides (ch. 3) on the map on plate 3. The hard igneous bedrock, a keratophyre (unit Jsv, fig. 5-2) previously mapped as the Leona Rhyolite, resists destabilization by seismic shaking but forms steep slopes that are prone to shallow landsliding. In contrast, smaller areas of gentle slope immediately north and south (fig. 5-1, sites 9 
and 10 , respectively) of this outcrop of keratophyre are underlain by weaker materials - serpentinite (unit sp, fig. 5-2) and, to a lesser extent, old alluvial fan deposits (unit Qpoaf, fig. $5-2$ ), respectively - that are predicted as likely to fail during an earthquake but unlikely to host shallow landslides.

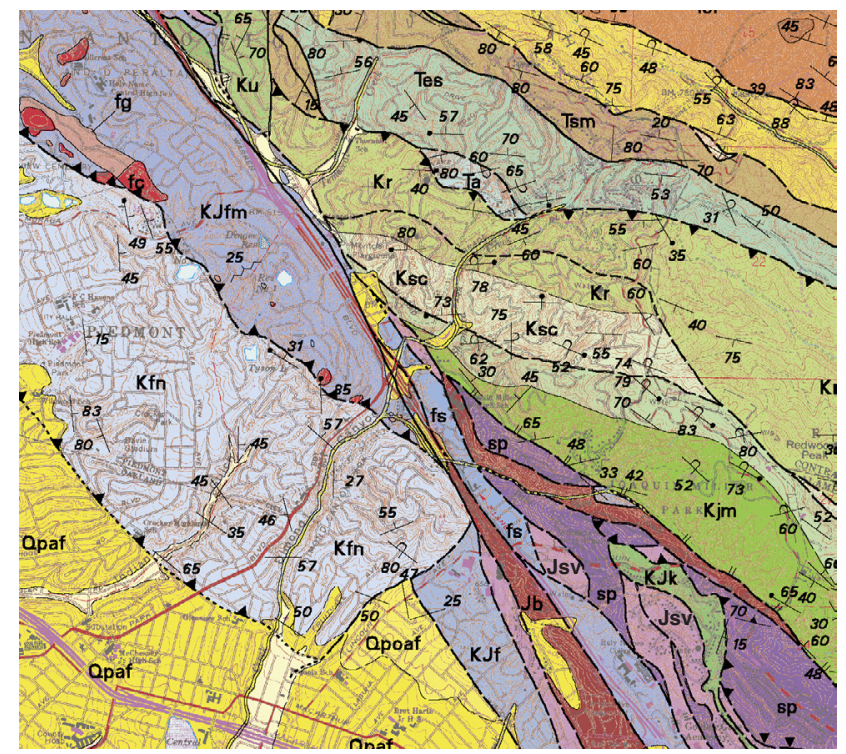

A

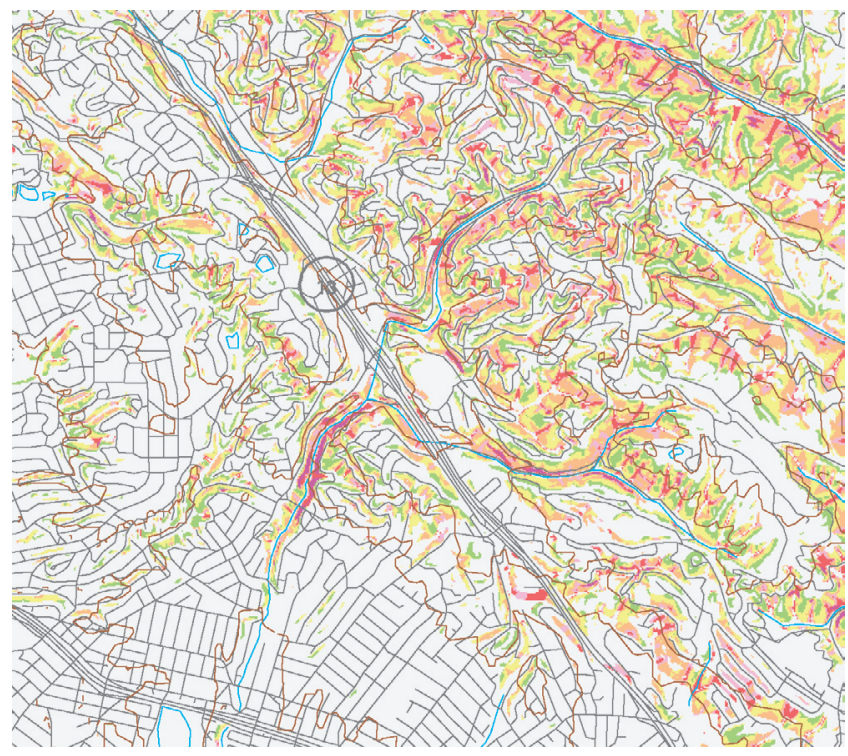

\section{C}

The broad expanse of low hills to the east and north of Lake Merritt, west of the Hayward Fault Zone in the cities of Oakland and Piedmont, offers a different example of the varying agreement between the maps on plates 3 and 4. An area of moderately sloping terrain (fig. 5-1, site

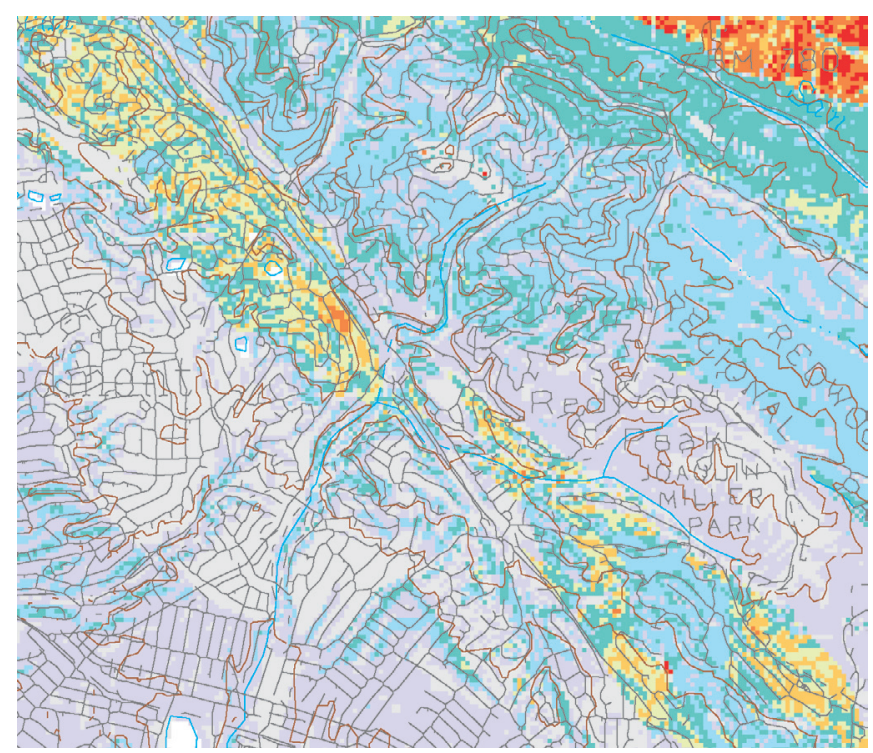

B

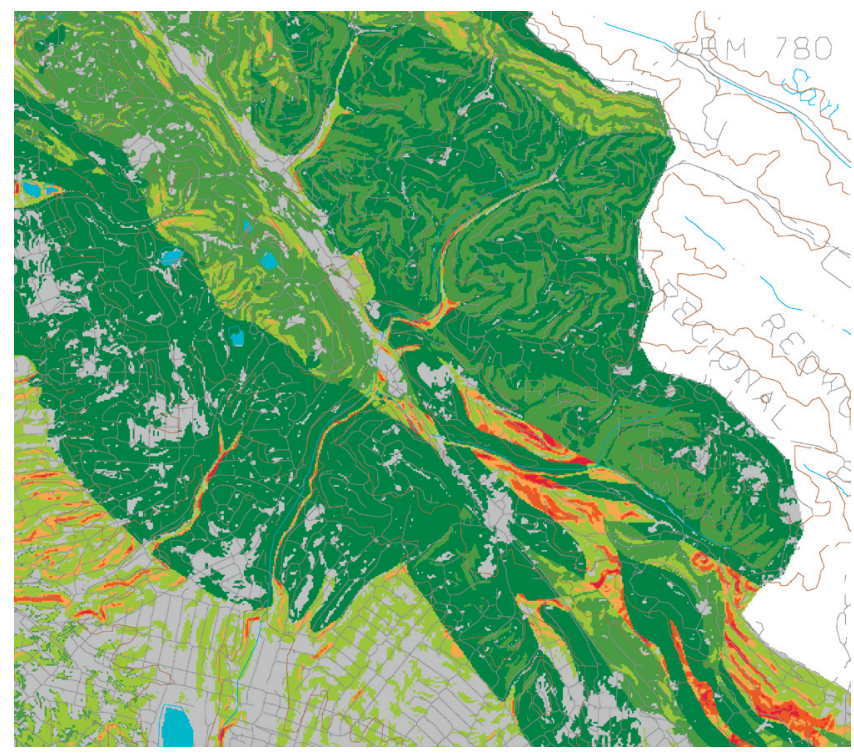

D

Figure 5-2. Maps showing areas of comparison sites 1, 8 (northern part), 9, 11, and 12, which illustrate similarities and differences between landslide-susceptibility maps on plates 1,2, and 4. Same area is covered in all four figures (A-D); width is about $5.8 \mathrm{~km}$; see figure 5-1 for location. A, Oakland-area geology, extracted from Graymer (2000). Relevant map units discussed in this chapter (see Graymer, 2000, for complete map-unit descriptions): Qpaf, alluvial fan and fluvial deposits; Qpoaf, older alluvial fan deposits; Kfn, sandstone of the Novato Quarry terrane of Blake and others (1984); KJfm, Franciscan Complex mélange; Jsv, keratophyre and quartz keratophyre; sp, serpentinite. See Graymer (2000) for map symbol explanation. B, Susceptibility to deep-seated landsliding, extracted from map on plate 1; susceptibility ranges from lowest (gray) to highest (red). C, Susceptibility to shallow landsliding, extracted from map on plate 2; susceptibility ranges from lowest (gray) to highest (purple). D, Susceptibility to earthquake-triggered landsliding, extracted from map on plate 4; susceptibility ranges from lowest (dark green) to highest (red). 
11) developed on the (poorly cemented) alluvial fan and fluvial deposits (unit Qpaf, fig. 5-2) is modeled as somewhat more likely to fail under seismic shaking (pl. 4) than an area immediately adjacent to it (fig. 5-1, site 12) that is underlain by the (resistant) sandstone of the Novato Quarry terrane of Blake and others (1987) (unit Kfn, fig. 5-2); however, the steeper slopes developed on both of these materi-
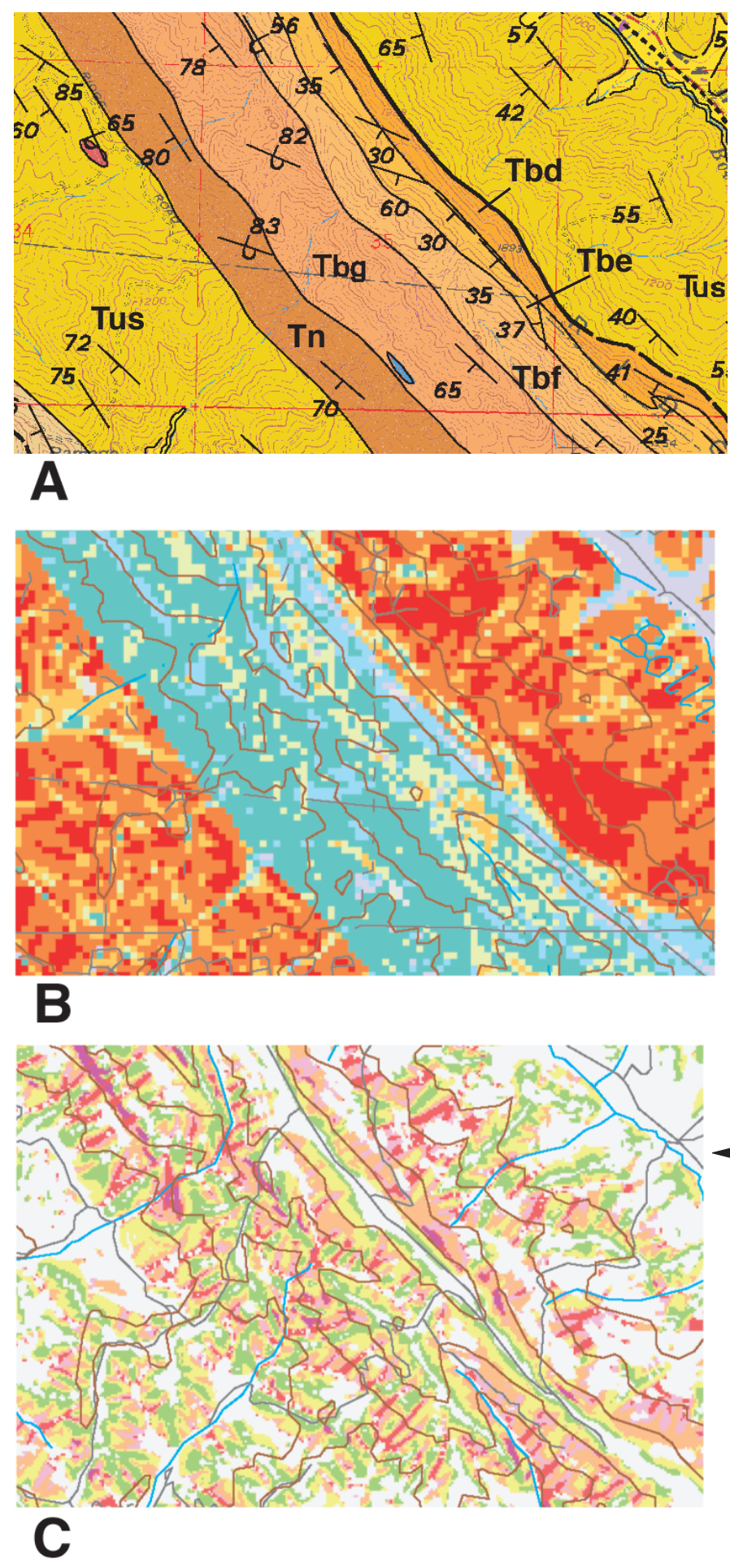

als are mapped as equally susceptible to shallow landsliding induced by rainfall (pl. 3).

The most conspicuous area of predicted high susceptibility to earthquake-triggered landsliding (fig. 5-1, site 13; fig. 5-4) also may be unstable under rainfall conditions that lead to shallow landsliding. The modeled susceptibilities to the two destabilizing processes in this area, however, do not correspond exactly. Whereas terrain underlain by intensely fractured basalt and andesite flows of the Moraga Formation (unit Tmb, fig. 5-4) and by clay-rich sedimentary rocks of the Orinda Formation (unit Tor, fig. 5-4) is predicted to be among the areas most likely to fail in an earthquake (the latter somewhat less than the former), adjacent terrain underlain by the Claremont chert of Graymer (2000) (unit Tcc, fig. 5-4) - arguably a more resistant unit (see, for example, ch. 2, fig. 2-2) - appears to be among the least susceptible. In contrast, the map on plate 3 indicates that, although all three units are prone to shallow landsliding in severe rainstorms (probably a consequence of the steep ridges developed across much of the area, which average $17^{\circ}$ ground slope at $30-\mathrm{m}$ resolution), the steeper Moraga Formation $\left(19^{\circ}\right.$ average slope $)$ and the Claremont chert of Graymer (2000) (20 average slope) are somewhat more susceptible (the latter slightly less than the former) than the gentler Orinda Formation $\left(15^{\circ}\right.$ average slope). The Claremont chert of Graymer (2000), thus, appears to behave least consistently across the two landslide-triggering processes.

\section{Susceptibility to Deep-Seated Land- sliding versus Earthquake-Triggered Landsliding, as Depicted on the Maps on Plates 1 and 4, Respectively}

The area showing the likelihood of earthquake-induced landsliding (ch. 4) modeled on the 1:24,000-scale map on plate 4 is much smaller than that showing the likelihood of deep-seated landsliding (ch. 2) modeled on the 1:50,000-scale map on plate 1. Also, the differences between these two maps,

Figure 5-3. Maps showing area of comparison site 7, which illustrates similarities and differences between landslide-susceptibility maps on plates 1 and 2. Same area is covered in all three figures $(\mathrm{A}-\mathrm{C})$; width is about $3.1 \mathrm{~km}$; see figure 5-1 for location. A, Oaklandarea geology, extracted from Graymer (2000). Relevant map units discussed in this chapter (see Graymer, 2000, for complete map-unit descriptions): Tus, unnamed sedimentary and volcanic rocks; Tn, Neroly Sandstone; Tbd, Tbe, Tbf, and Tbg, the D, E, F, and G members, all of Wagner (1978), of the Briones Sandstone. See Graymer (2000) for map symbol explanation. B, Susceptibility to deep-seated landsliding, extracted from map on plate 1; susceptibility ranges from lowest (gray) to highest (red). C, Susceptibility to shallow landsliding, extracted from map on plate 2; susceptibility ranges from lowest (gray) to highest (purple). 


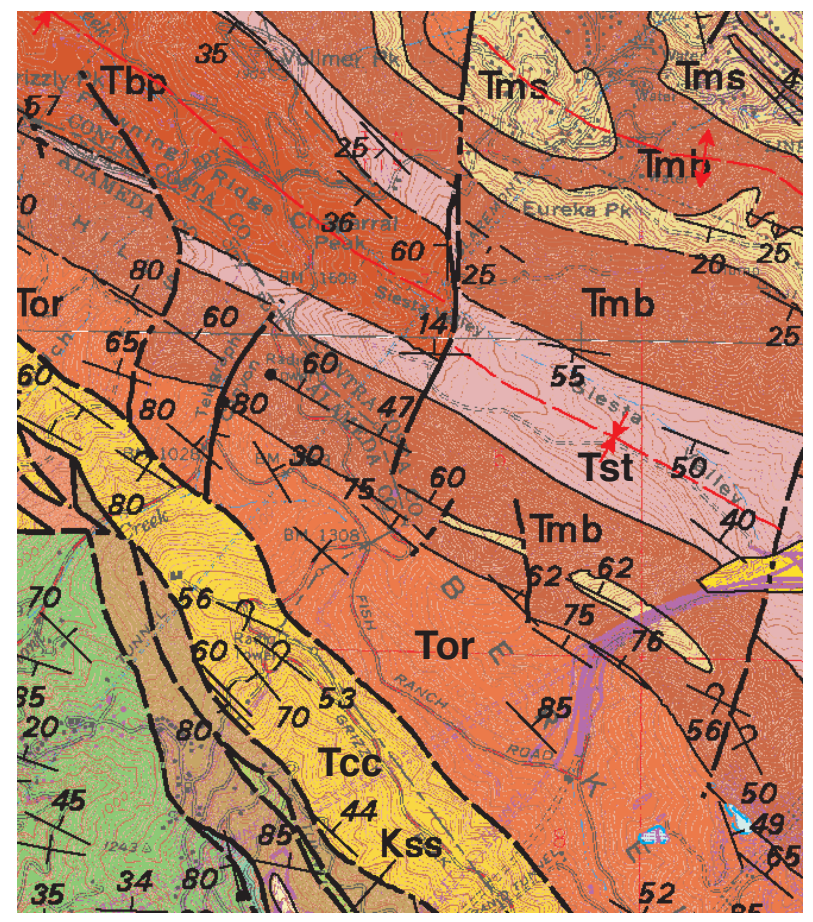

A

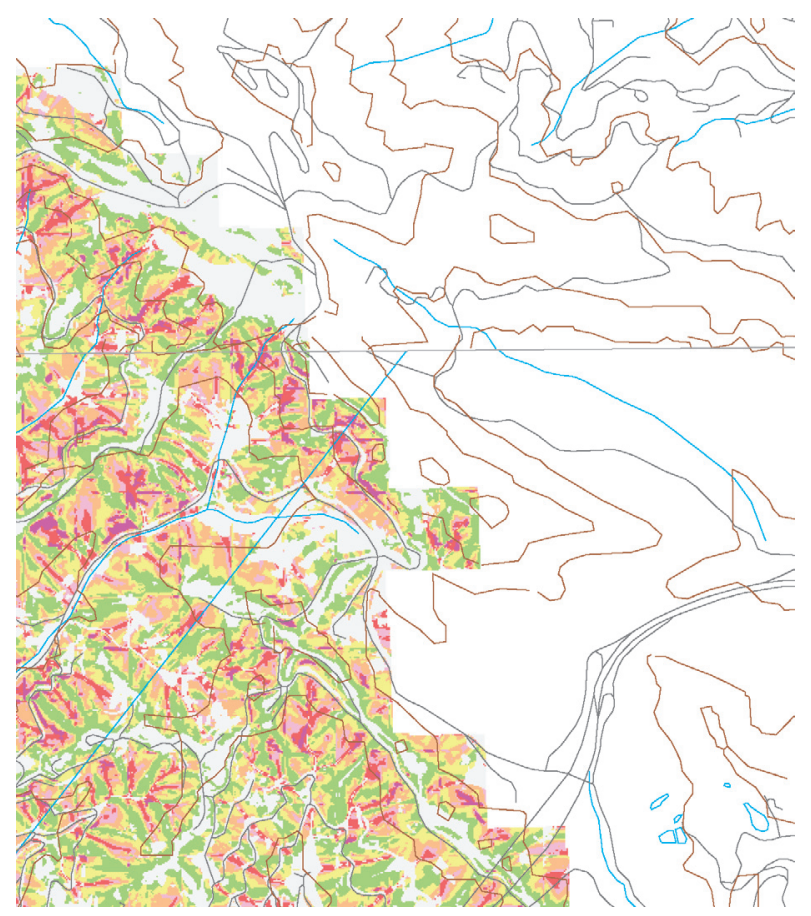

C

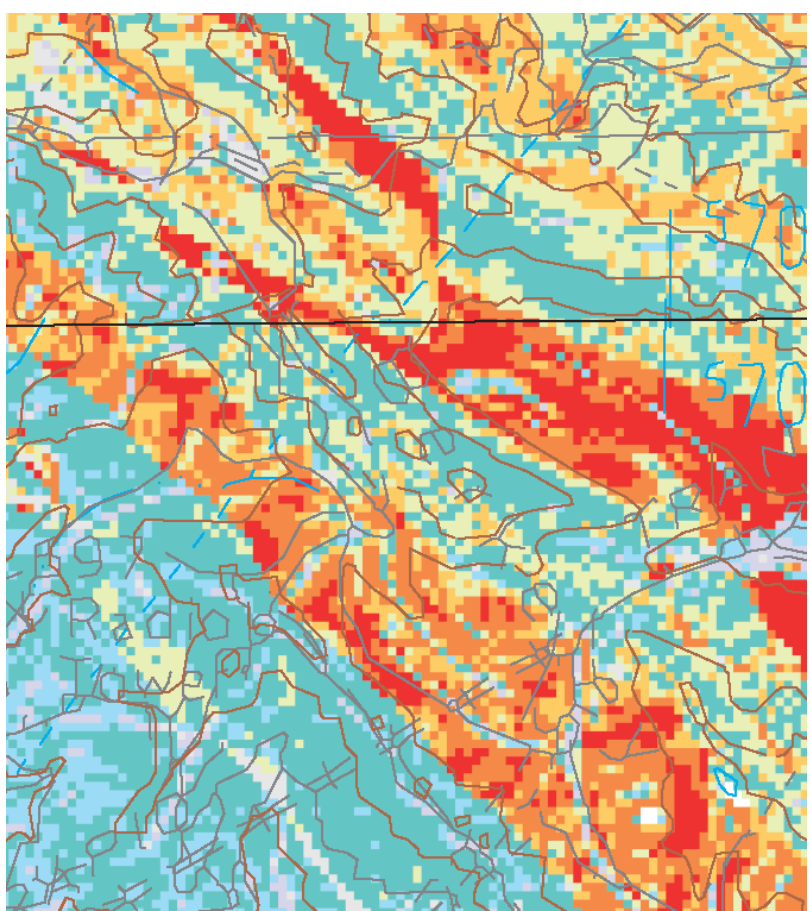

B

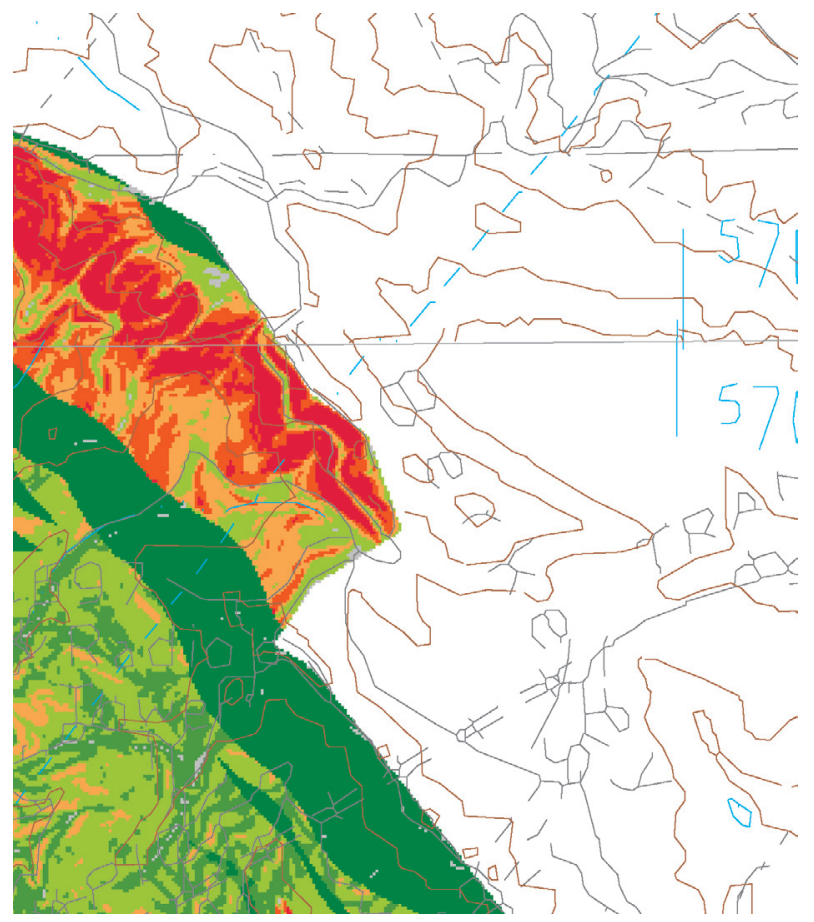

D

Figure 5-4. Maps showing area of comparison site 13, which illustrates similarities and differences between landslide-susceptibility maps on plates 1, 3, and 4. Same area is covered in all four figures (A-D); width is about $3.3 \mathrm{~km}$; see figure 5-1 for location. A, 0aklandarea geology, extracted from Graymer (2000). Relevant map units discussed in this chapter (see Graymer, 2000, for complete map-unit descriptions): Tbp, Bald Peak Basalt; Tst, Siesta Formation; Tmb, Moraga Formation; Tor, Orinda Formation; Tcc, Claremont chert of Graymer (2000). See Graymer (2000) for map symbol explanation. B, Susceptibility to deep-seated landsliding, extracted from map on plate 1; susceptibility ranges from lowest (gray) to highest (red). C, Susceptibility to shallow landsliding, extracted from map on plate 3; susceptibility ranges from lowest (gray) to highest (purple). D, Susceptibility to earthquake-triggered landsliding, extracted from map on plate 4; susceptibility ranges from lowest (dark green) to highest (red). 
where they overlap, are more subdued than the strong contrasts between either map and the maps on plates 2 and 3 (ch. 3 ), because a deep-seated landslide can result from an earthquake but not from shallow failure. Deep-seated landsliding on the maps on both plates 1 and 4 primarily reflects underlying lithology, (presumed) subsurface moisture, and moderate slopes, whereas the likelihood of shallow landsliding (pls. 2 and 3) requires steep slopes and a supply of colluvium.

Areas underlain by the Franciscan Complex mélange (unit $\mathrm{KJfm}$ ) exemplify the muted range of local similarities and differences in susceptibility between these two maps (pls. 1 and 4), which appear to agree more often than they disagree. For example, most exposures of Franciscan Complex mélange, such as the areas east of Lake Merritt along the Hayward Fault Zone (fig. 5-2), are modeled as being of low to moderate susceptibility on both maps, depending on configuration of the topography. However, an exposure of unit KJfm (fig. 5-2), located in the city of Berkeley west of the Hayward Fault Zone (fig. 5-1, site 14), is mapped as having a moderately low susceptibility to earthquake-induced landsliding on the map on plate 4 but as having a moderate to high susceptibility on the map on plate 1 . The influence of slope gradient reverses this relation in other locations; for example, the steepest slopes in Franciscan Complex mélange along Highway 24 west of the Hayward Fault Zone are modeled as highly susceptible to earthquake-induced failure on the map on plate 4 but not to deep-seated landsliding on the map on plate 1.

The large area of diverse lithology described in the last section (fig. 5-1, site 13) contains several differences between the two maps (pls. 1 and 4). Three of the formations consist of sedimentary rocks: on both maps the Claremont chert of Graymer (2000) (unit Tcc, fig. 5-4) is assigned a low likelihood of failure, whereas the Orinda Formation (unit Tor, fig. 5-4) is assigned a range of moderate to high susceptibility values; the (adjacent) Siesta Formation (unit Tst, fig. 5.4), by contrast, is among the most likely to host deep-seated landslides (pl. 1) but is only moderately susceptible to earthquake-triggered landslides (pl. 4). Two other units in this area consist of volcanic rocks: lava flows of both the Moraga Formation (unit Tmb, fig. 5-4) and the Bald Peak Basalt (unit Tbp, fig. 5-4) are mapped as moderately susceptible to deep-seated landsliding (pl. 1); however, susceptibility to earthquake-triggered failure is predicted to be moderate to high for the Moraga Formation but low for the Bald Peak Basalt (pl. 4). No ready explanation emerges for the inconsistent behavior modeled for these weathered volcanic rocks (largely basalts). Both units have clayey mantles that are severely expansive, prone to shrink/ swell activity under seasonally contrasting conditions of soil moisture (Ellen and Wentworth, 1995, p. 84-85). Because the scenario depicted on the map on plate 4 assumes ground saturation, an expansive soil would increase susceptibility in the event of an earthquake during a wet winter.

A few small areas on the two maps (pls. 1 and 4) contrast more sharply. Several minor northwest-striking outcrops of Franciscan Complex rock types are modeled as having high susceptibility to earthquake-triggered landsliding (pl. 4) but having very low to moderate susceptibility to deep-seated failure (pl. 1). Examples include a cluster of gabbro exposures northwest of Lake Chabot in the southern extremity of the map on plate 4 (fig. 5-1, site 15); a second cluster of small exposures of serpentinite (unit sp, fig. 5-2) is situated just west of Highway 13 and north of Holy Names College (fig. 5-1, site 9). All of these areas are in steep topography close to the Hayward Fault Zone, which evidently is the reason for their high susceptibility to earthquake-triggered landsliding (pl. 4).

\section{From Landslide Susceptibility to Land- slide Risk}

Grading (modifying) hillsides for roads, residential dwellings, and other human uses of the land can change the level of susceptibility modeled herein for undeveloped slopes. The resulting consequences for landslide prediction vary considerably, can be drastic, and are not easily incorporated into susceptibility calculations. If a graded slope is well engineered, its likelihood of failure actually may decrease rather than increase. Wherever the built environment coincides with potentially unstable terrain, however, landslide susceptibility becomes transformed into a parameter of landslide risk: a measure of the likelihood of harm to life and property. Judging the relevance of the scenarios modeled in this report to estimating the risk to public safety requires, among other things, information on how the land is occupied (van Westen and others, 2006). Although most of the area mapped as susceptible to landsliding on plates 1 through 4 is undeveloped forest and rangeland that is unlikely to be converted to residential or other human uses, a number of locales that are potentially prone to instability have been graded for development. The spatial extent of the overlap between land occupied by residential housing and area modeled as susceptible to deep-seated landsliding was measured by GIS and is shown in table 2-3 (ch. 2). The coincidence is substantial and ranges from 23 to 32 percent for residential land in hillside terrain that has moderate to high values of the susceptibility index in plate $1(0.20-0.30)$.

A similar GIS analysis of land use has not been carried out for the predicted areas of rainfall-induced shallow landsliding or of earthquake-triggered landsliding; however, visual inspection of the map on plate 2 and an unpublished, 1:50,000-scale U.S. Geological Survey experimental map of 1995 land use in the San Francisco Bay region computed from the 100-m-resolution data of Perkins and Chuaqui (1996) reveals that much of the area inferred to be likely to host shallow landslides includes tracts of residential housing. The overlap includes some level ground at the foot of hillslopes, as well as hilly and upland terrain. Debris-flow damage to occupied dwellings is common in such areas, both in hills bordering the East Bay Plain and within inland valleys and their enclosing uplands (Coe and Godt, 2001; Coe and others, 
2004). The potential danger to residential areas indicated by the initiation sites shown on the maps on plates 2 and 3 is compounded by the subsequent flow of mobilized debris down hillslopes and onto valley floors (not modeled on these maps).

Much of the densely developed hilly terrain bordering the Hayward Fault Zone is modeled as at-risk from earthquake-triggered landsliding. Visual overlay of the unpublished 1:50,000-scale land-use experimental map (cited above) with a 1:50,000-scale reduction of the map on plate 4 reveals that several built-up areas are coincident with highsusceptibility terrain. Among these are residential neighborhoods southwest of Tilden Regional Park (fig. 5-1, site 13) on steeper slopes of the Orinda and Moraga Formations (units Tor and Tmb, respectively, fig. 5-4); housing subdivisions located near Arroyo Viejo (fig. 5-1, site 10), especially those on alluvial fan deposits; and residences on steep serpentinite (unit sp, fig. 5-2), between Skyline Boulevard and Holy Names College (fig. 5-1, site 9). Parts of the extensive hilly area of Oakland that is approximately bounded by Lake Merritt, Lake Temescal, the Central Reservoir, and steeper hills to the east (fig. 5-1, sites 1 and 12; see also, fig. 5-2) are also predicted to be at risk; in this area, earthquake-triggered landslide susceptibility modeled in chapter 4 ranges from low to very high, the latter values concentrated along the steep banks of old west-flowing drainages in alluvial fan and fluvial deposits (unit Qpaf, fig. 5-2) and in sandstone of the Novato Quarry terrane of Blake and others (1984) (unit Kfn, fig. 5-2).

\section{Toward Refinement of Landslide-Susceptibility Models}

From the various kinds of spatial data now available, many different susceptibility maps could have been generated for the landslide scenarios addressed in this report. For example, the maps on plates 2 and 3 model only the source areas of shallow landsliding on steep slopes; a much larger area of potential hazard lies downslope of each initiation site in the path taken by run-out of the mobilized material, a difficult-to-model phenomenon (Mark and Ellen, 1995; Iverson, 1997; Bertolo and Wieczorek, 2005) that is not addressed in this report. In addition, each of the three computer models in chapters 2 through 4 could have been modified or elaborated to more accurately predict susceptibility; other GIS-implemented factors that are worth consideration include distance to nearest road, vegetation type, dip direction of rock strata, and parameters of terrain geometry generated from DEMs of higher quality than are currently available. To that end, three simple parameters that might improve the values of susceptibility shown on the maps on plates 1 through 4 and that can be derived readily from DEMs - slope aspect, elevation, and local relief - are briefly considered here.

Beaty (1956) first quantified the relation between slope aspect (orientation, or "exposure") and landsliding in the San
Francisco Bay region. He found that 78 of $112(70 \%)$ small landslides east of the city of Oakland, not identified by type but sufficiently recent "that the upper scarp had not yet been obscured by vegetation," occupied northwest- to northeastfacing slopes. In contrast, a similar analysis of slope orientation by Bonilla (1960) determined that most of the 42 shallow landslides he sampled in the San Francisco South 7.5' quadrangle, about $20 \mathrm{~km}$ west of Oakland, occupied southwestfacing slopes. Turnbull (1976) found that the aspect of 582 earth flows located in and east of the southeast corner of the Hayward 7.5' quadrangle was distributed evenly, except in north- and northeast-facing directions (the relative deficiency in these directions reflects a dearth of north- and northeastfacing topography, not fewer landslides).

To clarify the conflicting results of these three studies, measurements of aspect were calculated from DEMs for two large, disparate sets of landslide data in the Oakland-Berkeley study area (Pike and Sobieszczyk, 2003). The first were the 6,714 pre-1970 deep-seated landslide deposits described in chapter 2, consisting of 116,360 30-m grid cells. The second were the approximate source-area locations of 1,943 debris flows that formed in the 3-5 January 1982 storm (Wieczorek and others, 1988; Ellen and others, 1997), each represented by one $30-\mathrm{m}$ cell. Both sets of measurements (in percent of total observations by $10^{\circ}$ intervals) are skewed strongly to the southwest, but the skewness primarily reflects the many northeast- and southwest-facing slopes produced by the conspicuous fault-controlled northwest strike of the local topography (Bonilla, 1960). To remove this statistical bias, we normalized the two distributions of landslide aspect by the distribution for all susceptible slopes in the study area (those steeper than $3^{\circ}$ and above $75 \mathrm{~m}$ elevation); however, the resulting two distributions remain skewed (fig. 5-5), in different directions that are not related to topography. These directions, which reflect contrasting processes of landslide initiation, infer that any incorporation of hillside aspect into predictive models of slope instability for the San Francisco Bay region must be tailored to specific scenarios of landslide origin; two of these are described briefly in the following paragraphs.

Figure 5-5 shows that deep-seated landslides favor northeast- to east-northeast-facing slopes and are least frequent on south-facing slopes. The prevailing explanation for this observation was first proposed in the study area by Beaty (1956). South-southwest-facing slopes are exposed to afternoon sun at near-normal angles of incidence in the northern hemisphere and so retain little soil moisture, whereas north-northeast-facing slopes are more shaded, sustaining less evapotranspiration (Geiger, 1950, p. 215ff) and, thus, accumulating more, and deeper, moisture over extended periods. These are the conditions favorable to deep-seated failure triggered by prolonged rainfall or seismic shaking.

Such conditions are unlikely to have contributed to location of the shallow, rapidly mobilized 1982 debris flows, which are least abundant on north- to northeast-facing slopes and most abundant on (normalized) southeast-facing slopes. One explanation for the skewed orientation of debris flows in 
figure 5-5 is wind-driven rainfall from the southeast, which almost certainly delivers more moisture to exposed (in this area, south-facing) slopes than to sheltered (north-facing) slopes (Geiger, 1950, p. 246-247; Pike and Sobieszczyk, 2003, 2005). Bonilla (1960) had proposed this explanation, although not the local storm-wind direction, for shallow landslides in the San Francisco South quadrangle. The frequency distribution of debris flows shown on figure 5-5 is consistent with the overall average $135^{\circ}$ strike of local topography, which exposes the abundant southwest-facing slopes to the southerly winds that are characteristic of winter storms in the San Francisco Bay region, as well as with the $155^{\circ}$ median of 33 hourly measurements of wind direction during the January 1982 storm,

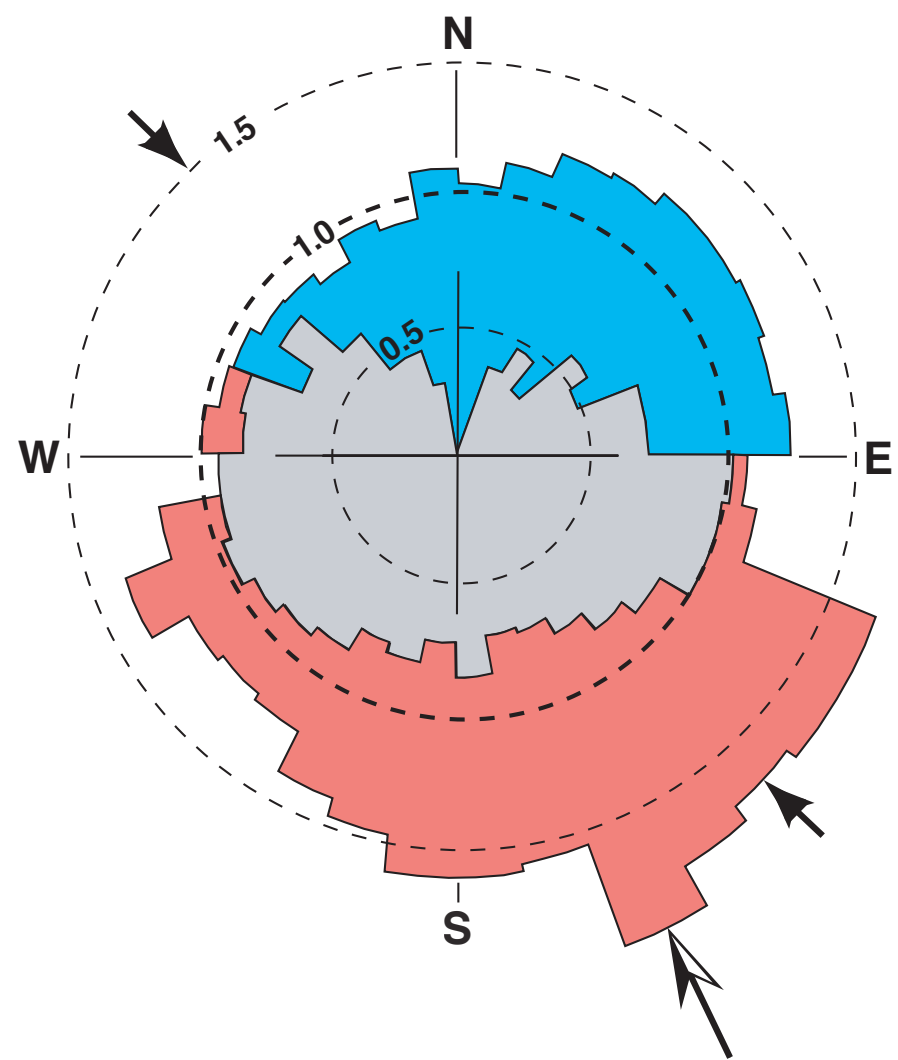

Figure 5-5. Contrasting frequency distributions of slope aspect (orientation, or "exposure") for two types of landslides in Oakland-Berkeley area. Landslide aspect, plotted in $10^{\circ}$ intervals as percentage of total number of observations, is normalized by aspect of topography, also in percentage of total observations. Uniform distribution (no preferred orientation) would lie entirely within heavy-dashed (middle) circle at $100 \%(1.0)$ of normalized aspect; inner and outer light-dashed circles mark $50 \%$ and $150 \%(0.5,1.5)$ of normalized aspect. Neither distribution is uniform, and each describes a different exposure. Old deep-seated landslides (blue and gray), plotted as 30-m grid cells on pre-1970 deposits, prefer northeast- to east-northeast-facing slopes. Debris flows from 3-5 January 1982 storm (red and gray), plotted as one cell per source area, favor southeast-facing slopes. Small paired arrows indicate strike of Hayward Fault Zone and dominant trend of local topography; large single arrow shows median wind direction during 1982 storm (see fig. 5-6). as recorded at nearby Oakland International Airport (fig. 5-6). The distribution of debris-flow aspect in the study area, the influence of wind-driven rainfall from the southeast, and such contributing explanations as aspect-related contrasts in vegetation type, are explored in detail by Pike and Sobieszczyk (2008).

Two parameters of the topographic relief that provides the setting for each landslide have some potential to improve susceptibility estimates: the likelihood of landsliding in the study area varies with both elevation above sea level and relative (local) relief, also partly a function of elevation. Rainfall tends to increase with elevation (ch. 1). In addition, most deep-seated landslides (ch. 2) are located at the comparatively high elevations of $100 \mathrm{~m}$ to $350 \mathrm{~m}$, and 20 percent of all elevations between $200 \mathrm{~m}$ and $350 \mathrm{~m}$ are on landslide deposits. The 1,943 debris flows from the 1982 storm also tended to initiate at high elevations; the mean height of $240 \pm 85 \mathrm{~m}$ for the source areas well exceeded the $145-\mathrm{m}$ mean of the study area. The correlation of landslide susceptibility with elevation is inexact, however. Sites of predicted high susceptibility to both deepseated and shallow landsliding (pls. 1 and 2), for example, lie above the East Bay Plain but otherwise appear to be distributed at random throughout the elevation range. Similarly,

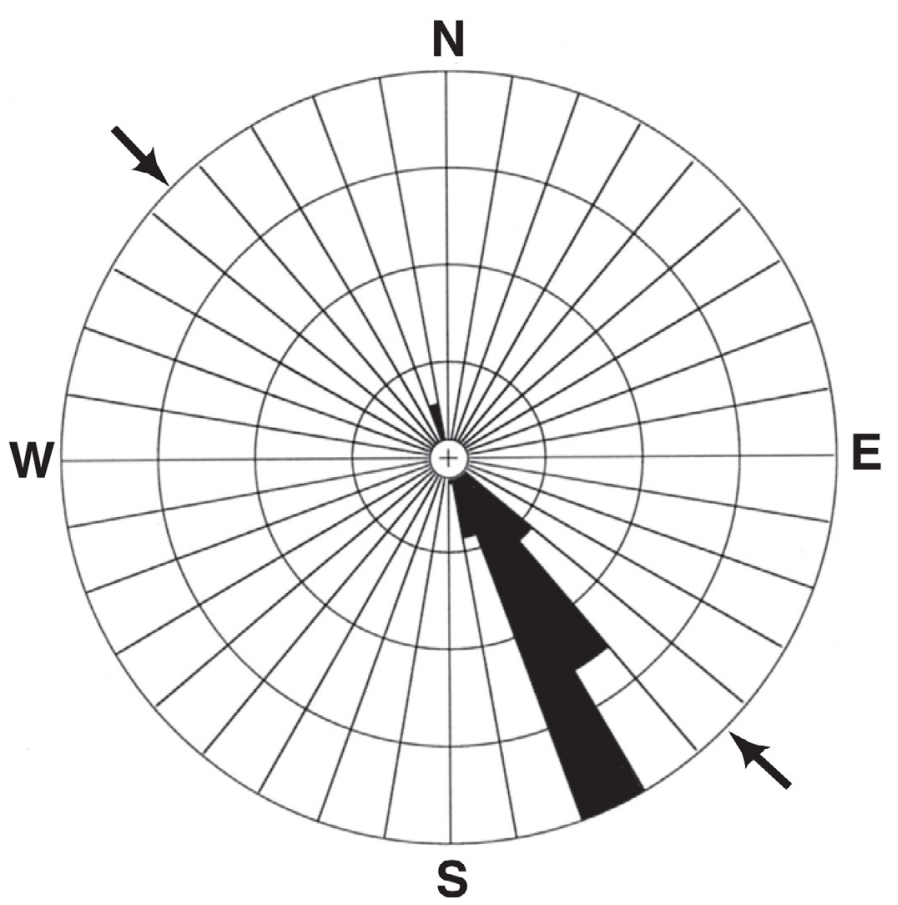

Figure 5-6. Frequency distribution of wind direction recorded hourly at Oakland International Airport over 34-hour duration of 3-5 January 1982 storm, plotted in $10^{\circ}$ intervals as percentage of 33 total observations. Measured average hourly wind speed, $10 \mathrm{~m} / \mathrm{sec}$; maximum, 15 $\mathrm{m} / \mathrm{sec}$. Prevailing wind direction is south-southeast; median, $155^{\circ}$; vector mean, $145^{\circ} \pm 10^{\circ}$; maximum percent frequency $\left(150^{\circ}-160^{\circ}\right.$ modal interval), 42.4. Compare with normalized distribution of debris-flow aspect in figure 5-5. Paired arrows indicate strike of Hayward Fault Zone and dominant trend of local topography. 
visual comparison of the 1982 debris-flow source areas with the predicted areas of high susceptibility to shallow landsliding (pl. 2) indicates only general agreement.

Further GIS-based analysis shows that the shallow landsliding modeled on the map on plate 2 correlates more closely with relative relief than with elevation. Relative relief (elev $v_{\max }-e l e v_{\min }$, computed from a 30-m DEM on 200 $\mathrm{m} \times 200 \mathrm{~m}$ grid cells) exceeds $135 \mathrm{~m}$ for all large, continuous tracts of terrain predicted as unstable to shallow landsliding (values of stability index below -2.7 on the map on plate 2), whereas all terrain having less than $35 \mathrm{~m}$ of relative relief lies in the most stable areas.

Two key attributes that favor shallow landsliding in the study area, steep slopes and topographic concavities (see, for example, discussion of equation 1 in ch. 3 ), are common to the higher relief terrain. Because subtle concavities in San Francisco Bay region hillsides are not well defined on DEMs extracted from contour maps at scales of 1:24,000 and smaller (Reneau and Dietrich, 1987), relative relief may carry more predictive power than slope curvature measured from the DEMs currently available for large areas. For example, only 35 percent of the debris-flow sources in the January 1982 storm lie within locally concave (convergent) topography, as calculated on $90 \mathrm{~m} \times 90 \mathrm{~m}$ sample areas from a 30-m DEM; however, this percentage is scale dependent, falling to 28 percent for $300 \mathrm{~m} \times 300 \mathrm{~m}$ samples from a 100-m DEM regridded from a 30-m DEM but increasing for finer scale data. For example, Coe and Godt (2001) mapped 531 debris flows from the February 1998 El Niño storm in and southeast of the Oakland-Berkeley study area. Their calculations on a 10-m DEM revealed that 44 percent of the landslides initiated on convergent topography. Field observations indicate that the actual percentage of debris flows that initiate on convergent topography in the hills of the San Francisco Bay region probably is higher (Reneau and Dietrich, 1987).

\section{Conclusion and Prospect}

The Oakland-Berkeley-area landslide susceptibility models discussed in this report refine earlier predictive work (San Francisco Bay Landslide Mapping Team, 1997), which showed that the multiple-scenario approach is essential to a spatial appraisal of the landslide hazard in the San Francisco Bay region. Many site characteristics act both independently and in concert to localize landsliding initiated by the three scenarios. The influences on landslide susceptibility exerted by soil moisture, bedrock lithology, soil-mantle properties, vegetative cover, slope geometry and orientation, and proximity to an active fault are not uniform and, most likely, not linear. Resulting patterns of potential instability, such as those depicted on the maps on plates 1 through 4, vary further according to the transient phenomenology of each initiating event. Storms and earthquakes differ locally and unpredictably in their intensity and do not generate similar effects uniformly across a region (see chs. 1 and 4). Table 5-1 summarizes the major relations interpreted among triggering events, site characteristics, and resulting landslides in the study area.

Despite their level of detail (5-m to 30-m grid spacing), the maps on plates 1 through 4 record only a broad-scale assessment of potential landslide locations. The spatial predictions modeled in chapters 2 through 4 also have margins of error not calculated here. Therefore, accuracy of the resulting maps, especially the certainty of prediction that high values of the stability indices will coincide with the locations of future landslides, is unknowable from available information. Increasingly common in exercises in susceptibility mapping are calculations that claim "model validation" (see, for example, Chung and Fabbri, 2003). The term "validation" is misleading (Oreskes, 1998; Miles, 2000), however, because it conveys the unqualified pass/fail connotation of unreliable/ reliable to the point of certainty, especially to government policymakers and the general public. In actuality, most socalled validations do not certify a susceptibility model in any absolute sense but, rather, are tests for a model's degree of internal consistency, and so they should be interpreted with caution. Only future storms or earthquakes - and documented inventories of landslides that moved at different times in the same area - can confirm or invalidate a spatial prediction of landsliding.

The maps and interpretations presented here can be applied to land-use planning and zoning, the drafting of building codes, and maintenance of public safety in the greater Oakland-Berkeley area. In addition to identifying possible locations of future landsliding under different failure-inducing scenarios, this report has emphasized factors that can refine the predictions shown on the maps on plates 1 through 4 . Rock and soil types, moisture content, and terrain configuration are major determinants of slope instability locally. Knowledge of the distribution of these and other site characteristics (for example, soil thickness or joint density in rocks) in specific areas may be helpful to planning officials and emergency preparedness and response personnel. Many data for developing a detailed awareness of local conditions are archived in geologic, topographic, and soil maps, as well as web sites and computer databases. This information is available from Federal, state, county, and municipal agencies, particularly the U.S. Geological Survey and the California Geological Survey, as well as from local soils engineers and consulting geologists in private practice.

Efforts toward a landslide-resistant environment for the San Francisco Bay region through susceptibility mapping do not end with the scenarios modeled in this report. Much work remains to narrow the uncertainties present in the maps on plates 1 through 4. Among the most urgent requirements are topographic data to replace currently available DEMs, which were extracted from map contours that predate much of the region's hillside development and, thus, do not accurately represent topography modified by cut-and-fill grading; high-resolution DEMs potentially are forthcoming from new 
Table 5-1. Summary of interpreted relations among landslide-triggering events, hillside conditions, and consequent types of failure. Decreasing relative order of importance of site characteristics in each category is speculative.

\begin{tabular}{|lll|}
\hline \multicolumn{1}{|c|}{ Initiating Scenario } & $\begin{array}{c}\text { Site Characteristics } \\
\text { Predisposed to Failure }\end{array}$ & $\begin{array}{c}\text { Resulting Types of } \\
\text { Landslides }\end{array}$ \\
\hline $\begin{array}{l}\text { Substantial and prolonged rainfall } \\
\text { over one season or successive } \\
\text { seasons }\end{array}$ & $\begin{array}{l}\text { High ground-water table, weak or } \\
\text { clay-rich bedrock, moderate to } \\
\text { steep slope, northeast-facing } \\
\text { slope orientation }\end{array}$ & $\begin{array}{l}\text { Large, deep earth slumps; rock } \\
\text { slumps; earth block slides; rock } \\
\text { block slides; earth flows }\end{array}$ \\
$\begin{array}{l}\text { Intense rainfall of relatively brief } \\
\text { duration, in one severe storm or a } \\
\text { rapid succession of storms }\end{array}$ & $\begin{array}{l}\text { Antecedent rainfall, steep slope } \\
\text { and thick colluvium, south-facing } \\
\text { slope orientation, lithology }\end{array}$ & $\begin{array}{l}\text { Small, shallow soil slips; debris } \\
\text { slides and earth flows that } \\
\text { mobilize into debris flows }\end{array}$ \\
Large earthquake & $\begin{array}{l}\text { Proximity to active fault, high } \\
\text { ground-water table, steep slope, } \\
\text { weak or clay-rich bedrock }\end{array}$ & $\begin{array}{l}\text { Rock falls and topples; disrupted } \\
\text { soil slides; deep-seated rock } \\
\text { slumps and block slides }\end{array}$ \\
\hline
\end{tabular}

technologies (Carter and others, 2003). Other needs include detailed geologic mapping (as opposed to reconnaissance mapping) at 1:24,000 scale, which would enable landslidesusceptibility modeling to be extended beyond the immediate San Francisco Bay region, and collection of data (for example, distance to nearest road) that reflect destabilization of the natural terrain in urban areas where large concentrations of inhabitants may be at risk from landslides (Pike and others, 2003). Also desirable are rainfall thresholds for deep-seated landsliding (see ch. 1), coupled with long-term predictions of major storms, the ENSO / El Niño phenomenon, and other climatic influences. In addition, the goal of earthquake prediction continues to be elusive; a satisfactory model for debris-flow runout remains to be developed for the San Francisco Bay region; the myriad debris flows and small landslides triggered by major rainstorms rarely are mapped or documented (Coe and others, 2004); and fully attributed landslide inventories have yet to be compiled for deep-seated failures (see ch. 2). Finally, GIS analysis of topographic aspect, relief, elevation, and other hillside properties (Pike and Sobieszczyk, 2008) may further refine the regional prediction of landsliding.

The maps on plates 1 through 4 foreshadow more flexible approaches to landslide-hazard modeling, whereby regional scenarios that are continuously updated by computer may be folded into a decision-support system guided by probabilistic risk assessment (PRA) (Vecchia, 2001). Mathematical tools, for example, could estimate in real time which areas are most likely to become unstable during the course of a major rainstorm, thereby enabling emergency-service managers to gauge the varied level of risk across the San Francisco Bay region and direct limited resources accordingly. A decisionsupport and PRA framework also could include a capability for early warning. Although single landslides that pose a rec- ognized threat are readily instrumented and monitored (Reid and LaHusen, 1998), this solution is impracticable over large areas; regional warning systems that are based on advanced technologies remain in their infancy (Sisson and others, 2001; Kienholz, 2003; Manunta and others, 2003; Hilley and others, 2004). Moreover, even the most sophisticated approaches to hazard modeling cannot incorporate all factors that affect predictions for such a complicated phenomenon as landsliding, where local site conditions must be linked with regional meteorological or seismic events that are themselves complex natural systems subject to stochastic variation (Haff, 1996; Wilcock and Iverson, 2003).

\section{Acknowledgments}

This chapter benefited from comments by K.M. Schmidt, R.W. Graymer, G.F. Wieczorek, and D.G. Howell. Steven Sobieszczyk provided technical support, and Jan Null of Golden Gate Weather Services kindly supplied hourly wind data for the January 1982 storm.

\section{References Cited}

Beaty, C.B., 1956, Landslides and slope exposure: Journal of Geology, v. 64, no. 1, p. 70-74.

Bertolo, Paola, and Wieczorek, G.F., 2005, Calibration of numerical models for small debris flows in Yosemite Valley, California: Natural Hazards and Earth System Sciences, v. 5, p. 993-2,001.

Blake, M.C., Jr., Howell, D.G., and Jayko, A.S., 1984, 
Tectonostratigraphic terranes of the San Francisco Bay region, in Blake, M.C., Jr., ed., Franciscan geology of northern California: Pacific Section, Society of Economic Paleontologists and Mineralogists, v. 43, p. 5-22.

Bonilla, M.G., 1960, Landslides in the San Francisco South quadrangle, California: U.S. Geological Survey Open-File Report 60-15, 43 p.

Carter, W.E., Shrestha, R.L., and Dietrich, W.E., 2003, National Center for Airborne Laser Mapping proposed: EOS, Transactions of the American Geophysical Union, v. 84, no. 30, p. 281, 285.

Chung, C.F., and Fabbri, A.G., 2003, Validation of spatial prediction models for landslide hazard mapping: Natural Hazards, v. 30, no. 3, p. 451-472.

Coe, J.A., and Godt, J.W., 2001, Debris flows triggered by the El Niño rainstorm of February 2-3, 1998, Walpert Ridge and vicinity, Alameda County, California: U.S. Geological Survey Miscellaneous Field Studies Map MF-2384, 22 p., 1:24,000 scale [http://pubs.usgs.gov/mf/2002/mf-2384/].

Coe, J.A., Godt, J.W., and Tachker, Pierre, 2004, Map showing recent (1997-98 El Niño) and historical landslides, Crow Creek and vicinity, Alameda and Contra Costa Counties, California: U.S. Geological Survey Scientific Investigations Map 2859, 15 p., 1:24,000 scale [http://pubs.usgs.gov/ $\operatorname{sim} / 2004 / 2859 /]$.

Ellen, S.D., Mark, R.K., Wieczorek, G.F., Wentworth, C.M., Ramsey, D.W., and May, T.E., 1997, Map showing principal debris-flow source areas in the San Francisco Bay region, California: U.S. Geological Survey Open-File Report 97-745-E [http://pubs.usgs.gov/of/1997/of 97-745/].

Ellen, S.D., and Wentworth, C.M., 1995, Hillside materials and slopes of the San Francisco Bay region, California: U.S. Geological Survey Professional Paper 1357, 215 p., scale 1:125,000.

Geiger, Rudolf, 1950, The climate near the ground [translation by M.N. Stewart and others of 2nd German ed., 1941]: Cambridge, Mass., Harvard University Press, 482 p.

Graymer, R.W., 2000, Geologic map and map database of the Oakland metropolitan area, Alameda, Contra Costa, and San Francisco Counties, California: U.S. Geological Survey Miscellaneous Field Studies Map MF-2342, 29 p., scale 1:50,000 [http://geopubs.wr.usgs.gov/map-mf/mf 2342/].

Haff, P.K., 1996, Limitations on predictive modeling in geomorphology, in Thorn, C.E., and Rhoads, B.L., eds., The scientific nature of geomorphology: New York, Wiley, p. 337-358.

Hilley, G.E., Bürgmann, Roland, Ferretti, Alessandro, Novali, Fabrizio, and Rocca, Fabio, 2004, Dynamics of slowmoving landslides from permanent scatterer analysis: Science, v. 304, no. 5679, p. 1,952-1,955.

Iverson, R.M., 1997, The physics of debris flows: Reviews of Geophysics, v. 35, no. 3, p. 245-296.

Kienholz, Hans, 2003, Early warning systems related to mountain hazards, in Zschau, Jochen, and Küppers, A.N., eds., Early warning systems for natural disaster reduction: Berlin Heidelberg, Springer, p. 555-564.
Manunta, Paolo, and 19 others, 2003, SLAM, a Service for Landslide Monitoring based on EO-data: European Space Agency [http://dup.esrin.esa.int/projects/summaryp52. asp; see also, http://earth.esa.int/workshops/fringe03/ participants/485/paper_paper_manunta_SLAM.pdf].

Mark, R.K., and Ellen, S.D., 1995, Statistical and simulation models for mapping debris-flow hazard, in Carrara, Alberto, and Guzzetti, Fausto, eds., Geographical information systems in assessing natural hazard: Dordrecht, Kluwer, p. 93-106.

Miles, S.B., 2000, Towards policy relevant environmental modeling - contextual validity and pragmatic models: U.S. Geological Survey Open-File Report 00-401, 20 p. [http:// geopubs.wr.usgs.gov/open-file/of00-401/].

Oreskes, Naomi, 1998, Evaluation (not validation) of quantitative models: Environmental Health Perspectives, v. 106 (Supplement 6), p. 1,453-1,460.

Perkins, J.B., and Chuaqui, Ben, 1996, Existing land use in 1995 — data for Bay area counties and cities: Oakland, Calif., Association of Bay Area Governments, 200 p.

Pike, R.J., Howell, D.G., and Graymer, R.W., 2003, Landslides and cities - an unwanted partnership, in Heiken, Grant, Fakundiny, Robert, and Sutter, J.F., eds., Earth science in the city - a reader: American Geophysical Union Special Publication 56, p. 187-254.

Pike, R.J., and Sobieszczyk, Steven, 2003, Process-modulated contrasts in slope exposure of landslides in the San Francisco Bay area, California [abs.]: EOS, Transactions of the American Geophysical Union, v. 83, no. 47 (Supplement), p. F557, no. H12D-0956 [http://www.agu. org/meetings/fm02/fm02-pdf/fm02_H12D.pdf].

Pike, R.J., and Sobieszczyk, Steven, 2005, San Francisco Bay area debris flows localized by wind-driven precipitation [abs.]: Geological Society of America, Abstracts with Programs, v. 37, no. 4, p. 78 [http://gsa.confex.com/ gsa/2005CD/finalprogram/abstract_85330.htm].

Pike, R.J., and Sobieszczyk, Steven, 2008, Soil slip/debris flow localized by site attributes and wind-driven rain in the San Francisco Bay region storm of January 1982: Geomorphology, v. 94, nos. 3-4, p. 290-313.

Reid, M.E., and LaHusen, R.G., 1998, Real-time monitoring of active landslides along highway 50, El Dorado County: California Geology, v. 51, no. 3, p. 17-20.

Reneau, S.L., and Dietrich,W.E. 1987, The importance of hollows in debris flow studies - examples from Marin County, California, in Costa, J.E., and Wiezcorek, G.F., eds., Debris flows/avalanches - process, recognition and mitigation: Reviews in Engineering Geology, v. 7, p. 165-180.

San Francisco Bay Landslide Mapping Team, 1997, San Francisco Bay region, California, landslide folio: U.S. Geological Survey Open-File Report 97-745 [http://pubs. usgs.gov/of/1997/of 97-745/].

Sisson, T.W., Vallance, J.W., and Pringle, P.T., 2001, Progress made in understanding Mount Rainier's hazards: EOS, Transactions of the American Geophysical Union, v. 82, no. 
9, p. 113, 118-120.

Turnbull, R.W., 1976, Engineering geology of the Eden Canyon area near Castro Valley, Alameda County, California: Stanford, Calif., Stanford University, M.S. thesis, $107 \mathrm{p}$.

van Westen, C.J., van Asch, T.W.J., and Soeters, Robert, 2006, Landslide hazard and risk zonation - why is it still so difficult?: Bulletin of Engineering Geology and the Environment, v. 65, no. 2, p. 167-184.

Vecchia, A.V., compiler, 2001, A unified approach to probabilistic risk assessments for earthquakes, floods, landslides, and volcanoes; Proceedings of a multidisciplinary workshop held in Golden, Colo., November 16-17, 1999: U.S. Geological Survey Open-File Report 01-324 [http:// nd.water.usgs.gov/pubs/ofr/ofr01324/].

Wagner, J.R., 1978, Late Cenozoic history of the Coast Ranges east of San Francisco Bay: Berkeley, University of California, Ph.D. dissertation, 160 p., 12 plates.
Wentworth, C.M., compiler, 1997, General distribution of geologic materials in the San Francisco Bay region, California - a digital map database: U.S. Geological Survey Open-File Report 97-744, 24 p., scale 1:125,000 [http://pubs.usgs.gov/of/1997/of97-744/].

Wieczorek, G.F., Harp, E.L., Mark, R.K., and Bhattacharyya, A.K., 1988, Debris flows and other landslides in San Mateo, Santa Cruz, Contra Costa, Alameda, Napa, Solano, Sonoma, Lake, and Yolo Counties, and factors influencing debris-flow distribution, in Ellen, S.D., and Wieczorek, G.F., eds., Landslides, floods, and marine effects of the storm of January 3-5, 1982, in the San Francisco Bay region, California: U.S. Geological Survey Professional Paper 1434, p. 133-161 [http://pubs.usgs.gov/ pp/1988/1434/].

Wilcock, P.R., and Iverson, R.M., eds., 2003, Prediction in geomorphology: Washington, D.C., American Geophysical Union, Geophysical Monograph Series, v. 135, 256 p. 